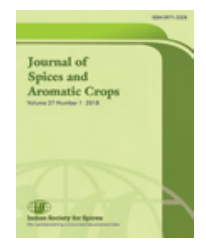

Performance, diversity analysis and character association of black pepper (Piper nigrum L.) accessions in the high altitude of Idukki district, Kerala

T T Preethy*, T S Aswathy, T Sathyan, M K Dhanya \& M Murugan

Cardamom Research Station, Kerala Agricultural University,

Pampadumpara-685 556, Idukki, Kerala.

*E-mail: anpreeththottamkara@gmail.com

Received 03 July 2017; Revised 18 February 2018; Accepted 26 March 2018

\begin{abstract}
The experiment was conducted to evaluate black pepper accessions for growth parameters, yield attributing characters and yield. Out of the ten accessions tested, Karimunda recorded the highest fresh $(1.61 \mathrm{~kg})$ and dry $(508.7 \mathrm{~g})$ yield of berries plant ${ }^{-1}$. Fresh weight showed significant positive genotypic correlation to dry weight and while negative correlated to 100 berry volume, 100 berry weight and number of berries spike ${ }^{-1}$. Hence, selection based on number of berries spike ${ }^{-1}$, 100 berry volume and 100 berry weight may not lead to the high yielding black pepper variety. The results showed that Karimunda is the most suitable black pepper variety for high altitude areas of Idukki district.
\end{abstract}

Keywords: black pepper, field evaluation, variability, yield

\section{Introduction}

Black pepper, Piper nigrum L., referred as the 'King of spices' is the most important spice in the world. Indian pepper fetches a premium price in major international markets due to its preference and intrinsic quality (Thomas 2010). In India, Kerala is famous for black pepper cultivation and export. Idukki and Wayanad are the major pepper growing districts which together contribute $90 \%$ of the Kerala production. There exists considerable variation for yield among black pepper cultivars (Ravindran \& Babu 1994). Idukki has maximum genetic diversity of black pepper. Most of the pepper farmers in the Idukki district are cultivating a minimum of five cultivars.
Every traditional pepper-growing tract has its own popular cultivar. Selection of cultivars for prevailing agroclimatic conditions is important for higher productivity. The diverse climatic and soil conditions in a state like Kerala necessitates the identification and popularization of location specific varieties for the enhancement of productivity of pepper (Prasannakumari et al. 2001). The performance of black pepper varieties varies significantly in plains and high ranges owing to the difference in environmental conditions of these two regions. For evolving high yielding varieties of any crop, knowledge on the relationship between yield and yield attributing characters as well as vegetative characters is essential. Therefore, the present study was initiated with the objective of 
evaluating the performance, character association and variability studies of the released varieties as well as promising selections of black pepper.

\section{Materials and methods}

The experiment was conducted as a part of All India Coordinated Research Project on Spices at Cardamom Research Station, Kerala Agricultural University, Pampadumpara, Idukki during 2010-2017 (7 years). Vines of ten high yielding accessions of black pepper were collected from Panniyur Research Station (HB 20052, PRS 88), Horticultural Research and Extension Station, Sirsi (Acc no. 53, Acc. no. 106), Horticultural Research Station, Yercaud (Acc no. 33, Acc. No. 57), IISR, Kozhikode (C1090, HP 39) and planted along with checks (Panniyur 1 and Karimunda) in a randomized block design with three replications at a spacing of $2 \times 2 \mathrm{~m}$. Agronomical practices were followed as per the package of practices of Kerala Agricultural University. Observations were recorded on various yield components for three cropping seasons. The pooled data for three years (2014-17) were subjected to statistical analysis. The simple phenotypic correlation coefficient was estimated using the formula suggested by Al-jibouri et al. (1958).

\section{Results and discussion}

\section{Performance of different cultivars}

All the black pepper accessions under test, differed significantly for vegetative characters like vine column height, leaf length, leaf width and internodal length (Tables 1). Vine column height recorded highest for Acc 57 which is on par with CL 1090. Acc 33 showed highest leaf length and leaf width followed by Panniyur 1 . Karimunda recorded lowest leaf length and leaf width.

All the yield and yield attributing characters showed significant difference among the accessions both at 1\% and 5\% level (Table.3). This indicates the presence of wide variability in accessions for these characters. Karimunda recorded highest fresh weight and dry weight of berries which is statistically on par with Panniyur 1 and HB 20052. Most of the yield attributing characters was high in Panniyur 1 except volume of 100 berries. Even though Karimunda was the best performed accession for the last three years, the yield attributing characters were not that much comparable with high yielding accessions except number of berries spike ${ }^{-1}$. However, according to Deka et al. (2016), Karimunda recorded higher number of laterals with more spread and higher number of spikes compared to the other varieties. Ibrahim et al. $(1985 ; 1987)$ have reported that spike yield and spike number in black pepper as important traits contributing for yield forwhich straight selection can be practiced for improvement. It may be the reason for high yielding nature of Karimunda.

Variance components, heritability and genetic advance

The estimates of genotypic variance $(\mathrm{GV})$ ranged between 0.03-2958.02 and phenotypic variance (PV) 0.18-21930.38. The phenotypic and genotypic variances were very far to each other and this shows the high influence of environment on morphological traits. Phenotypic coefficients of variation (PCV) ranged between 1.39-68.90; and genotypic coefficients of variation (GCV) between 1.0125.30 (Table 3). The PCV values were relatively higher than the GCV values for all the parameters indicating environmental influence on the expression of the traits [11]. However, GCV values were near to PCV values for characters like 100 berry volume, vine column height, leaf width, internodal length. Such differences indicate very low environment variance for the phenotypic expression of these characters. Heritability $\left(h^{2}\right)$ values ranged between $13.48 \%$ for dry weight to $95.63 \%$ for vine column height. The genetic advance as a percentage of the mean (GAM) also ranged from 1.51 for 100 berry volume to 40.00 for spike length. The combined estimation of heritability and genetic advance gives the response of a character to selection. Characters like spike length, vine column height, leaf width and internodal length was showed high heritability and high genetic advance. This indicates the suitability of these characters for selection due to additive gene action. The influence of environment to the characters governed by additive gene action is very less. 
Table 1. Pooled analysis data (2012-15) on vegetative characters

\begin{tabular}{lcccc}
\hline Accession & $\begin{array}{c}\text { Vine columnheight } \\
(\mathrm{cm})\end{array}$ & $\begin{array}{c}\text { Leaf length } \\
(\mathrm{cm})\end{array}$ & $\begin{array}{c}\text { Leaf width } \\
(\mathrm{cm})\end{array}$ & $\begin{array}{c}\text { Internodal length } \\
(\mathrm{cm})\end{array}$ \\
\hline Acc 106 & $233.2^{\mathrm{f}}$ & $16.3^{\mathrm{d}}$ & $8.5^{\mathrm{ef}}$ & $9.0^{\mathrm{bc}}$ \\
Acc 33 & $249.1^{\mathrm{e}}$ & $19.3^{\mathrm{a}}$ & $13.9^{\mathrm{a}}$ & $8.6^{\mathrm{bcd}}$ \\
Acc 53 & $240.4^{\mathrm{ef}}$ & $16.6^{\mathrm{cd}}$ & $11.9^{\mathrm{b}}$ & $10.4^{\mathrm{a}}$ \\
Acc 57 & $311.5^{\mathrm{a}}$ & $14.7^{\mathrm{e}}$ & $10.4^{\mathrm{c}}$ & $7.9^{\mathrm{de}}$ \\
CL 1090 & $304.5^{\mathrm{ab}}$ & $13.3^{\mathrm{f}}$ & $9.6^{\mathrm{cd}}$ & $9.2^{\mathrm{bc}}$ \\
HB 20052 & $288.6^{\mathrm{c}}$ & $17.2^{\mathrm{c}}$ & $11.5^{\mathrm{b}}$ & $8.1^{\mathrm{de}}$ \\
HB 39 & $274.4^{\mathrm{d}}$ & $15.9^{\mathrm{d}}$ & $9.2^{\mathrm{de}}$ & $7.8^{\mathrm{e}}$ \\
Karimunda & $297.4^{\mathrm{bc}}$ & $13.8^{\mathrm{f}}$ & $8.4^{\mathrm{f}}$ & $9.2^{\mathrm{bc}}$ \\
Panniyur 1 & $285.6^{\mathrm{cd}}$ & $18.5^{\mathrm{b}}$ & $13.6^{\mathrm{a}}$ & $9.3^{\mathrm{b}}$ \\
PRS 88 & $196.1^{\mathrm{g}}$ & $15.0^{\mathrm{e}}$ & $9.5^{\mathrm{d}}$ & $8.6^{\mathrm{cd}}$ \\
CD @ 1\% & 18.487 & 1.146 & 1.097 & 0.96 \\
CD @ 5\% & 13.498 & 0.836 & 0.806 & 0.708 \\
\hline
\end{tabular}

Table 2. Pooled analysis (2014-17) on yield and yield attributing characters

\begin{tabular}{llccccc}
\hline Accession & $\begin{array}{c}\text { Fresh wt } \\
\left(\mathrm{kg} \mathrm{vine}^{-1}\right)\end{array}$ & $\begin{array}{c}\text { Dry weight } \\
(\mathrm{g} \text { plant }\end{array}$
\end{tabular}

\section{Character association}

The character association studies done for both penotypic and genotypic correlation. Significant positive phenotypic correlation existed between dry weight and fresh weight of berries (0.92). The association between all other characters was not significant.

The genotypic correlation studies revealed that, fresh weight is positively and significantly correlated only with dry weight of berries however it is significantly and negatively correlated with 100 berry weight, 100 berry 
Preethy et al.

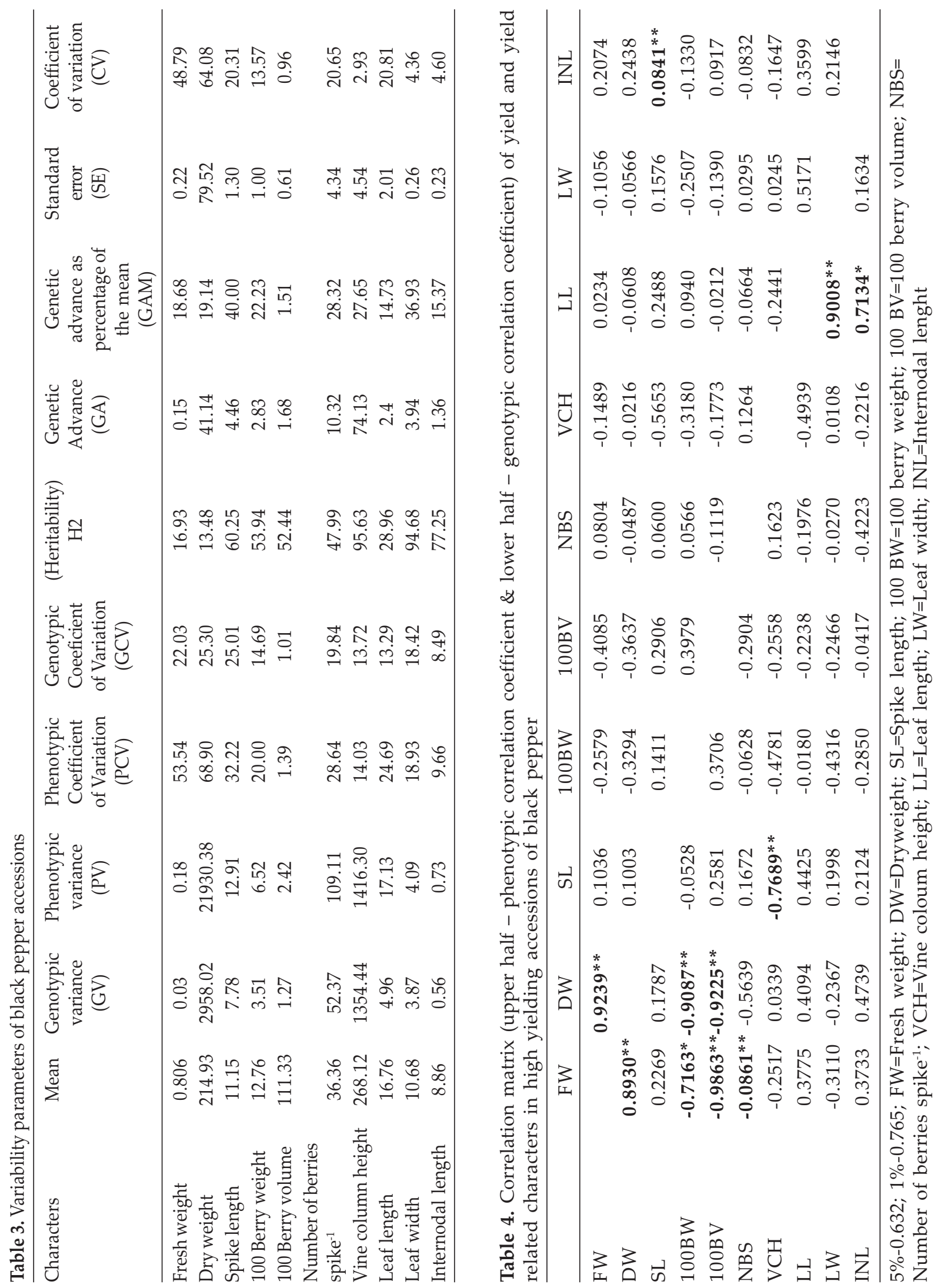


volume and number of berries spike ${ }^{-1}$. However, this is not corroborates with the findings of Sainamole et al. (2002) in which number of berries spike ${ }^{-1}$ is positively correlated to fresh yield. Therefore selection programme based on of dry weight of berries would be better than selection based on size of berries and number of berries spike ${ }^{-1}$ in black pepper. Dry weight of berries showed a negative significant genotypic correlation with 100 berry weight and 100 berry volume. Length of spike genetically correlated with vine column height which is significant and negative in direction. Same result had been reported by Sainamole et al. (2002). However, Sujatha \& Namboothiri (1995) reported positive and significant influence on yield with the spike length. Leaf length showed a significant positive genotypic correlation with leaf width and internodal length.

Productivity of black pepper depends on elevation, soil fertility, cultural practices, temperature, rainfall, age of the crop and climatic conditions during flowering, fruit set and development (Sivaraman et al. 1999). In the present study, Karimunda, Panniyur 1 and HB 20052 are found to be the suitable varieties for high ranges of Idukki district. The phenotypic expressions are more due to genotypic effect than environmental influence. These varieties can be utilized for further breeding programme in order to develop high yielding varieties suitable for high ranges of Idukki district. However based on the result of study conducted by Prasanna Kumari et al (2001) Karimunda did not perform well in Thodupuzha taluk. It may be due to the difference in environmental \& geographical parameters like altitude, rain, temperature etc. Selection of traits which are showing high heritability and genetic gain could be effective reflecting the presence of additive gene action.

\section{References}

Al-Jibouri Miller \& Robinson H F 1958 Genotypic and environmental variances and covariacnces in an upland cross of interspecific origin. Agron. J. 50: 633-636.

Sainamole Kurian P, Backiyarani S, Josephrajkumar A \& Murugan M 2002 Varietal evaluation of black pepper for yield, quality and anthracnose disease resistance in Idukki District, Kerala. J. Spices Arom. Crops 11: 122-124.

Sujatha R \& Namboothiri K M N 1995 Influence of plant characters on yield of black pepper (Piper nigrum L.). J. Trop. Agri. 33: 11-15.

Sivaraman K, Kandiannan K, Peter K V \& Thankamani C K 1999 Agronomy of black pepper (Piper nigrum L.) a review. J. Spices Arom. Crops 8: 1-18.

Thomas K V 2010 Awards for excellence in exports andproductivity ASEAN pact opening markets for India. www.indianspices.com/ php/pic_monthphp.

Ravindran P N \& Babu N K 1994 Genetic resources of black pepper. In: Chadha K L \& Rethinam P (Eds.), Advances in Horticulture Vol. 9. Plantation Crops and Spices Part I. Malhotra Publishing House, New Delhi.

Prasannakumari Amma S, Nybe E V, Sujatha V S \& Prabhakaran P V 2001 Survey, evaluation and identification of black pepper cultivars. J. Trop. Agri. 39: 9-12.

Deka K K, Bora P \& Talukdar J 2016 Performance of different varieties and hybrids of black pepper (Piper nigrum L.) as mixed crop in arecanut garden of Assam, India. Agri. Sci. Digest 36: 272-276.

Ibrahim K K, Pillay V S \& Sasikumaran S 1985 Variability, heritability and genetic advance for certain quantitative characters in black pepper. Agri. Res. J. 23: 45-48.

Ibrahim K K, Pillay V S \& Sasikumaran S 1987 Correlated response in yield and component characters in pepper (Piper nigrum L.). Agri. Res. J. 25: 263-264. 
Epidemiological parameters to delineate weather-disease interactions and host plant resistance against leaf blight in small cardamom (Elettaria cardamomum Maton)

\author{
C N Biju*, M F Peeran ${ }^{1}$, R Gowri' ${ }^{1}$ R Praveena, A Sharon \& S J Ankegowda ${ }^{1}$ \\ ICAR-Indian Institute of Spices Research, Kozhikode-673 012, Kerala. \\ ${ }^{*}$ E-mail: bijucn123@rediffmail.com
}

Received 07 February 2018; Revised 28 April 2018; Accepted 02 May 2018

\begin{abstract}
Small cardamom, the versatile spice of Zingiberaceae is cultivated in diverse agro-climatic regions of India especially in South India. Leaf blight incited by Colletotrichum gloeosporioides sensu lato is one among the major challenges encountered across different cardamom growing tracts. In the present investigation, epidemiology of cardamom leaf blight was studied and an attempt was made to decipher the resistant nature of Malabar, Mysore and Vazhukka genotypes based on epidemiological parameters. The average percent disease index recorded in Malabar, Mysore and Vazhukka varied from 23.41 to $27.72,18.79$ to 20.34 and 18.74 to 20.38 , respectively. The disease exhibited a positive correlation with respect to $\mathrm{T}_{\max }$ and $\mathrm{T}_{\min }$ in all the genotypes, however, significant correlation was observed only in Malabar and Mysore with respect to $\mathrm{T}_{\max }$. Whereas, rainfall and rainy days had negative correlation with leaf blight in all genotypes however found to be non-significant. The average infection rate was maximum (0.000429) in Malabar, whereas it was 0.000124 and 0.000186 in Mysore and Vazhukka, respectively. The area under disease progress curve registered the highest for Malabar (8814.15) and lowest in Vazhukka (6531.02) while, Mysore type recorded 6612.96 indicating that, Vazhukka and Mysore types might posses horizontal resistance and Malabar with vertical resistance. In the light of above results, plant protection measures could be scheduled based on the take-off level and genotypes with horizontal resistance could be promising candidates in resistance breeding programmes.
\end{abstract}

Keywords: apparent infection rate, area under disease progress curve, Colletotrichum, epidemiology, leaf blight, small cardamom

\section{Introduction}

Small cardamom (Elettaria cardamomum Maton) is a commercial Zingiberaceous spice originated and evolved in the biodiversity rich forest ecosystem of Western Ghats, India. Besides its centre of origin, cardamom is widely cultivated in Sri Lanka, Guatemala, Papua New Guinea and Tanzania (Ravindran 2002). The diverse species has morphologically evolved into Malabar, Mysore and Vazhukka genotypes distinguished primarily based on plant stature, leaf, panicle and capsule characters. A myriad of biotic and abiotic factors acts as major 
impediments to cardamom cultivation consequently leading to decline in gross cropped area and productivity. Among the foliar diseases, leaf blight incited by Colletotrichum spp. is noticed in all cardamom growing areas, inflicting damage invariably to all the genotypes. Divergent species belonging to the hemi-biotrophic ascomycetous pathogen, Colletotrichum incites leaf blight (Chethana et al. 2016). Though the disease is prevalent during the entire cropping season, it generally exacerbates and assumes epiphytotic proportions during post-monsoon period, probably favoured by an escalation in atmospheric temperature (Thomas \& Bhai 2002). The anamorphic phase (conidia) plays a pivotal role in the epidemiology of leaf blight facilitating dissemination and pathogenesis evidently favoured by conducive environmental factors. Delineating vulnerable crop stages with respect to weather factors and disease pattern helps to formulate and implement plant protection strategies economically and efficiently. Correlating the disease progression with weather variables adequately supports decision making process besides providing an indirect indication on pathogen dynamics. The apparent infection rate (r) in conjunction with area under disease progress curve (AUDPC) values could be effectively employed as epidemiological parameters to define vertical or horizontal nature of disease resistance (Van der Plank 1963; Nagarajan 1983). Adopting plant protection measures based on apparent infection rate helps targeting the initial inocula thereby checking disease spread. Definitive information on epidemiology of cardamom leaf blight and the role of $r$ and AUDPC parameters in disease progression as well as attempts towards deciphering the nature of resistance based on epidemiological parameters is scanty in cardamom-Colletotrichum host-pathosystem. Hence, the present investigation was formulated to delineate the relationship between disease progression vis-à-vis weather variables and an attempt was made to interpret the resistant nature of Malabar, Mysore and Vazhukka genotypes based on epidemiological parameters.

\section{Materials and methods}

Recording leaf blight incidence in field gene bank accessions

The study was carried out at ICAR-Indian Institute of Spices Research Regional Station, Appangala, Madikeri, Karnataka, India (12 ${ }^{\circ} 26^{\prime} \mathrm{N}$ Latitude, $75^{\circ} 45^{\prime} \mathrm{E}$ Longitude, 920 meters above MSL) during 2015-16. The experimental materials comprised of 119 field gene bank accessions and three released varieties (Appangala 1, IISR Avinash and IISR Vijetha) representing Malabar (41 accessions), Mysore (29 accessions) and Vazhukka (52 accessions) genotypes. The accessions used in the study were collected during exploration and collection programmes undertaken at diverse agro-climatic regions of major cardamom growing tracts and maintained in the in situ Field Gene Bank of the experimental location. The accessions/varieties (4 to 5 years old) were established under natural vegetation of shade trees during 2011 and each accession had five clumps each. The area under the experiment was maintained under uniform shade level and recommended package of practices were adopted to raise the crop with timely adoption of recommended plant protection chemicals to manage insect pests (thrips and panicle/shoot borer) and diseases (rhizome and root rot) other than leaf blight. Since, foliar diseases like leaf blotch, Phytophthora leaf blight and rust were either totally absent or less prevalent, foliar sprays with any of the recommended chemicals were not taken up. The incidence of leaf blight invariably relied on natural inoculum was visually recorded monthly employing 1-6 disease rating scale based on severity of foliar symptoms and percent disease index (PDI) was calculated. For scoring leaf blight incidence, peripheral portion of the clump comprising of senile tillers were avoided and the scoring was based on the manifestation of foliar symptoms on the inner tillers (minimum 8-12 tillers) of the clump. The PDI of all the accessions representing each genotype was calculated and averaged to depict the monthly average PDI for each genotype. Data on different weather variables such as 
maximum $\left(\mathrm{T}_{\max }\right)$ and minimum $\left(\mathrm{T}_{\min }\right)$ atmospheric temperature, rainfall and number of rainy days were also recorded daily and the monthly average values were computed. In order to study the relationship between various weather parameters and disease incidence by correlation studies, monthly averages of these weather factors was used.

Disease rating scale for leaf blight (1 to 6 scale) (Praveena et al. 2013; Senthil Kumar et al. 2018)

\begin{tabular}{cl}
\hline Category & Symptoms on leaves \\
\hline 1 & No symptoms \\
2 & Isolated spots \\
3 & $\begin{array}{l}\text { Sparse elongated spots on young } \\
\text { and mature leaves }\end{array}$
\end{tabular}

4 Coalescing elongated spots on young and mature leaves, $25 \%$ of leaf area is affected

5 Extensive elongated spots on all leaves, upto $50 \%$ of leaf area is affected, plant appears green from a distance

6 Total infection of all leaves, plant appears blighted from a distance

Percent Disease Index $(\mathrm{PDI})=\left\{\left[\mathrm{Y}_{1}(1-1)+\mathrm{Y}_{2}\right.\right.$ $\left.(2-1)+Y_{3}(3-1)+Y_{4}(4-1)+Y_{5}(5-1)+Y_{6}(6-1)\right] /$ $[\mathrm{N} \times 6]\} \times 100$

$Y_{1}$ to $Y_{6}=$ number of infected plants in each category

$\mathrm{N}=$ total plants in the plot

The accessions and the varieties were further categorized into highly resistant $(<10 \%)$, resistant $(11-20 \%)$, moderately resistant $(21-$ $30 \%)$, moderately susceptible (31-40\%), susceptible (41-50\%) and highly susceptible (> $51 \%$ ) based on percent disease index.

\section{Computing $r$ and AUDPC values}

The apparent infection rate (r) is a parameter used to analyze the momentum of epidemic development. The apparent infection rate was calculated for each genotype based on the formula suggested by Van der Plank (1963).

$r=\frac{2.3}{t 2-t 1} \log \left[\frac{x 2(1-x 1)}{x 1(1-x 2)}\right]$

where, $\mathrm{r}$ is the apparent infection rate, $\mathrm{x}_{1}$ is the disease index at initial time $\left(t_{1}\right), x_{2}$ is the disease index at subsequent observations $\left(t_{2}\right)$. The apparent infection rates were further employed to identify the highest and lowest infection periods with respect to each genotypes.

The AUDPC value was computed using the formula suggested by Wilcoxson et al. (1975).

$\sum_{i=1}^{n}\left(\frac{y i+y i+1}{2}\right)(t i+1-t)$

where, $y_{i}$ is the disease incidence at $i^{\text {th }}$ day of evaluation (initial observation), $\mathrm{y}_{\mathrm{i}}+1$ is the observation after the successive defined period, $t_{i+1}-t_{i}$ is the period between two observations and $\mathrm{n}$ is the number of successive evaluations.

\section{Results and discussion}

The percent disease index (PDI) observed in different cardamom genotypes along with weather variables recorded during October, 2015 to September, 2016 are presented in Table 1. Among the genotypes, Malabar comprised of 41 accessions and Mysore and Vazhukka comprised of 29 and 52 accessions, respectively. The period of observation spanned reproductive as well as vegetative phases of developmental stage and post-monsoon as well as monsoon periods as far as the weather pattern is concerned.

Leaf blight incidence in cardamom genotypes and variation in weather variables

In Malabar genotype, the maximum PDI $(27.72 \%)$ was recorded during May, 2016 whereas the minimum $(23.41 \%)$ was observed during October, 2015. In Mysore type, the PDI was in the range of $18.79 \%$ to $20.34 \%$ which was the minimum during July, 2016 and the disease registered as peak during April, 2016. 
In Vazhukka, the variation in PDI was $18.74 \%$ to $20.38 \%$ of which the minimum was noticed during December, 2015 while; the maximum was recorded during September, 2016. The maximum atmospheric temperature $\left(\mathrm{T}_{\max }\right)$ varied from $24.3^{\circ} \mathrm{C}$ to $33.7^{\circ} \mathrm{C}$ in which September, 2015 had the minimum and April, 2016 recorded the maximum. Whereas, the minimum atmospheric temperature $\left(\mathrm{T}_{\text {min }}\right)$ was in the range of $13.1^{\circ} \mathrm{C}$ to $18.7^{\circ} \mathrm{C}$ during January and May, 2016 respectively. The average monthly rainfall ranged between 0-653.4 $\mathrm{mm}$. During the period of observation, the rainfall was maximum during June, 2016 and minimum during February-March 2016. The rainy days were highest during August (29 days) and no precipitation was recorded during January to March 2016 (Table 1). Crop architecture and microclimate appears to be the deciding factors which favour incidence and proliferation of various diseases in the spice ecosystem. Nevertheless, the dynamic weather variables, often manifested in the form of erratic rainfall and temperature fluctuations over a period of time have unforeseen effects which may be even pose a threat to the production system in which these spice crops are grown either as principal or component crops. Murugan et al. (2017) observed that, climate change as evidenced through rise in ambient temperature and erratic rainfall immensely contributed to disease outbreaks in cardamom, demanding nonjudicious application of fungicides.

Patterns in disease progression and correlation with weather variables

The disease exhibited a positive correlation with respect to $\mathrm{T}_{\max }$ and $\mathrm{T}_{\min }$ in all the genotypes, however, significant correlation was observed only in Malabar and Mysore with respect to $\mathrm{T}_{\max }$. Whereas, rainfall and rainy days had negative correlation with the disease in all genotypes however found to be non-significant (Table 2). In Malabar, the disease progression followed a high-low-high pattern. The disease exhibited increasing trends during November, December, January, March, April, May, August

Table 1. Percent disease index in cardamom genotypes and weather variables during October 2015 to September 2016

\begin{tabular}{|c|c|c|c|c|c|c|c|}
\hline \multirow[t]{2}{*}{ Month } & \multicolumn{3}{|c|}{ PDI in different genotypes } & \multirow{2}{*}{$\begin{array}{l}\text { Maximum } \\
\text { atmospheric } \\
\text { temperature } \\
\left({ }^{\circ} \mathrm{C}\right)\end{array}$} & \multirow{2}{*}{$\begin{array}{l}\text { Minimum } \\
\text { atmospheric } \\
\text { temperature } \\
\left({ }^{\circ} \mathrm{C}\right)\end{array}$} & \multicolumn{2}{|c|}{ Weather variables } \\
\hline & Malabar & Mysore & Vazhukka & & & $\begin{array}{c}\text { Rainfall } \\
(\mathrm{mm})\end{array}$ & Rainy days \\
\hline October & 23.41 & 18.79 & 19.26 & 26.0 & 18.2 & 94.3 & 7 \\
\hline November & 25.28 & 20.34 & 19.32 & 26.1 & 17.7 & 75.2 & 4 \\
\hline December & 25.65 & 20.11 & 18.74 & 28.2 & 16.9 & 5.9 & 1 \\
\hline January & 26.13 & 19.36 & 19.03 & 28.2 & 13.1 & 1.0 & 0 \\
\hline February & 26.09 & 19.36 & 19.51 & 32.9 & 14.8 & 0 & 0 \\
\hline March & 26.99 & 20.17 & 19.93 & 33.6 & 18.2 & 0 & 0 \\
\hline April & 27.64 & 20.34 & 19.74 & 33.7 & 18.2 & 13.4 & 2 \\
\hline May & 27.72 & 20.11 & 19.93 & 32.9 & 18.7 & 161.2 & 11 \\
\hline June & 26.74 & 19.88 & 19.87 & 27.5 & 17.2 & 653.4 & 25 \\
\hline July & 25.40 & 18.79 & 18.94 & 25.2 & 16.4 & 537.2 & 27 \\
\hline August & 25.89 & 18.90 & 19.00 & 25.8 & 16.0 & 440.0 & 29 \\
\hline September & 26.42 & 19.54 & 20.38 & 24.3 & 16.0 & 251.4 & 19 \\
\hline
\end{tabular}


Table 2. Simple correlation between leaf blight incidence in cardamom genotypes with weather variables

\begin{tabular}{lccc}
\hline Weather variables & \multicolumn{3}{c}{ Correlation coefficient } \\
\cline { 2 - 4 } & Malabar & Mysore & Vazhukka \\
\hline Maximum atmospheric temperature $\left({ }^{\circ} \mathrm{C}\right)$ & ${ }^{*} 0.695$ & ${ }^{*} 0.668$ & $0.37063^{\mathrm{NS}}$ \\
Minimum atmospheric temperature $\left({ }^{\circ} \mathrm{C}\right)$ & $0.182^{\mathrm{NS}}$ & $0.559^{\mathrm{NS}}$ & $0.19754^{\mathrm{NS}}$ \\
Monthly rainfall $(\mathrm{mm})$ & $-0.055^{\mathrm{NS}}$ & $-0.481^{\mathrm{NS}}$ & $-0.25195^{\mathrm{NS}}$ \\
Number of rainy days & $-0.098^{\mathrm{NS}}$ & $-0.630^{\mathrm{NS}}$ & $-0.28827^{\mathrm{NS}}$ \\
\hline
\end{tabular}

$*=5 \%$ level of significance; NS = non significant

and September, whereas, decreasing trends were observed during October, February and JuneJuly. In Mysore genotype, leaf blight incidence registered peaks during November, March-April and August-September. While, the lowest incidence was noticed during October, December-February and May-July. In Vazhukka, decreasing trends in the PDI was observed during October-November, June-July and increasing pattern was noticed during November, January-March, May and AugustSeptember. In general, increasing as well as decreasing trends in disease progression were observed in all the genotypes during different months with a uniform increase during November, August and September whereas, a uniform decreasing trend was noticed during October, June and July. Though the impact of weather on diseases incited by Colletotrichum are well described by earlier workers, deciphering disease progression and host plant resistance through epidemiological parameters are not attempted in cardamom-Colletotrichum hostpathosystem. Alterations in temperature and moisture regimes influence population dynamics and pathogenicity of infectious agents and also might impact host physiology (Coakley et al. 1999; Chakraborty \& Datta 2003; Mina \& Sinha 2008). Physiological changes in host plants might result in increased resistance, leading to evolution of pathogens to prevail over host-plant resistance (Caffarra et al. 2012).

Foliar diseases incited by Colletotrichum species are generally favoured by temperature in the range of 25 to $35^{\circ} \mathrm{C}$, atmospheric humidity of
80-90\% and rainfall. Singh et al. (2009) reported that, anthracnose of guava incited by $C$. gloeosporioides attained a peak during September which had a negative correlation with maximum and minimum temperatures. The disease also exhibited a positive correlation with precipitation defined in terms of rainfall and number of rainy days. The minimum and maximum temperature regime for development of guava anthracnose was found to be 10 and $35^{\circ} \mathrm{C}$, respectively with an optimum of $30^{\circ} \mathrm{C}$ (Tandon \& Singh 1969). Bainik et al. (1998) reported the temperature range $28-34.2^{\circ} \mathrm{C}$ favours development of mango anthracnose. Though relative humidity had positive correlation with disease development, rainfall and number of rainy days had non-significant correlation (Ann et al. 1994). The sporulation in Colletotrichum is favoured by temperatures in the range of $20-25^{\circ} \mathrm{C}$, while temperatures above $30^{\circ} \mathrm{C}$ have an inhibitory effect (Kendrick \& Walker 1948; Slade et al. 1987; Mello et al. 2004). Cowger \& Mundt (2002) illustrated that, interaction of components conferring genotypic resistance with environmental factors is required to modify the effects of host diversity with respect to disease progression.

In cardamom system, it is speculated that Colletotrichum might have remained as cryptic dormant endophyte during anti-epidemic phase and subsequently activated during postmonsoon period particularly favoured by temperature. C. gloeosporioides colonized the internal foliar niche as endophyte in sweet orange which served as inoculum reservoirs 


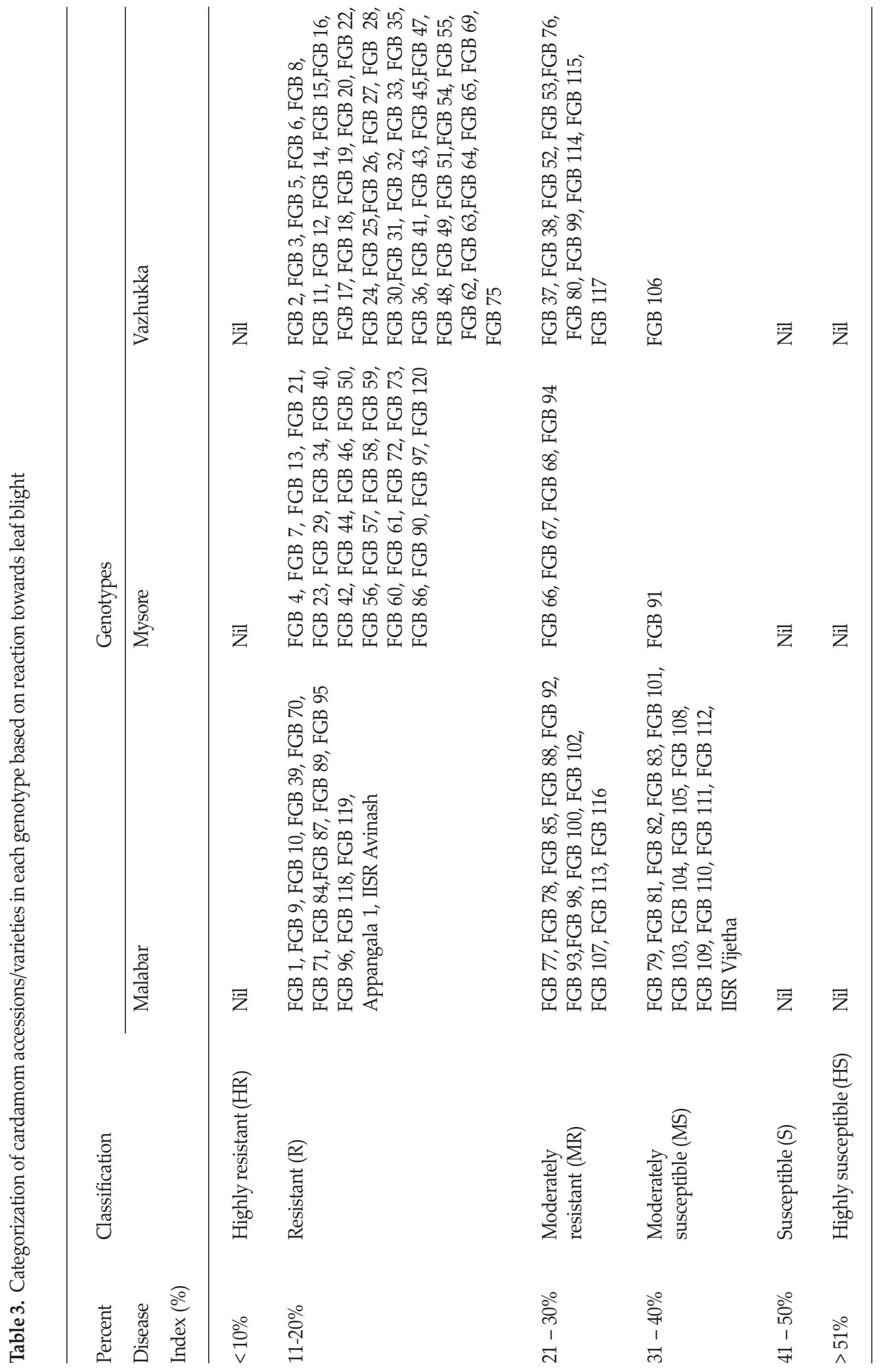


causing post blossom fruit drop during favourable weather (Andrade et al. 2017).

\section{Categorization of accessions based on resistance} towards leaf blight

The reaction exhibited by the genotypes and their categorization based on resistance/ susceptibility levels towards leaf blight are presented in Table 3. Based on the percent disease index recorded in different accessions, different categories were evolved in which the accessions were placed based on average monthly PDI. Among the accessions representing different genotypes, none exhibited highly resistant, susceptible or highly susceptible reactions towards leaf blight. In Malabar type, the average PDI ranged from 16.66 to $33.88 \%$. Of the 41 accessions evaluated, 24 exhibited resistant reaction and 12 and 14 accessions were categorized under moderately resistant and moderately susceptible categories. In Mysore genotype, of the 29 accessions evaluated, resistant reaction was exhibited by 24 accessions. Whereas, 4 accessions were grouped under moderately resistant category and one under moderately susceptible group wherein, the average PDI varied between 16.66 to $31.08 \%$. In Vazhukka with an average PDI range of 16.66 to $31.08 \%$ in which 41 accessions were grouped under resistant category and 10 and one accession exhibited moderately resistant and moderately susceptible reactions, respectively. Evolving genotypes possessing inherent resistance towards the invading pathogens is the most economical and ecofriendly approach to combat diseases. Identification of resistant sources and their subsequent incorporation in the breeding programmes are indispensible in the development of resistant varieties and considered as the most economical and sustainable strategy to combat diseases. The sources of resistant genes may be well distributed among elite cultivars, adopted nonelite germplasm, improved elite germplasm, land races, primitive varieties or wild related species as depicted in genetic diversity pyramid (Carson 1997). Earlier efforts to identify leaf blight resistance in cardamom germplasm resulted in the identification of glabrous selections of Malabar type viz., MA-15, MA-18 and MA-20 as moderately resistant and the compound panicle types, $\mathrm{CP}-2$ and $\mathrm{CP}-9$ as well as the land race Njallani Green Gold as resistant to the disease (Anon. 2004-05) besides, 22 leaf blight resistant accessions (Anon. 2006-07). Further, two accessions viz., IC-349588 and IC349613 which exhibited highly resistant reaction were found promising against leaf blight disease (Praveena et al. 2013). Concerted efforts in the direction to carry out extensive surveys in the hot spots of genetic diversity, collection and conservation of germplasm by establishing field gene banks, their subsequent characterization to identify desirable traits are essential in resistant breeding programmes for harnessing the existing genetic diversity within a diverse population.

\section{Trends in $r$ and AUDPC values}

The rate of disease spread as expressed in terms of r-value exhibited an erratic pattern irrespective of the genotypes. However, in general, the occurrence of anti-epidemics (where the $r$ value attained a negative phase) was found to be uniform in all the genotypes during JuneJuly. The average r-value was the highest (0.000429) for Malabar and least in Mysore (0.000124), whereas in Vazhukka it was 0.000186 (Table 4). The take-off level (an increase in r-value after attaining the anti-epidemic phase) was generally observed during JulyAugust which coincided with an average $\mathrm{T}_{\text {max }}$ of $24.5^{\circ} \mathrm{C}, \mathrm{T}_{\text {min }}$ of $16.2^{\circ} \mathrm{C}$ and rainfall and rainy days of $448.6 \mathrm{~mm}$ and 28 days. The AUDPC value was the maximum (8814.15) for Malabar and minimum (6531.02) in Vazhukka while it was 6612.96 in Mysore (Table 4). Critical analysis of the epiphytotics with respect to time, space and weather variables and its interpretation in terms of infection rate helps identifying the pattern of disease progression in a population and formulating diversified strategies to combat diseases with comparatively lesser efforts. Further, employing the epidemiological parameters including apparent infection rate and AUDPC values to identify resistant nature of the crop species have 
more implications besides merely deciphering the interaction of genotypes with weather variables on a time scale. The $r$ and AUDPC values derived from disease progression have been used to identify resistance nature of genotypes in several economically important crops like wheat, rice, potato, sunflower etc. against a variety of pathogens. Slow blighting cultivars are widely gaining acceptance in plant disease management as they reduce the momentum of disease spread, check the probable occurrence of epiphytotics without adversely affecting the potential yield. Genotypes possessing slow rusting/slow blighting quality governed by horizontal resistance mechanism exert less selection pressure on the invading pathogenic microbes resulting in preferential development of previously undetected virulent strains (Van der Plank 1963; Hooker 1967). Results from the present study indicated that, the apparent infection rate varied throughout the period of observation and remained inconsistent for a particular genotype and also did not exhibit a particular trend which might be attributed to genetic makeup of the genotype. Wilcoxson et al. (1975) and Nagesha \& Nargund (2005) observed the similar trends in wheat and sunflower, respectively. The area under disease progress curve is considered as a promising parameter to evaluate development of epidemics of foliar diseases considering genetic architecture of the genotypes. The experimental results suggested that, leaf blight severity primarily depends on prevailing weather conditions and resistance levels of the genotypes. The genotype which recorded higher AUDPC value exhibited severe leaf blight symptoms. The results indicated that, in this system climatic conditions could be a vital determinant favouring infection, as variation in PDI in all the genotypes was not drastic and toward resistance/susceptibility components. The AUDPC values differed considerably among the genotypes. The highest AUDPC value was observed in Malabar (8814.15) followed by Mysore (6612.96) and Vazhukka (6531.02). Based on the analyses of epidemiological parameters vis-à-vis host plant resistance, it is

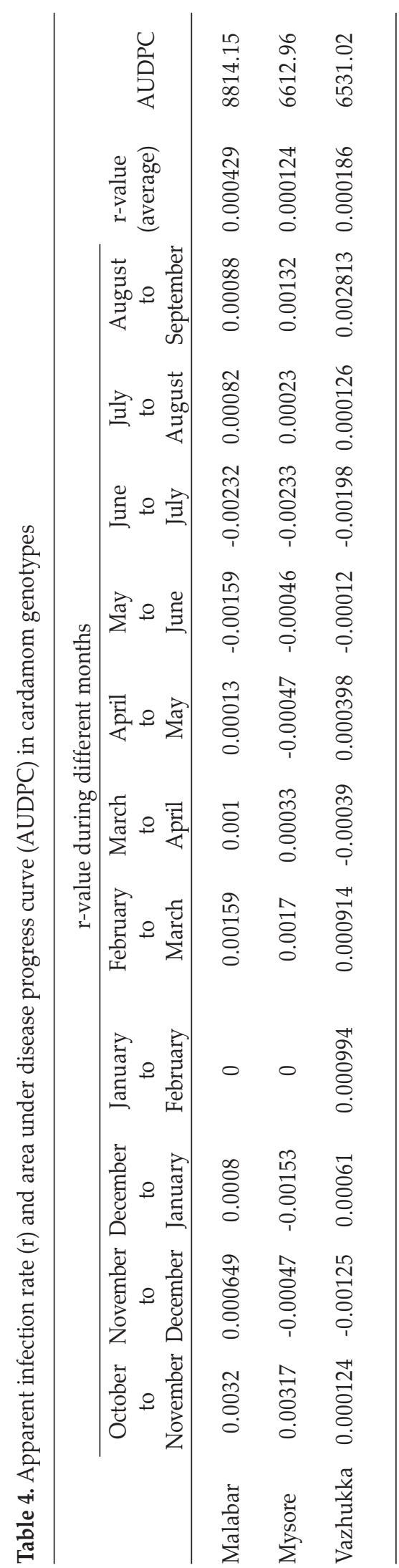


hypothesized that, resistance in Malabar types is governed by mono/oligo genes (vertical resistance) and Mysore as well as Vazhukka might possess horizontal resistance (governed by polygenes). Deciphering the nature of resistance based on $r$ and AUDPC values have been attempted by earlier workers in crops viz., wheat, potato and sunflower. Nagesha \& Nargund (2005) also reported lower AUDPC values in slow rusting varieties and higher values in susceptible varieties of sunflower. Hence, based on the AUDPC values, Malabar genotype could be considered as fast blighter and highly susceptible and Mysore as well as Vazhukka genotypes as slow blighters. Paraschivu et al. (2013) suggested that, there is a correlation between susceptibility of genotypes and AUDPC indicating that, highly susceptible wheat cultivars recorded high AUDPC values against Septoria tritici.

Non-judicious application of synthetic molecules might lead to several far-reaching consequences as it contributes immensely to the evolution of novel races of pathogens with fungicide resistance and pesticide residues in the produce. Besides deciphering the speed at which the disease spreads in a population, the $r$-value could be effectively employed to identify the stages at which the plant protection measures can be adopted, primarily targeting the initial inoculum $\left(X_{o}\right)$. In the present study it is observed that, in general, the r-value exhibited the trend of anti-epidemic phase during May-June and a take-off phase during July-August. Hence, undertaking plant protection measures with recommended fungicides before the commencement of monsoon (May-June) and during JulySeptember targeting the low inoculum levels would have significant adverse effect on the disease progression.

From the perspectives of epidemiology and host plant resistance it is concluded that, an increase in temperature during post-monsoon and precipitation have significant implications on disease progression. The trends observed with $r$ and AUDPC values indirectly indicated that, resistance in Malabar types may be governed by strong genes (vertical resistance) and weak genes (horizontal resistance) in Vazhukka and Mysore types. Further, based on the results, plant protection measures could be scheduled based on take-off phase of the disease to realize better management of the disease under field conditions.

\section{Acknowledgements}

The authors thank The Director, ICAR-Indian Institute of Spices Research, Kozhikode for providing facilities, Indian Council of Agricultural Research, New Delhi for financial support in the form of Outreach Programme on Diagnosis and Management of Leaf Spot Diseases in Field and Horticultural Crops and Mr. K. Jayarajan, ICAR-IISR, Kozhikode for statistical analysis.

\section{References}

Andrade W C E, Savi D C, Bini A P, Adamoski D, Goulin E H, Silva Jr G J, Massola Jr N S, Terasawa L G, Kava V \& Glienke C 2017 Colletotrichum gloeosporioides sensu stricto: an endophytic species or citrus pathogen in Brazil?. Australasian Plant Pathol. 46: 191203.

Ann P J, Huang H C \& Chen M F 1994 Effects of environmental factors on disease incidence of mango anthracnose. Plant Pathol. Bull. 3: $34-44$.

Anonymous 2004-05, Research Highlights, Indian Institute of Spices Research, Calicut, p.7.

Anonymous 2006-07, Research Highlights, Indian Institute of Spices Research, Calicut, p.11.

Bainik A K, Kaiser S A K M \& Dhua R S 1998 Influence of temperature and humidity on growth and development of Colletotrichum gloeosporioides and Diplodia natalensis causing post harvest fruit rot of mango. Adv. Plant Sci. 11: 128-132.

Caffarra A, Rinaldi M, Eccel E, Rossi V \& Pertot I 2012 Modelling the impact of climate change on the interaction between grapevine and its pests and pathogens: European grapevine moth and powdery mildew. Agri. Ecosys. Environ. 148: 89-101. 
Carson M L 1997 Plant breeding. In: Nancy A Rechcigl \& Jack E Rechcigl (Eds.), Environmentally safe approaches to crop disease control. CRC Lewis Publishers, Boca Raton, New York, pp.201-220.

Chakraborty S \& Datta S 2003 How will plant pathogens adapt to host plant resistance at elevated $\mathrm{CO}_{2}$ under a changing climate? New Phytologist 159: 733-742.

Chethana C S, Chowdappa P, Biju C N, Praveena R \& Sujatha A M 2016 Molecular and phenotypic characterization revealed six Colletotrichum species responsible for anthracnose disease of small cardamom in South India. Eur. J. Plant Pathol. 146: 465481.

Coakley S M, Scherm H \& Chakraborty S 1999 Climate change and plant disease. Annu. Rev. Phytopathol. 37: 399-426.

Cowger C \& Mundt C C 2002 Effects of wheat cultivar mixtures on epidemic progression of Septoria tritici blotch and pathogenicity of Mycosphaerella graminicola. Phytopathol. 92: 617-623.

Hooker A L 1967 The genetic and expression of resistance in plant to rusts of genus Puccinia. Annual Rev. Phytopathol. 57: 163-182.

Kendrick J B \& Walker J C 1948 Anthracnose of tomato. Phytopathol. 38: 247-260.

Mello A F S, Machado A C Z \& Bedeno I P 2004 Development of Colletotrichum gloeosporioides isolated from green pepper in different culture media, temperatures, and light regimes. Scientia Agricola 61: 542-544.

Mina U \& Sinha P 2008 Effects of climate change on plant pathogens. Environ. News 14: 610.

Murugan M, Ravi R, Anandhi A, Sajan Kurien \& Dhanya M K 2017 Pesticide use in Indian cardamom needs change in cultivation practices. Curr. Sci. 113: 1058-1063.

Nagarajan S 1983 Plant Disease Epidemiology. Oxford and IBH Publishing Company, New Delhi. p.267.

Nagesha G K \& Nargund V B 2005 Apparent rate of infection and area under disease progress curve: A measure of slow rusting in sunflower. Karnataka J. Agril. Sci. 18: 158161.

Paraschivu M, Cotuna O \& Paraschivu M 2013 The use of the area under the disease progress curve (AUDPC) to assess the epidemics of Septoria tritici in winter wheat. Res. J. Agril. Sci. 45: 193-201.

Praveena R, Biju C N, Senthil Kumar R, Darshana C N \& Jashmi K C 2013 Preliminary evaluation of cardamom accessions against leaf blight/Chenthal disease. Indian Phytopathol. 66: 112-113.

Ravindran P N 2002 Introduction. In: Ravindran P N \& Madhusoodanan K J (Eds.), Cardamom- The genus Elettaria., Taylor and Francis, New York, pp.1-10.

Senthil Kumar R, Sharon Aravind, Biju C N \& Ankegowda S J 2018 Characterization of genotypes of small cardamom (Elettaria cardamomum Maton) for yield parameters and disease resistance. J. Plantn. Crops (In Press).

Singh A, Verma K S \& Chander Mohan 2009 Effect of weather parameters on Colletotrichum gloeosporioides causing anthracnose of guava. Plant Disease Res. 24: 38-40.

Slade S J, Harris R F, Smith C S \& Andrews J H 1987 Microcycle conidiation and sporecarrying capacity of Colletotrichum gloeosporioides on solid media. Appl. Environ. Microbiol. 53: 2106-2110.

Tandon I N \& Singh B B 1969 Studies on anthracnose of guava and its control. Indian Phytopathol. 22: 322-326.

Thomas J \& Suseela Bhai R 2002 Diseases of cardamom. In: Ravindran $\mathrm{P} N$ \& Madhusoodanan K J (Eds.), Cardamom- The genus Elettaria. Taylor and Francis, New York, pp.160-179.

Van der Plank J E 1963 Plant disease epidemics and control. Academic press, New York, p.349.

Wilcoxson R D, Skovmand B \& Atif A H 1975 Evaluation of wheat cultivars for ability to retard development of stem rust. Annual Appl. Biol. 80: 275-281. 


\title{
Effect of drip irrigation on growth and yield of onion (Allium cepa L.)
}

\author{
P Bhasker*, R K Singh, R C Gupta, H P Sharma \& P K Gupta \\ National Horticultural Research \& Development Foundation, Regional Research Station, Chitegaon Phata, \\ Post-Darna Sangavi, Taluka-Niphad, Nashik-422 003, Maharashtra. \\ ${ }^{*}$ E-mail: bhasker_hau@yahoo.co.in
}

Received 20 May 2017; Revised 07 February 2018; Accepted 26 March 2018

\begin{abstract}
Drip irrigation is one of the essential, advanced and innovative irrigation methods over surface irrigation. In view of this, an experiment was conducted to study the efficiency of drip irrigation system over surface irrigation in onion during Rabi 2013-14 and 2014-15 and Kharif 2014 and 2015. The results revealed that drip irrigation system performed superior over surface irrigation system in terms of superior plant morphology, yield and quality of bulb. Drip irrigation recorded maximum plant height (66.37 $\mathrm{cm} \& 61.88)$, number of leaves (9.23 \& 8.00) and neck thickness $(1.62 \mathrm{~cm} \& 1.30 \mathrm{~cm})$ in both Rabi and Kharif seasons. The bulb equatorial and polar diameter, higher gross yield as well as marketable yield obtained in drip irrigation system. In drip, gross yield and marketable yield increased $18.16 \%$ and $24.49 \%$, respectively over surface irrigation method and better water use efficiency and also saved $29.36 \%$ and $27.12 \%$ water during Rabi and Kharif seasons, respectively.
\end{abstract}

Keywords: onion, drip irrigation, surface, yield, water use efficiency

\section{Introduction}

India is the second largest producer of onion next to China. Maharashtra state is the leading producing state in India. Onion is cultivated in three distinct seasons namely Kharif, late Kharif and Rabi. The soil moisture affect the quality of bulb and yield which is greatly influenced by the irrigation system. Onion is a shallow rooted crop needs light but frequent irrigation either by flood, sprinkler, or drip. The productivity of onion in India is 17.33 ton ha ${ }^{-1}$ which is low compared to world average. Managing the amount of applied irrigation water is critical to achieve optimum yield and quality. Most of the onion grown in India is under surface irrigation, which is relatively inexpensive, but inefficient in the amount of water use. Irrigation through drip is a new technique to increase agricultural production and to enhancing the efficiency of water use (Kusçu et al. 2009; Shock 2013; Enciso et al. 2015). Drip irrigation lends itself to automation, more so than either surface or sprinkler irrigation. Keeping this in mind, an experiment was planned on onion to study the feasibility of onion cultivation under drip irrigation. 


\section{Materials and methods}

A field trial was conducted during Rabi, 201314 and 2014-15 and Kharif 2014 and 2015 under "All India Network Research Project on Onion and Garlic" programme to study the feasibility of onion under drip irrigation system over surface irrigation on variety Agrifound Light Red for Rabi and Agrifound Dark Red for Kharif at the research farm of National Horticultural Research and Development Foundation, Nashik, Maharashtra. During experimental period meteorological data has given in Fig. 1. Soil of the experimental area was deep heavy clay with $\mathrm{pH}(7.60)$, organic carbon $(0.75 \mathrm{mg}$ $\left.\mathrm{g}^{-1}\right)$, available $\mathrm{N}\left(374.0 \mathrm{~kg} \mathrm{ha}^{-1}\right)$, available P (49. $\left.05 \mathrm{~kg} \mathrm{ha}^{-1}\right)$, available K (414.4 $\left.\mathrm{kg} \mathrm{ha}^{-1}\right)$, water holding capacity $(62.8 \%)$, field capacity $(38.9 \%)$ and permanent wilting point $(24.6 \%)$. The $55-$ 60 days aged seedlings were transplanted in the month of December for Rabi and for Kharif 4550 days old seedlings were transplanted in August.

The drip irrigation system was arranged in broad based furrow (BBF) system at spacing of $10 \times 15 \mathrm{~cm}$ in both drip and surface irrigation systems (farmers practice). BBF of $1.20 \mathrm{~m}$ top width with $0.45 \mathrm{~m}$ furrow maintaining $15 \mathrm{~cm}$ height, each BBF consists of two drip laterals (16 mm size) with inbuilt emitters. The distance between two inbuilt emitters was $50 \mathrm{~cm}$ and the discharge rate is $4 \mathrm{~L} / \mathrm{hr}$. The BBF system was prepared with a BBF former mounted behind a tractor. Single bed size was kept as $45.0 \mathrm{~m} \times 1.2 \mathrm{~m}$ in 6 replications and laid down in RBD design. The width of each bed and furrow was 1.2 and $0.45 \mathrm{~m}$, respectively; thus the width of one unit of BBF was $1.65 \mathrm{~m}$ simultaneously the crop raised under surface irrigation method was arranged in flat bed system in three rows, single bed size was $5.0 \mathrm{x}$ $2.0 \mathrm{~m}$, single row contains 7 beds.

Before transplanting of seedlings organic manures i.e. vermicompost @ 10 t ha $^{-1}$ along with Tricoderma viride $5 \mathrm{~kg} \mathrm{ha}^{-1}$ mixed with Azotobacter $10 \mathrm{~kg} \mathrm{ha}^{-1}$ applied in soil in both BBF and flat beds. The recommended dose of chemical fertilizers NPKS was 100:50:50:30 $\mathrm{kg} \mathrm{ha}^{-1}$. Fifty percent of $\mathrm{N}$ and $100 \% \mathrm{P}, \mathrm{K}$ and $\mathrm{S}$ applied at basal remaining $50 \% \mathrm{~N}$ applied in two splits at 30 \& 45 days after transplanting in flood irrigation flat bed system. Whereas, in drip

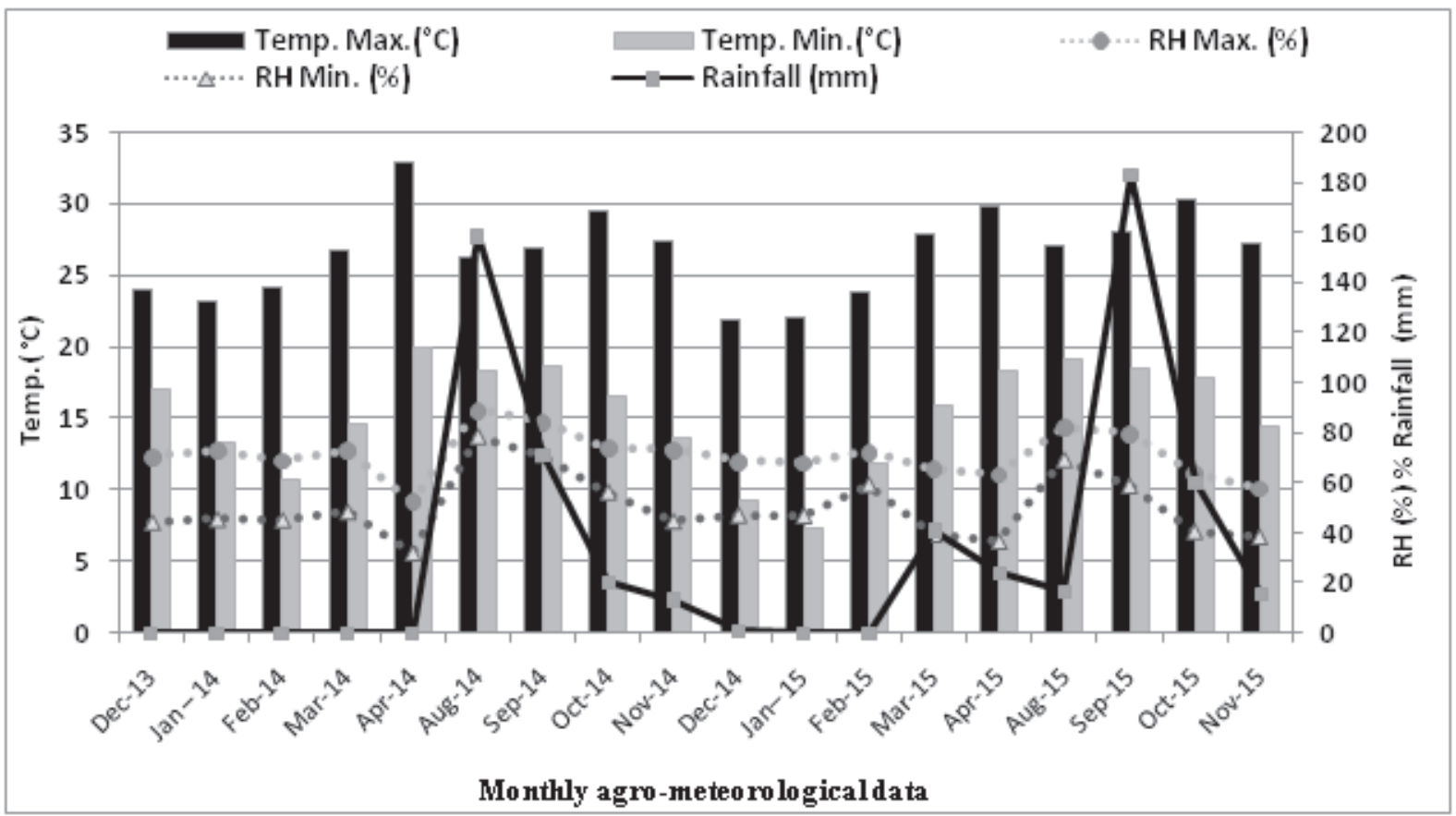

Fig. 1. Agro-meteorological data during crop growing period 
system fertigation was done with drip tank in 7 splits with 7 days intervals per day 2-3 hr. First irrigation was operated immediately after transplanting and light irrigation was done three days after transplanting for better and uniform initial establishment of crop. Recommended crop production and protection practices were followed as and when required to get good healthy crop. Following critical precautions were taken while conducting the experiment viz. irrigation interval followed uniformly; the operating pressure of drip system was $1.0-1.5 \mathrm{~kg} \mathrm{~cm}^{-2}$. In both the systems, irrigation was stopped at 15-20 days before crop harvesting. The bulbs were harvested at full maturity stage. After proper curing and neck cutting, the observations on yield and yield contributing characters and marketable bulb yield, percent of $A(>6.5 \mathrm{~cm}), B$ $(4.5-6.5 \mathrm{~cm})$ and $C(<4.5 \mathrm{~cm})$ grade bulbs on weight basis separately recorded and quantity of water applied was also measured.

\section{Results and discussion}

The results revealed that all growth and yield parameters of onion are significantly influenced by irrigation methods. The highest plant height i.e. $66.37 \mathrm{~cm}$ and $61.88 \mathrm{~cm}$ was recorded in drip irrigation raised bed system during Rabi and Kharif seasons, respectively, where as in surface irrigation flat bed system plant height was $65.00 \mathrm{~cm}$ and $51.52 \mathrm{~cm}$. Number of leaves and neck thickness were also higher in drip irrigation method in both Rabi (9.23/ plant and $1.62 \mathrm{~cm})$ and Kharif (8.0/ plant and $1.30 \mathrm{~cm}$ ) seasons (Table 1) that indicated that in drip irrigation raised bed system plant receive favourable conditions for enlargement of root system thereby plant growth and vigour is high. The results are in line with the results of Bhonde et al. (2003); Kumar et al. (2007) and Bangali et al. (2012) for plant growth. Drip provided require amount of water to the crop in small amounts delivered at frequent intervals as needed by the plant, and water losses to evaporation are less than with surface irrigation and also water is delivered at or below ground level, so that wetting of the foliage is not a problem. The drip irrigation affected the size of onion bulb, highest bulb equatorial $(6.15 \mathrm{~cm}$ $\& 5.15 \mathrm{~cm})$ as well as polar bulb diameter $(5.15$ $\mathrm{cm} \& 3.35 \mathrm{~cm}$ ) were recorded in drip irrigation and the lowest bulb diameter were recorded from the surface irrigation during Rabi and Kharif, respectively. Frequent amount of soil moisture application leads to large

Table 1. Effect of drip irrigation and surface irrigation systems on plant growth, yield and quality of onion cv. Agrifound Light Red for Rabi 2013-14 and 2014-15, and Agrifound Dark Red for Kharif season 2014 and 2015

\begin{tabular}{lcccccc}
\hline Growth and yield parameters & \multicolumn{3}{c}{ Rabi } & \multicolumn{4}{c}{ Kharif } \\
\cline { 2 - 6 } & Drip & Surface & CD (P<0.05) & Drip & Surface & CD (P<0.05) \\
\hline Plant height (cm) & 66.37 & 65.00 & 1.16 & 61.88 & 51.52 & 5.92 \\
Number of Leaf plant ${ }^{-1}$ & 9.23 & 8.18 & 0.93 & 8.00 & 6.77 & 0.96 \\
Neck thickness (cm) & 1.62 & 1.04 & 0.39 & 1.30 & 0.95 & 0.05 \\
Bolting (\%) & 0.56 & 2.22 & 0.22 & 0 & 0 & 0 \\
Doubles (\%) & 2.28 & 6.34 & 0.70 & 0 & 0.47 & 0.077 \\
Bulb equatorial diameter (cm) & 6.15 & 5.36 & 0.33 & 5.15 & 4.66 & 0.26 \\
Bulb polar diameter (cm) & 4.64 & 4.13 & 0.017 & 3.35 & 2.99 & N.S. \\
Gross yield (t ha $\left.{ }^{-1}\right)$ & 33.93 & 29.86 & 1.71 & 23.30 & 20.39 & 1.22 \\
Marketable yield (t ha $\left.{ }^{-1}\right)$ & 31.96 & 26.07 & 2.95 & 20.03 & 16.93 & 0.75 \\
A grade bulb (\%) & 63.07 & 53.68 & 1.72 & 28.96 & 15.98 & 3.39 \\
B grade bulb (\%) & 24.82 & 22.46 & 2.40 & 36.28 & 34.16 & 1.21 \\
C grade bulb $(\%)$ & 12.11 & 23.86 & 6.32 & 34.76 & 49.86 & 2.29 \\
\hline
\end{tabular}


photosynthesis area resulted highest plant height and large number of leaves leads to large bulb diameter and yield. The highest total bulb yield (33.93 \& $23.30 \mathrm{t} \mathrm{ha}^{-1}$ ) and marketable yield (31.96 \& $20.03 \mathrm{t} \mathrm{ha}^{-1}$ ) were recorded in drip irrigation system in both Rabi and Kharif seasons, whereas as in flood irrigation lowest gross yield (29.86 \& $\left.23.30 \mathrm{t} \mathrm{ha}^{-1}\right)$ as well as marketable yield $\left(26.07 \& 16.93 \mathrm{t} \mathrm{ha}^{-1}\right)$ were recorded. The gross yield and marketable yield increased $18.16 \%$ and $24.49 \%$, respectively over surface irrigation. Drip irrigation with fertigation of NPK nutrients with regular intervals enables better plant growth caused higher photosynthesis levels and higher carbohydrates accumulation in sink region. It is evidenced from the results presented in this study is inclusive and similar with previous researchers (Balasubramanyan et al. 2001; Quadir et al. 2005; Tripathi et al. 2010; Bangali et al. 2012). The results further revealed that drip irrigation provided lower bolting (0.56\%) and doubles (2.28\%) as compared with surface system and it was observed that during Kharif season bolting did not record in any treatments because the average minimum temperature is above $17^{\circ} \mathrm{C}$ is not favourable to initiate bolting, however doubles were recorded (Table 2).

Nashik comes under shadow of a southwest monsoon; hence the erratic summer monsoon experienced by this region sets in last part of June and extends till the $2^{\text {nd }}$ week of October. The mean average rainfall varied from $548.0 \mathrm{~mm}$ to $862.0 \mathrm{~mm}$ during 2013 to 2015 . Rainfall was coincided with bulb initiation and bulb development phases, due to heavy rain fall during Kharif season poor bulb development was observed. This is the reason and other climatic reasons during Kharif season $36.32 \%$ yield decreased as compared with Rabi, however by adopting drip irrigation system in Kharif season considerable yield was increased over surface irrigation method because drip irrigation raised bed system up to some extent remove excess water and avoid water logging due to slow and steady runoff water as compared with surface flat bed system where crop was affected. Over all during Kharif season in drip irrigation, the gross yield and
Table 2. Benefits of drip irrigation system over surface irrigation system during Rabi and Kharif seasons at Nasik region of Maharashtra

\begin{tabular}{lcc}
\hline Parameters & Rabi & Kharif \\
\hline Gross yield (\%) & 13.64 & 14.27 \\
Marketable yield (\%) & 22.61 & 18.30 \\
A grade bulb (\%) & 17.49 & 81.24 \\
B grade bulb (\%) & 10.51 & 5.94 \\
C grade bulb (- \%)* & 49.84 & 30.29 \\
Water saving (\%) & 29.36 & 27.12 \\
Water use efficiency (\%) & 60.87 & 56.79 \\
\hline
\end{tabular}

*Per cent decreased over surface irrigation

marketable yield increased $14.27 \%$ and $18.30 \%$, respectively. It is evidenced from the results, properly designed and managed drip irrigation raised bed has many advantages over surface irrigation including: elimination of surface runoff, high uniformity of water distribution, high water usage efficiency, flexibility in fertilization, prevention of weed growth and plant disease during rainy season. The results further revealed that highest ' $A$ ' grade $(>6.0 \mathrm{~cm})$ bulb $(63.07 \%)$, 'B' grade $(4.0-6.0 \mathrm{~cm})$ bulb $(24.82 \%)$ and lower ' $\mathrm{C}$ ' grade $(<4.0 \mathrm{~cm})$ bulb $(12.10 \%)$ were recorded in drip irrigation system during Rabi season and in Kharif also higher 'A' grade bulb (28.97\%), 'B' grade bulb (36.28\%) and lower ' $C$ ' grade bulb $(34.76 \%)$ recorded in drip irrigation system (Table 3). Drip irrigation ensures optimum growth, better bulbing and early maturity of crops by assuring optimum soil moisture, water, air and nutrients throughout the crop growing period resulting uniform bulb obtained is directly correlated to the highest bulb size and productivity, whereas in surface irrigation yield decreased due to deep percolation and water is lost beyond the active absorption zone of the root system as an onion is shallow rooted crop. These results are in line with the results of Hanson \& May (2005) and Tripathi et al. (2010).

The benefits of drip irrigation system over surface irrigation are illustrated in Table 4, that applied water in drip system is very lower in 
two seasons as compare with surface irrigation system. The 60.29 ha $\mathrm{cm}^{-1}$ and $55.65 \mathrm{ha} \mathrm{cm}^{-1}$ quantity of water was applied in drip system during Rabi and Kharif, respectively where as in flood system $85.35 \mathrm{ha} \mathrm{cm}^{-1}$ and $76.35 \mathrm{ha} \mathrm{cm}^{-1}$, respectively. Thus, the drip system could save $29.36 \%$ and $27.12 \%$ water during Rabi and Kharif, respectively. The primary reasons attributed for the water savings include irrigation of a smaller portion of the soil volume, decreased surface evaporation, reduced irrigation runoff from the drip field and controlled deep percolation losses below the crop root zone, which enables higher water use efficiency in drip irrigation raised bed system, which was $562.79 \mathrm{~kg} \mathrm{ha}^{-1} \mathrm{~mm}$ for Rabi and $418.69 \mathrm{~kg} \mathrm{ha}^{-1} \mathrm{~mm}$ for Kharif (Fig. 2). The results were similar in line with results of Halim \& Ener (2001) and Nagaz et al. (2012). Based on water consumption of crop calculated that during Rabi season 1000 lit of water is utilized for production of $5.62 \mathrm{~kg}$ and $3.49 \mathrm{~kg}$ of onion in drip and surface irrigation, respectively. Whereas in Kharif season 1000 litre of water by drip produces $4.18 \mathrm{~kg}$, while in surface it is 2.67 $\mathrm{kg}$, therefore drip irrigation system well suited for shallow rooted onion. The Cost: Benefits ratio also high in drip (1:2.69) while in surface irrigation it is 1: 1.68. The Cost: Benefits ratio in drip suggests that despite higher initial cost of the drip system, the drip irrigation is more profitable than the surface irrigation.

Based on the obtained results of Rabi and Kharif seasons of the effect of drip irrigation on yield, yield components and morphological characteristics of onion, as well as water use efficiency and water saving it concluded that drip irrigation is highly significant effect on all studied parameters. To achieve a high production potential of onion, adopting drip irrigation should be maintained during the both Rabi and Kharif seasons.

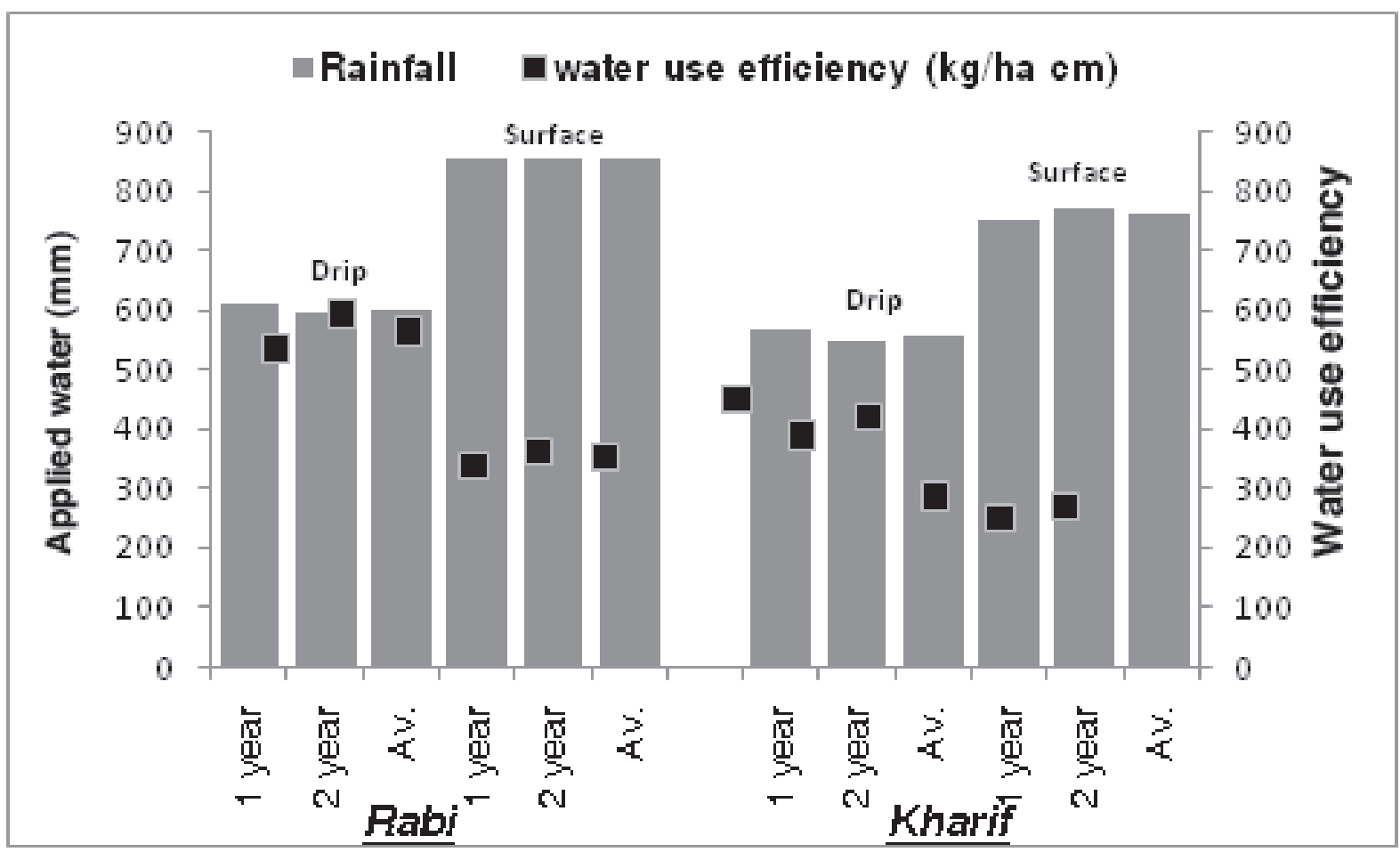

Fig. 2. Effect of drip irrigation and surface irrigation systems on water consumption and water use efficiency of onion cv. Agrifound Light Red for Rabi 2013-14 and 2014-15, and Agrifound Dark Red for Kharif season 2014 and 2015 


\section{References}

Bagali A N, Patil H B, Guled M B \& Patil R V 2012 Effect of scheduling of drip irrigation on growth, yield and water use efficiency of onion (Allium cepa L.). Karnataka J. Agri. Sci. 25: 116-119.

Balasubrahmanyam V R, Dhakae A V \& Moitra P 2001 Microirrigation and Fertigation in onion. In: Proc. Int. Conf. Micro and Sprinkler irrigation Systems, Jalgaon, Maharashtra.

Bhonde S R, Singh N B \& Singh D K 2003 Studies on the effect of drip irrigation in onion bulb crop. NHRDF Newsletter 23: 1-3.

Enciso J, Jifon J, Anciso J \& Ribera L 2015 Productivity of Onions Using Subsurface Drip Irrigation versus Furrow Irrigation Systems with an Internet Based Irrigation Scheduling Program. Int. J. Agron. Article ID 178180, Available online at http:// dx.doi.org/10.1155/2015/178180.

Halim O A \& Ener M 2001. A study on irrigation scheduling of onion (Allium cepa L.). Turkey J. Biol. Sci. 1: 735-736.

Hanson B R, May D M 2004 Response of processing and fresh market onions to drip irrigation. Acta Hort. 664: 399-405.
Kumar S, Imtiyaz M, Kumar A \& Singh R 2007 Response of onion to different levels of irrigation water. Agric. Water Mgnt. 89: 161166.

Kusçu H, Çetin B \& Turhan A 2009 Yield and economic return of drip irrigated vegetable production in Turkey. New Zealand J. Crop Hort. Sci. 37: 51-59.

Nagaz K M, Masmoudi M \& BenMechlia N 2012 Effects of deficit drip-irrigation scheduling regimes with saline water on pepper yield, water productivity and soil salinity under arid conditions of Tunisia. J. Agri. Environ. Int. Dev. 106: 85-103.

Quadir M, Boulton A, Ekman J, Hickey M \& Hoogers R 2005 Influence of drip irrigation on onion yield and quality. IREC Farmers Newslett. 170: 29-31.

Shock C C 2013 Drip Irrigation: An Introduction. Oregon State University Extension publication. EM 8782. Available online at http:// ir.library. oregonstate.edu/ xmlui/ bitstream/handle/1957/ 20206/em8782-e.

Tripathi P C, Sankar V \& Lawande K E 2010 Influence of micro irrigation methods on growth, yield and storage of Rabi onion. Indian J. Hort. 67: 61-65. 
Influence of organic and inorganic fertilizers on yield and quality of sweet basil (Ocimum basilicum L.)

\author{
B Al-mansour, D Kalaivanan¹, M A Suryanarayana², K Umesha \& A K Nair ${ }^{3}$ \\ Department of Plantation, Spices, Medicinal and Aromatic Crops, \\ College of Horticulture, UHS Campus, Bengaluru, Karnataka. \\ *E-mail: baraaalmansour@yahoo.com
}

Received 25 November 2017; Revised 30 January 2018; Accepted 02 January 2018

\begin{abstract}
Field experiments were carried out during Kharif season of 2015 and 2016 to study the influence of FYM, inorganic fertilizers and bio-fertilizers on fresh herbage yield, quantity and quality of essential oil of sweet basil (Ocimum basilicum). Nine treatments with three replications were adopted in a randomized block design to find out the effect of different levels of $\mathrm{N}$ applied through FYM (100, 75 and $50 \%$ of the recommended $\mathrm{N}$ along with and without bio-fertilizers), recommended dose of NPK (160:80:80 $\left.\mathrm{kg} \mathrm{ha}^{-1}\right)$, recommended FYM (10 t ha-1) + NPK (160:80:80 $\mathrm{kg} \mathrm{ha}^{-1}$ ) and control (recommended FYM $\left(10 \mathrm{t} \mathrm{ha}^{-1}\right)$ on fresh herbage and oil yield, oil content and oil quality of sweet basil (Ocimum basilicum L.). Pooled results revealed that application of recommended FYM (10 $\left.\mathrm{t} \mathrm{ha}^{-1}\right)$ along with recommended NPK (160:80:80 $\left.\mathrm{kg} \mathrm{ha}^{-1}\right)$ recorded the highest fresh herbage yield (39.95 and $\left.19.37 \mathrm{t} \mathrm{ha}^{-1}\right)$, essential oil content $(0.48$ and $0.45 \%)$ and essential oil yield (199.7 and $107.58 \mathrm{~kg} \mathrm{ha}^{-1}$ ) in the main crop and ratoon, respectively. With respect to oil quality, bio-fertilizer has a good impact on oil quality, that highest percentage of Methyl chavicol was recorded with application of recommended FYM (10 t ha $\left.{ }^{-1}\right)+$ recommended $\mathrm{N}$ through FYM along with bio fertilizers in the main crop of 2016 (63.78\%) and in the ratoon (59.39 and 59.67\%) of 2015 and 2016, respectively.
\end{abstract}

Keywords: bio-fertilizer, FYM, herbage, inorganic fertilizer, oil quality and basil

\section{Introduction}

Sweet basil (Ocimum basilicum L.) is one of the most important essential oil producing aromatic plant, is grown worldwide for its medicinal, flavoring and industrial properties. The economic parts of the plant include leaves, flowers and seeds. The medicinal impact of basil results from the presence of phenolic compounds, flavonoids and other substances in its essential oil which have antibacterial (Nour et al. 2009), anti-mycotic and antioxidant activities (Sekar et al. 2009).

Basil is considered as a species with substantial nutritional and fertilization needs. It responds extremely well to nitrogen fertilization. The yield of basil increases when the dose of

${ }^{1}$ Division of Soil Science \& Agricultural Chemistry, ${ }^{2}$ Division of Floriculture and Medicinal Crops, ${ }^{3}$ Division of Vegetable Crops, ICAR-Indian Institute of Horticultural Research, Bengaluru-560 089, Karnataka. 
nitrogen increases (Daneshian et al. 2009; Biesiada \& Ku 2010), but intensive farming that need high input of mineral fertilizers is considered as serious damage that may affect soil health, sustained production and balanced environment (Anwar et al. 2007). Taking into consideration of the deleterious effect of continuous applying of mineral fertilizer on the soil structure, organic farming could consider as a suitable replacement of inorganic fertilizer for improving microbial population, and soil organic matter (Shahram \& Ordookhani 2011). Reza et al. (2015) claimed that substituting chemical fertilizers by organic manures and biofertilizers, could consider as a good farming system improve the ecosystem and soil health as a step for achieving sustainability in agriculture.

Besides this, for medicinal and aromatic plants (MAPs), the real value is given to the quality rather than quantity, so that organic farming is considered as a suitable approach that enhances the performance of these crops. However, complete replacement of inorganic fertilizers by the organic manures is not advisable owing to their very low nutrient concentration and in turn requirement in huge quantities which may not be possible due to scarcity of such materials. In this endeavor, a blend of organic and inorganic fertilizers is important for improving the yield, maintaining soil health and keeping favorable ecological conditions on long-term basis. Amran (2013) and El-khyat (2013) revealed that application of organic manure along with half dose of chemical fertilizer had a positive impact on the oil yield of Pelargonium graveolens and Rosmarinus officinalis. The quality of the essential oil in basil is determined by the percentage of its volatile molecules which is affected by soil and climate conditions. Combined application of organic manure and inorganic fertilizer is considering the best tool that can be used to improve the yield and quality of these plants. Despite the importance of the basil crop, information on different aspects of growth, development, influence of organic manure and inorganic fertilizers on herbage and oil yield is very meager. In this context, this study was aimed to find out the "Influence of FYM, inorganic fertilizer and bio-fertilizers on herbage, oil yield, essential oil content and oil quality of sweet basil.

\section{Material and methods}

Field experiments were conducted in the experimental field at ICAR-Indian Institute of Horticultural Research (ICAR-IIHR), Bangalore during the kharif season of 2015 and 2016. The experimental station is located at an altitude of $890 \mathrm{~m}$ above mean sea level and 13058" N latitude and $77^{\circ} 29^{\prime \prime} \mathrm{E}$ longitudes. The nine treatments of experiment contain $\mathrm{T}_{1}\left(\mathrm{FYM}\left(10 \mathrm{t} \mathrm{ha}^{-1}\right)+\right.$ $100 \%$ recommended $\mathrm{N}$ through FYM), $\mathrm{T}_{2}$ (FYM $\left(10\right.$ t ha $\left.^{-1}\right)+100 \%$ recommended $N$ through FYM + bio-fertilizer), $\mathrm{T}_{3}$ (FYM (10 $\mathrm{t} \mathrm{ha}^{-1}$ ) + 75\% recommended $\mathrm{N}$ through FYM), $\mathrm{T}_{4}$ (FYM (10 t ha $\left.^{-1}\right)+75 \%$ recommended $\mathrm{N}$ through FYM + biofertilizer), $\mathrm{T}_{5}$ (FYM (10 $\left.\mathrm{t} \mathrm{ha}^{-1}\right)+50 \%$ recommended $\mathrm{N}$ through FYM), $\mathrm{T}_{6}$ (FYM (10 $\mathrm{t}$ ha $\left.^{-1}\right)+50 \%$ recommended $\mathrm{N}$ through FYM + biofertilizer), $\mathrm{T}_{7}$ (recommended FYM (10 $\mathrm{t} \mathrm{ha}^{-1}$ only), $\mathrm{T}_{8}$ (recommended NPK (160:80:80 kg ha-1) only, and $\mathrm{T}_{9}$ (recommended FYM $10 \mathrm{t} \mathrm{ha}^{-1}$ ) + recommended NPK (160:80:80 kg ha-1). Treatments were replicated thrice in a randomized complete blocks design. Physical and chemical properties of the initial experimental soil are presented in (Table 1). The nutrients were supplied in the form of straight fertilizers like urea (160 kg N ha-1), single super phosphate $\left(80 \mathrm{~kg} \mathrm{P}_{2} \mathrm{O}_{5} \mathrm{ha}^{-1}\right)$ and muriate of potash $\left(80 \mathrm{~kg} \mathrm{~K}_{2} \mathrm{O} \mathrm{ha}^{-1}\right)$. Fifty per cent of nitrogen and full dose of phosphate and potash were applied as basal dose and the remaining fifty per cent of $\mathrm{N}$ was applied after 45 days of transplanting in $\mathrm{T}_{8}$ and $\mathrm{T}_{9}$ treatments. For biofertilizers, Arka Microbial Consortium (AMC) developed by ICAR-IIHR was used in the experiment and it contains $\mathrm{N}$ fixing, $\mathrm{P}$ and $\mathrm{Zn}$ solubilizing and plant growth promoting microbes in a single carrier. After 15 days of transplanting, recommended dose of AMC @5 $\mathrm{kg} \mathrm{ha}^{-1}$ was applied at $2 \mathrm{~cm}$ deep to individual plants and immediately covered with soil. Similar method of application was also followed for ratoon crop after harvest of main crop in $\mathrm{T}_{2}, \mathrm{~T}_{4}$ and $\mathrm{T}_{6}$ treatments. Quantities of added fertilizers are given in (Table 2). 
Table 1. Physical and chemical proprieties of initial experimental soil

\begin{tabular}{lr}
\hline Physical properties & \\
\hline Bulk density $\left(\mathrm{Mg} \mathrm{m}^{-3}\right)$ & 1.32 \\
Particle Density $\left(\mathrm{Mg} \mathrm{m}^{-3}\right)$ & 2.65 \\
Pore space $(\%)$ & 42 \\
\hline Chemical properties & 7.75 \\
\hline $\mathrm{pH}(1: 2.5)$ & 0.36 \\
Electrical conductivity $\left(\mathrm{dSm}^{-1}\right)$ & 5.0 \\
Organic carbon $\left(\mathrm{g} \mathrm{kg}^{-1}\right)$ & 185 \\
Available N $\left(\mathrm{kg} \mathrm{ha}^{-1}\right)$ & 28 \\
Available P $\left(\mathrm{kg} \mathrm{ha}^{-1}\right)$ & 200 \\
Available K $\left(\mathrm{kg} \mathrm{ha}^{-1}\right)$ & 5.25 \\
Exchangeable Ca $\left.\left(\mathrm{cmol}^{(1} \mathrm{p}^{+}\right) \mathrm{kg}^{-1}\right)$ & 0.84 \\
Exchangeable Mg $\left(\mathrm{cmol}^{+}\left(\mathrm{p}^{+}\right) \mathrm{kg}^{-1}\right)$ & 7.5 \\
DTPA Fe $\left(\mathrm{mg} \mathrm{kg}^{-1}\right)$ & 5.8 \\
DTPA Mn $\left(\mathrm{mg} \mathrm{kg}^{-1}\right)$ & 1.33 \\
DTPA Cu $\left(\mathrm{mg} \mathrm{kg}^{-1}\right)$ & 1.22 \\
DTPA Zn $\left(\mathrm{mg} \mathrm{kg}^{-1}\right)$ &
\end{tabular}

Each experimental plot size was $4.8 \mathrm{~m}$ long and $4 \mathrm{~m}$ wide with spacing of $40 \mathrm{~cm}$ between the plants and $60 \mathrm{~cm}$ between the rows. There was a space of 0.5 meter between the plots and 0.5 meter between replications. Basil variety CimSaumya (CIMAP) was sown in two nursery beds of $6.0 \mathrm{~m}$ in length with $1 \mathrm{~m}$ in width and $10 \mathrm{~cm}$ height. Forty days old (40) healthy and uniformly rooted seedlings of sweet basil were transplanted to the field. Weeding was done manually and drip irrigation was given daily for half an hour in the early stages and subsequently irrigation was given depending on the soil moisture condition. Fresh weight from each plot was converted to per hectare and it was expressed in tones ( $t)$. In order to determine the essential oil content (\%), a sample of $100 \mathrm{~g}$ of basil fresh herb from the each plot were collected and mixed with $500 \mathrm{ml}$ distilled water and then were subjected to hydrodistillation for $3 \mathrm{~h}$ using a Clevenger-type apparatus (Darzi et al. 2012). The quality of basil oil samples was analyzed by gas

Table 2. Treatment wise applied quantities of FYM, inorganic fertilizer and bio-fertilizers

\begin{tabular}{|c|c|c|c|c|c|c|}
\hline \multirow[t]{2}{*}{ Treatments } & \multicolumn{3}{|c|}{ Quantity of inputs } & \multicolumn{3}{|c|}{ Total nutrient supplied } \\
\hline & $\begin{array}{l}\text { FYM } \\
\left(\mathrm{t} \mathrm{ha}^{-1}\right)\end{array}$ & $\begin{array}{c}\text { NPK } \\
\left(\mathrm{kg} \mathrm{ha}^{-1}\right)\end{array}$ & $\begin{array}{c}\mathrm{BF}^{*} \\
\left(\mathrm{~kg} \mathrm{ha}^{-1}\right)\end{array}$ & $\begin{array}{c}\mathrm{N} \\
\left(\mathrm{kg} \mathrm{ha}^{-1}\right)\end{array}$ & $\begin{array}{c}\mathrm{P} \\
\left(\mathrm{kg} \mathrm{ha}^{-1}\right)\end{array}$ & $\begin{array}{c}\mathrm{K} \\
\left(\mathrm{kg} \mathrm{ha}^{-1}\right)\end{array}$ \\
\hline $\begin{array}{l}\mathrm{T}_{1}: \mathrm{FYM}\left(10 \mathrm{t} \mathrm{ha}^{-1}\right)+100 \% \\
\text { Rec. N through FYM }\end{array}$ & 35 & 0 & - & 224 & 39.2 & 31.5 \\
\hline $\begin{array}{l}\mathrm{T}_{2}: \mathrm{FYM}\left(10 \mathrm{t} \mathrm{ha}^{-1}\right)+100 \% \text { Rec. } \\
\mathrm{N} \text { through FYM }+\mathrm{BF}\end{array}$ & 35 & 0 & 5 & 224 & 39.2 & 31.5 \\
\hline $\begin{array}{l}\mathrm{T}_{3}: \mathrm{FYM}\left(10 \mathrm{t} \mathrm{ha}^{-1}\right)+75 \% \text { Rec. } \\
\mathrm{N} \text { through FYM }\end{array}$ & 28.75 & 0 & - & 184 & 32.2 & 25.9 \\
\hline $\begin{array}{l}\mathrm{T}_{4}: \mathrm{FYM}\left(10 \mathrm{t} \mathrm{ha}^{-1}\right)+75 \% \text { Rec. } \\
\mathrm{N} \text { through FYM + BF }\end{array}$ & 28.75 & 0 & 5 & 184 & 32.2 & 25.9 \\
\hline $\begin{array}{l}\mathrm{T}_{5}: \mathrm{FYM}\left(10 \mathrm{t} \mathrm{ha}^{-1}\right)+50 \% \text { Rec. } \\
\mathrm{N} \text { through FYM }\end{array}$ & 22.5 & 0 & - & 144 & 25.2 & 20.3 \\
\hline $\begin{array}{l}\mathrm{T}_{6}: \mathrm{FYM}\left(10 \mathrm{t} \mathrm{ha}^{-1}\right)+50 \% \text { Rec. } \\
\mathrm{N} \text { through FYM + BF }\end{array}$ & 22.5 & 0 & 5 & 144 & 25.2 & 20.3 \\
\hline $\mathrm{T}_{7}:$ Rec. FYM (10 t ha-1) only & 10 & 0 & - & 64 & 11.2 & 9 \\
\hline $\mathrm{T}_{8}: \operatorname{Rec} . \operatorname{NPK}\left(160: 80: 80 \mathrm{~kg} \mathrm{ha}^{-1}\right)$ & 0 & $\operatorname{Rec}$ & - & 160 & 80 & 80 \\
\hline $\begin{array}{l}\mathrm{T}_{9}: \text { Rec.NPK }\left(160: 80: 80 \mathrm{~kg} \mathrm{ha}^{-1}\right) \\
\text { Rec. FYM }\left(10 \mathrm{t} \mathrm{ha}^{-1}\right)\end{array}$ & +10 & $\operatorname{Rec}$ & - & 234 & 91.2 & 89 \\
\hline
\end{tabular}

FYM=Farm Yard Manure; Rec.=Recommended and ${ }^{*} \mathrm{BF}=$ Bio-fertilizer 
chromatography (Varian 3800 series) using VH-5 column for GC and VH-5 MS column for GCMS $30 \mathrm{~m} \times 0.2 \mathrm{~mm}$ with $0.2 \mathrm{~mm}$ film thickness, oven temperature programmed at $60^{\circ} \mathrm{C}$ for $5 \mathrm{~min}$ then $210^{\circ} \mathrm{C}$ hold for $1 \mathrm{~min}$ then $240^{\circ} \mathrm{C}$ hold it for $1 \mathrm{~min}$ and helium gas as a carrier at $1 \mathrm{ml} \mathrm{min}{ }^{-1}$. Injector and detector temperature were $270^{\circ} \mathrm{C}$ and $240^{\circ} \mathrm{C}$, respectively. Methyl chavicol and Linalool constituents of the oil were identified based on their retention time by comparing with the peak retentions times of those authentic standards obtained from Sigma, Aldrich, Bengaluru and run under identical conditions, then it were estimated in respect to total components and expressed as percentage.

The data recorded from the experiment were analyzed using SAS 9.3 version of the statistical package (SAS Institute Inc 2011). Analysis of variance (ANOVA) was performed using SAS PROC ANOVA procedure. Means were separated using Fisher's protected least significant difference (LSD) test at a probability level of $\mathrm{p}<0.01$.

\section{Results and discussion}

\section{Fresh herbage yield}

Fresh herbage yield of basil differed significantly due to application of different levels of $\mathrm{N}$ through FYM along with and without biofertilizers and inorganic fertilizer in the main crop and ratoon during two years of the experiment. It is evident from the Table 3 that the application of NPK $\left(160: 80: 80 \mathrm{~kg} \mathrm{ha}^{-1}\right)+$ FYM $\left(10 \mathrm{t} \mathrm{ha}^{-1}\right)$ i.e., $\mathrm{T}_{9}$ recorded significantly the highest herbage yield in the main crop (39.96 $\mathrm{t}$ $\mathrm{ha}^{-1}$ ) and ratoon (19.37 tha $\left.\mathrm{th}^{-1}\right)$. The lowest fresh herbage yield per hectare was obtained in $\mathrm{T}_{7}$ applied with FYM (10 t ha-1) alone (22.92 $\left.\mathrm{t} \mathrm{ha}^{-1}\right)$ and in ratoon $\left(10.76 \mathrm{t} \mathrm{ha}^{-1}\right)$. Similar trend was also reflected in total herbage yield of basil. Application of NPK (160:80:80 kg ha-1) + FYM $\left(10 \mathrm{t} \mathrm{ha}^{-1}\right)$ i.e., $\mathrm{T}_{9}$ recorded significantly the highest total herbage yield (59.3 $\mathrm{t} \mathrm{ha}^{-1}$ ) while, the lowest value (33.7 $\left.\mathrm{t} \mathrm{ha}^{-1}\right)$ was recorded in $\mathrm{T}_{7}$ applied with FYM alone.
Nutrients through chemical fertilizer is expected to be more available that reflect on its uptake by plants leading to enhance the growth and yield. On the other hand, combined application of organic manure along with inorganic fertilizer regulated the supply of nutrients which in turn increased the yield (Merestala 1996). Similar findings were also reported by Mohamad et al. (2014) in Ocimum basilicum.

\section{Essential oil content}

Essential oil content plays a key factor in selecting the "adequate" combination of fertilizers in sweet basil cultivation. Application of different levels of FYM, bio-fertilizers and inorganic fertilizer on essential oil content (\%) in the main crop and ratoon showed a significant difference (Table 3). Application of recommended NPK (160:80:80 kg ha-1) + FYM $\left(10 \mathrm{t} \mathrm{ha}^{-1}\right)$ recorded maximum essential oil content ( 0.48 and $0.45 \%$ ) whereas the lowest essential oil content was recorded with recommended dose of FYM alone in $\mathrm{T}_{7}(0.31$ and $0.17 \%$ ) in the main crop and ratoon, respectively. The content of soil nutrient enhanced with application of organic manure, that had positive effect on the growth parameters, herbage and oil yield (Khalid et al. 2006).

\section{Oil yield}

Oil production is the most important parameter in basil farming. The results of different levels of $\mathrm{N}$ through FYM, bio-fertilizers and inorganic fertilizer on oil yield of main crop and ratoon recorded during the two years of the field experiment showed a significant increase in oil production which can be attributed to the increase of nitrogen doses either through organic or inorganic form (Table 3). In the present study, oil yield per hectare increased with the increase of FYM doses, but with application of NPK (160:80:80 $\left.\mathrm{kg} \mathrm{ha}^{-1}\right)+$ FYM (10 $\left.\mathrm{t} \mathrm{ha}^{-1}\right)$ recorded maximum oil yield in the main crop (199.7 $\left.\mathrm{kg} \mathrm{ha}^{-1}\right)$ and in ratoon $\left(107.58 \mathrm{~kg} \mathrm{ha}^{-1}\right)$. The lowest oil yield per hectare was obtained in $\mathrm{T}_{7}$ applied with FYM 
Table 3. Effect of different levels of $\mathrm{N}$ applied through FYM, inorganic fertilizer and bio-fertilizers on fresh herb yield $\left(\mathrm{t} \mathrm{ha}^{-1}\right)$ of basil (Ocimum basilicum $\mathrm{L}$.)

\begin{tabular}{lcccccc}
\hline \multirow{2}{*}{ Treatments } & \multicolumn{5}{c}{ Pooled mean } \\
\cline { 2 - 6 } & \multicolumn{2}{c}{ Fresh herb yield $\left(\mathrm{t} \mathrm{ha}^{-1}\right)$} & Essential oil content $(\%)$ & \multicolumn{2}{c}{ Oil yield $\left(\mathrm{kg} \mathrm{ha}^{-1}\right)$} \\
\cline { 2 - 6 } & Main crop & Ratoon & Main crop & Ratoon & Main crop & Ratoon \\
\hline $\mathrm{T}_{1}$ & $29.62^{\mathrm{D}}$ & 14.18 & $0.42^{\mathrm{C}}$ & $0.32^{\mathrm{D}}$ & $128.7^{\mathrm{D}}$ & $61.10^{\mathrm{D}}$ \\
$\mathrm{T}_{2}$ & $32.78^{\mathrm{C}}$ & $15.45^{\mathrm{C}}$ & $0.45^{\mathrm{B}}$ & $0.41^{\mathrm{C}}$ & $152.6^{\mathrm{C}}$ & $84.02^{\mathrm{C}}$ \\
$\mathrm{T}_{3}$ & $27.06^{\mathrm{EF}}$ & $12.91^{\mathrm{E}}$ & $0.35^{\mathrm{D}}$ & $0.23^{\mathrm{F}}$ & $97.4^{\mathrm{E}}$ & $40.90^{\mathrm{EF}}$ \\
$\mathrm{T}_{4}$ & $29.51^{\mathrm{D}}$ & $14.19^{\mathrm{D}}$ & $0.40^{\mathrm{C}}$ & $0.25^{\mathrm{E}}$ & $126.2^{\mathrm{D}}$ & $48.28^{\mathrm{E}}$ \\
$\mathrm{T}_{5}$ & $25.47^{\mathrm{F}}$ & $11.54^{\mathrm{F}}$ & $0.35^{\mathrm{D}}$ & $0.22^{\mathrm{FG}}$ & $90.2^{\mathrm{E}}$ & $35.81^{\mathrm{FG}}$ \\
$\mathrm{T}_{6}$ & $27.70^{\mathrm{E}}$ & $12.54^{\mathrm{E}}$ & $0.34^{\mathrm{D}}$ & $0.21^{\mathrm{G}}$ & $97.6^{\mathrm{E}}$ & $38.91^{\mathrm{EF}}$ \\
$\mathrm{T}_{7}$ & $22.92^{\mathrm{G}}$ & $10.76^{\mathrm{G}}$ & $0.31^{\mathrm{E}}$ & $0.17^{\mathrm{H}}$ & $73.8^{\mathrm{F}}$ & $26.94^{\mathrm{G}}$ \\
$\mathrm{T}_{8}$ & $36.83^{\mathrm{B}}$ & $17.25^{\mathrm{B}}$ & $0.46^{\mathrm{AB}}$ & $0.43^{\mathrm{B}}$ & $177.9^{\mathrm{B}}$ & $96.13^{\mathrm{B}}$ \\
$\mathrm{T}_{9}$ & $39.95^{\mathrm{A}}$ & $19.37^{\mathrm{A}}$ & $0.48^{\mathrm{A}}$ & $0.45^{\mathrm{A}}$ & $199.7^{\mathrm{A}}$ & $107.58^{\mathrm{A}}$ \\
Mean & 30.21 & 14.25 & 0.39 & 0.30 & 127.1 & 59.96 \\
CV $(\%)$ & 3.07 & 1.67 & 2.75 & 3.41 & 3.81 & 10.17 \\
LSD (P<0.05) & 1.61 & 0.39 & 0.018 & 0.017 & 8.39 & 10.55 \\
\hline
\end{tabular}

Legend: FYM=Farm Yard Manure; Rec.=Recommended; BF=Bio-fertilizer

(10 $\left.\mathrm{t} \mathrm{ha}^{-1}\right)$ alone in the main crop $\left(73.8 \mathrm{~kg} \mathrm{ha}^{-1}\right)$ and in ratoon $\left(26.94 \mathrm{~kg} \mathrm{ha}^{-1}\right)$. Highest total oil yield was observed in $\mathrm{T}_{9}$ applied with NPK $\left(160: 80: 80 \mathrm{~kg} \mathrm{ha}^{-1}\right)+$ FYM $\left(10 \mathrm{t} \mathrm{ha}^{-1}\right)$ and the lowest total oil yield was recorded in $\mathrm{T}_{7}$ applied with FYM alone. Integrated nutrient management improve the chemical, physical and biological soil proprieties that reflect positively on plant growth and oil yield (Patra et al. 2000). These results are similar to the observation of Zeinab (2005), Dadkh (2012) and El-naggar et al. (2015).

\section{Oil quality}

The most important volatile molecules identified in basil essential oil are methyl chavicol as phenolic compound and linalool as monoterpene (Mondello et al. 2002) and Sajjadi (2006). The quality standard of the essential oil in basil is determined by polyphenols concentration (Toor 2006). Comparing the integration peaks, there was a significant difference in methyl chavicol percentage within the treatments. The results in (Table 4) showed that $\mathrm{T}_{9}$ applied with NPK (160:80:80 $\left.\mathrm{kg} \mathrm{ha}^{-1}\right)+$ FYM $\left(10\right.$ t ha $\left.^{-1}\right)$ recorded the highest percentage of methyl chavicol in the main crop of 2015 $(52.3 \%)$ while, in the main crop of 2016 , application of FYM (10 t ha $\left.\mathrm{h}^{-1}\right)+100 \%$ recommended $\mathrm{N}$ through $\mathrm{FYM}+$ bio fertilizers i.e., $\mathrm{T}_{2}$ recorded maximum methyl chavicol percentage $(63.78 \%)$. In ratoon, application of FYM $\left(10 \mathrm{t} \mathrm{ha}^{-1}\right)+100 \%$ recommended $\mathrm{N}$ through FYM + bio fertilizers recorded the highest methyl chavicol percentage (59.39 and $59.67 \%$ ) during first and second year, respectively. The lowest percentage of methyl chavicol was recorded with $\mathrm{T}_{7}(40.05$ and $46.2 \%)$ in main crop and in ratoon (40.22 and $41.49 \%$ ) of 2015 and 2016, respectively.

Linalool content increased with dosage of nutrients application as shown in (Table 6). Application of NPK (160:80:80 kg ha-1) + FYM $\left(10 \mathrm{t} \mathrm{ha}^{-1}\right)$ i.e., $\mathrm{T}_{9}$ recorded the highest percentage of Linalool in the main crop (25.29 and $22.88 \%$ ) and ratoon (26.59 and $25.19 \%$ ). While, the lowest Linalool percentage was recorded in $\mathrm{T}_{7}$ of the main crop (19.20 and $15.20 \%$ ) and ratoon 
Table 4. Content of principle ingredient in basil essential oil (\%) as influenced by different levels of $\mathrm{N}$ applied through FYM, bio-fertilizers and inorganic fertilizer

\begin{tabular}{lcccccccc}
\hline & Treatments & \multicolumn{3}{c}{ Methyl chavicol (\%) } & \multicolumn{4}{c}{ Linalool (\%) } \\
\cline { 2 - 8 } & \multicolumn{3}{c}{2015} & \multicolumn{2}{c}{2016} & \multicolumn{2}{c}{2015} & \multicolumn{2}{c}{2016} \\
\cline { 2 - 8 } & Main crop & Ratoon & Main crop & Ratoon & Main crop & Ratoon & Main crop & Ratoon \\
\hline $\mathrm{T}_{1}$ & 45.49 & 43.84 & 60.07 & 50.23 & 20.01 & 21.46 & 23.06 & 20.19 \\
$\mathrm{~T}_{2}$ & 49.39 & 59.39 & 63.78 & 59.67 & 22.3 & 20.07 & 21.37 & 23.48 \\
$\mathrm{~T}_{3}$ & 41.42 & 45.60 & 57.57 & 50.15 & 20.7 & 19.08 & 20.76 & 19.60 \\
$\mathrm{~T}_{4}$ & 50.83 & 59.23 & 62.92 & 55.38 & 21.13 & 20.14 & 21.11 & 22.71 \\
$\mathrm{~T}_{5}$ & 40.39 & 42.28 & 56.08 & 43.28 & 19.56 & 18.43 & 19.81 & 17.67 \\
$\mathrm{~T}_{6}$ & 46.06 & 52.66 & 59.67 & 51.22 & 20.49 & 21.16 & 17.59 & 20.25 \\
$\mathrm{~T}_{7}$ & 40.05 & 40.22 & 46.20 & 41.49 & 19.20 & 15.20 & 15.28 & 16.25 \\
$\mathrm{~T}_{8}$ & 42.5 & 54.60 & 49.52 & 53.90 & 23.44 & 21.47 & 22.22 & 24.22 \\
$\mathrm{~T}_{9}$ & 52.31 & 45.50 & 52.62 & 44.17 & 25.29 & 22.88 & 26.59 & 25.19 \\
\hline
\end{tabular}

(15.28 and 16.25\%) during 2015 and 2016, respectively. Secondary metabolism such as phenolics increases in stress condition, this may justify the highest percentage of methyl chavicol as a result of organic manure application (Sousa et al. 2005). Adding biofertilizers resulted in an increase in phenolics content because it promotes roots growth and making the nutrients in available form for plant absorption (Javanmardi et al. 2002). Thus microorganisms can fix $\mathrm{N}_{2}$ and supply it to the plant they synthesis siderophores which play a key role for solublization of minerals such as phosphorus and iron which become readily available for plants.

The outcome of the present investigation revealed that the maximum fresh herbage yield, essential oil content, oil yield and its best quality was obtained with application of recommended FYM $\left(10 \mathrm{t} \mathrm{ha}^{-1}\right)+$ recommended NPK (160:80:80 kg ha-1) for both main as well as in ratoon basil crop. Addition of biofertilizers also increased the content of principle ingredient in basil essential oil (methyl chavicol and linalool). Hence, the incorporation of full dose of recommended FYM along with $50 \%$ of recommended $\mathrm{N}$ through inorganic fertilizer as basal and the remaining fifty per cent as top dressing at 45 days after transplanting may be recommended for basil crop to realize higher herbage and oil yield and better oil quality in sweet basil.

\section{References}

Amran K A A 2013 Physiological studies on Pelargonium graveolens L plant. Ph.D. Thesis, Fac. Agric., Moshtohor, Benha University, Egypt.

Anwar M, Patra D D, Chand S, Alpesh K, Naqvi A A \& Hanuja S P S 2007 Effect of organic manures and inorganic fertilizer on growth, herb and yield, nutrient accumulation, and oil quality French basil. Comm. Soil Sci. Plant Anal. 36: 1737-1746.

Biesiada A \& Ku A 2010 The effect of nitrogen fertilization and irrigation on yielding and nutritional status of sweet basil (Ocimum basilicum L.). Acta Sci. Pol. Hortorum Cultus. 9: 3-12.

Dadkh A 2012 Effect of chemicals and bio-fertilizer on yield, growth parameters and essential oil contents of fennel (Foeniculum vulgare). J. Med. Plants By-Prod. 2: 101-105.

Daneshian A, Gurbuz B, Cosge B \& Ipek A 2009 Chemical components of essential oils from basil (Ocimum basilicum L.) grown at different nitrogen levels. Internat. J. Nat. Engg. Sci. 3: 8-12. 
El-khyat L A S 2013 Effect of chemical and bio fertilizer on growth and chemical composition of rosemary plants. M.Sc. Thesis, Fac. Agric. Moshtohor Benha University, Egypt.

Javanmardi J, Khalighi A, Kashi A, Bais H P \& Vivanco J M 2002 Chemical characterization of basil (Ocimum basilicum L.) found in local accessions and used in traditional medicines in Iran. J. Agril. Food Chem. 50: 5878-5883.

Khalid K H, Hendawy S F \& El-Gezawy E 2006 Ocimum basilium L. production under organic faming. Res. J. Agri. Biol. Sci. 2: 25-32.

Merestala T 1996 Abstract bibliography of researches of bio and organic fertilizers at Benguet State University 1975-1996. La Trinidad, Benguet, 53p.

Mohammad K, Mohsen J \& Forough D 2014 The effects of organic and chemical fertilizers on yield and essential oil percentage of vegetative parts of (Ocimum basilicum L.). 59 $9^{\text {th }}$ International Congress and Annual Meeting of the Society for Medicinal Plant and Natural Product Research, p.363-372.

Mondello L, Zappia G, Cotroneo A, Bonaccorsi I, Chowdhury JU, Yusuf M \& Dugo G 2002 Studies on the essential oil-bearing plants of Bangladesh. Part VIII. Composition of some Ocimum oils O. basilicum L. var. purpurascens; O. sanctum L. green; O.sanctum L. purple; O. americanum L., citral type; $O$. americanum L., camphor type. Flav. Fragr. J. 17: 335-340.

Nour A H, Elhussein S A, Osman N A, Ahmed N E, Abduelrahman A A \& Yusoff M M 2009 Antibacterial activity of the essential oils of Sudanese accessions of basil (Ocimum basilicum L.). J. Appl. Sci. 9: 4161-4167.
Patra D D, Anwar M \& Chand S 2000 Integrated nutrient management and waste recycling for restoring soil fertility and productivity in Japanese mint (Mentha arvensis) and mustard (Brassica juncea) sequence in Utter Pardesh, India. Agri. Ecosys. Environ. 80: 267-275.

Reza Haj M, Seyed Hadi S, Mohsen F \& Mohammad T 2015 Influence of nitrogen fertilizer and vermicompost application on flower yield and essential oil of Chamomile (Matricaria chamomile L.). J. Chem. Health Risks 5: 235244.

Sajjadi S E 2006 Analysis of the essential oils of two cultivated basil (Ocimum basilicum L.) from Iran. Daru. 14: 128-130.

Sekar K, Thangaraj S, Saravana Babu S, Harisaranraj R \& Suresh K 2009 Phytochemical constituent and antioxidant activity of extract from the leaves of Ocimum basilicum. J. Phytol. 1: 408-413.

Shahram S \& Ordookhani K 2011 Organic and bio fertilizers as a good substitute for inorganic fertilizers in medicinal plants farming. Australian J. Basic Appl. Sci. 5: 1330-1333.

Sousa C, Valentao P, Rangel J, Lopes G \& Andrade P B 2005 Influence of two fertilization regimens on the amounts of organic acids and phenolic compounds of tronchuda cabbage (Brassica oleracea L. var. costata DC). J. Agri. Food Chem. 53: 9128-9132.

Toor R K 2006 Influence of different types of fertilizers on the major antioxidant components of tomatoes. J. Food Comp. Anal. 19: 20-27.

Zeinab S 2005 Physiological Studies on Basil Plant. Ph.D. Thesis submitted to the graduate division of the University of al-Mansoura, Cairo. 
Journal of Spices and Aromatic Crops

Vol. 27 (1) : 45-53 (2018)

doi : 10.25081/josac.2018.v27.i1.1014

Annual and monthly rainfall trend in plantation and spice farming Western Ghats districts

K Kandiannan*, K S Krishnamurthy, C K Thankamani \& S J Ankegowda ${ }^{1}$

ICAR-Indian Institute of Spices Research, Kozhikode - 673012, Kerala.

*E-mail: kandiannan@gmail.com

Received 21 April 2018; Revised 18 May 2018; Accepted 19 May 2018

\begin{abstract}
Rainfall analysis of important plantation and spices producing districts such as The Nilgiris (Tamil Nadu), Kodagu (Karnataka) Idukki (Kerala) and Wayanad (Kerala) with 100 years data (1901 to 2000) obtained from the India Meteorological Department (IMD), Pune indicated that mean annual rainfall were $1839.7 \mathrm{~mm}, 2715.7 \mathrm{~mm}, 2979.4 \mathrm{~mm}$ and $3381.0 \mathrm{~mm}$ with a coefficient of variation $(\mathrm{CV})$ of $16.0 \%, 17.0 \%, 25.8 \%$ and $19.6 \%$, respectively. The contribution of southwest monsoon(June-September) to the annual rainfall in these districts were $80.3 \%$ (Wayanad), $78.9 \%$ (Kodagu), 65.2\% (Idukki) and 56.3\% (The Nilgiris) with corresponding CV of 24.1\%, 20.6\%, $32.5 \%$, and $24.6 \%$, respectively. The declining trend in mean annual rainfall was noticed for Idukki, Wayanad and The Nilgiris, whereas, for Kodagu, it was stable. The change was significant in Wayanad and The Nilgiris. Similar trend was also observed for the southwest monsoon rainfall. The maximum decline in annual and southwest monsoon rainfall was noticed in The Nilgiris followed by Wayanad. Pre and post monsoon rainfall receipts were comparatively less with high inter-annual variations. The pre-monsoon (March-May) receipt and its coefficient of variation (CV) was $252.4 \mathrm{~mm} \& 20.6 \%$ (Kodagu), $360.9 \mathrm{~mm} \& 36.5 \%$ (Idukki), $251.7 \mathrm{~mm}$ \& 36.6\% (The Nilgiris) and $274.2 \mathrm{~mm} \& 54.2 \%$ (Wayanad) $252.2 \mathrm{~mm}$. The post monsoon (October-December) rain was maximum in Idukki $548.1 \mathrm{~mm}$ (CV 27.9\%) followed by The Nilgiris $503.4 \mathrm{~mm}(\mathrm{CV} 31.3 \%$ ), Wayanad, $333.1 \mathrm{~mm}(\mathrm{CV} 37.8 \%$ ) and Kodagu $310.5 \mathrm{~mm}$ (CV 32.7\%). In all these districts there was a declining trend in the pre-monsoon rain with maximum decline in The Nilgiris. Similar declining trend was also observed in post-monsoon rain except for The Nilgiris, where the trend has been increasing. Overall, the study gives an indication that there was a spatial and temporal variation in rainfall amounts. The maximum decline in annual rainfall and the southwest monsoon was observed in The Nilgiris and Wayanad. July was the rainiest month in all the districts studied. Significant negative trend was asscoaited with The Nilgiris for January, May, June, July and August months. Whereas, in Kodagu, no significant trend was observed for mean monthly rainfall, except for August. In Idukki, significant negative changes were noticed for January, March, October and December rainfall. Monthly rainfall of January, March, April and July monthly rainfall were showed significant negative trend in Wayanad,. These negative trends across important plantation and spices producing districts of the Western Ghats would affect not only the agricultural economy of this sector but also water resources.
\end{abstract}

Keywords: annual and monthly rainfall trend, rainfall analysis, plantation and spice crops, western ghats districts

${ }^{1}$ Regional Station, ICAR-Indian Institute of Spices Research, Appangala, Madikeri, Kodagu-571201, Karnataka. 


\section{Introduction}

Western Ghats (WG) in India are internationally recognized as a region of immense global importance for the conservation of biological diversity, besides striking geological, cultural and aesthetic values. The WG Mountains are considered older than the Himalayas. A significant characteristic of the WG is the exceptionally high level of biological diversity and endemism. The entire mountain chain is recognized as one of the world's eight 'hottest hotspots' of biological diversity along with Sri Lanka. The forests of the WG include some of the best representatives of non equatorial tropical evergreen forests in the world (http://whc.unesco.org/en/list/1342). The WG constitute a practically unbroken hill chain (with the exception of the Palakkad Gap) or escarpment running roughly in a northsouth direction, for about $1500 \mathrm{~km}$ parallel to the Arabian sea coast, from the river Tapi (about $21^{\circ} 16^{\prime} \mathrm{N}$ ) down to just short of Kanyakumari (about $8^{\circ} 19^{\prime} \mathrm{N}$ ) at the tip of the Indian peninsula. The high ranges of the WG are crucial for the security of water resources of the peninsular India (WGEEP 2011), runs through Gujarat, Maharashtra, Goa, Karnataka, Kerala and Tamil Nadu. The definition of WG and detailed boundaries are described in the report of the Western Ghats Ecology Expert Panel (WGEEP 2011). The district boundaries do not, by and large, coincide with limits of WG. The majority of districts also include either west coast or western peninsular tract regions along with WG areas. Only four districts viz., Kodagu from Karnataka, The Nilgiris from Tamil Nadu, Wayanad and Idukki from Kerala are fully in the Western Ghats region. These districts contribute significantly to the plantation and spice economy of the country and houses main plantation crops like tea, coffee, rubber, and spice crops such as cardamom, black pepper and ginger. As these crops are mostly grown as rainfed, analysis of rainfall and identification of trend is essential for designing proper crop management plans in the light of current climatic change.

\section{Materials and methods}

Four exclusive WG districts viz., Kodagu from Karnataka, The Nilgiris from Tamil Nadu, Wayanad and Idukki from Kerala were selected for the study. These are high altitude districts have dense forest cover and enjoy higher rainfall. The altitude of Wayanad district is 700 to 1,200 masl lies in the latitude between $11^{\circ} 27^{\prime}$ and $15^{\circ} 58^{\prime} \mathrm{N}$ and the longitude $75^{\circ} 47^{\prime}$ and $70^{\circ}$ $27^{\prime}$ E. Idukki's mean altitude is $1,200 \mathrm{~m}$ but many peaks rise above 2000 masl and the district lies between $9^{\circ} 15^{\prime}$ and $10^{\circ} 2^{\prime} \mathrm{N}$ and $76^{\circ} 37^{\prime}$ to $77^{\circ} 25^{\prime} \mathrm{E}$. The Nilgiris altitude varies between $300 \mathrm{~m}$ and 2,789 masl situated between $11^{\circ} 08^{\prime}$ to $11^{\circ} 37^{\prime} \mathrm{N}$ and $76^{\circ} 27^{\prime}$ to $77^{\circ} 4^{\prime}$ E longitude. Kodagu has the lowest elevation range between 900 to 1,750 masl located between $11^{\circ} 56^{\prime}$ to $12^{\circ} 56^{\prime} \mathrm{N}$ latitude and $75^{\circ} 22^{\prime}$ to $76^{\circ} 11^{\prime} \mathrm{E}$ longitude. The rainfall data of these districts for hundred years (1901 to 2000) were purchased from IMD, Pune and used for rainfall analysis.

A non-parametric Mann-Kendall test was used for the detection of rainfall trends (Mann, 1945; Kendall, 1975). Test was performed using free trial version of XLSTAT software. The MannKendall Statistic (S) measures the trends of rainfall series over time. Positive values indicate an increase in constituent concentrations over time, whereas negative values denote a decrease in constituent concentrations over time. The strength of the trend is proportional to the magnitude of the Mann-Kendall Statistic (i.e., large magnitudes indicate a strong trend). If a linear trend is present in a time series, then the true slope (change per unit time) can be estimated by using a simple non-parametric procedure developed by Sen (1968a and b). According to this test, the null hypothesis $\mathrm{H} 0$ assumes that there is no trend (the data is independent and randomly ordered) and this is tested against the alternative hypothesis $\mathrm{H} 1$, which assumes that there is a trend at $\mathrm{P} \mathrm{d"0.05.}$

\section{Results and discussion}

Major plantation and spice crops like tea, coffee; black pepper and cardamom are produced in 
higher elevation of the WG districts where their relative spread and yield are high compared to lower elevation areas or plains. These crops used to grow under rainfed condition as the rainfall receipt was high and distribution also was good. The yield of these crops now often fluctuates mainly due to higher inter-annual variability in rainfall. Results of study conducted to find out the rainfall trend of potential plantation and spice producing WG districts viz., Idukki and Wayanad in Kerala, The Nilgiris in Tamil Nadu and Kodagu (Coorg) in Karnataka are presented and discussed here.

\section{The Nilgiris}

Mean annual rainfall was $1839.7 \mathrm{~mm}$ (Table 1) with a coefficient of variation of $16.0 \%$. Monthly rainfall pattern from May through November has received above $100 \mathrm{~mm}$ with July being the rainiest month $(366.9 \mathrm{~mm})$ with its high variability $(43.5 \%$ C.V.) contributes $19.95 \%$ to annual rainfall. The rainfall from the southwest and northeast monsoons as well as summer rainfall were correspondingly $1035.7 \mathrm{~mm}$, $503.4 \mathrm{~mm}, 251.7 \mathrm{~mm}$ that accounts $56.3 \%$, $27.36 \%, 13.69 \%$ of annual rainfall, respectively. Mann-Kendall Statistics (S) and Sen's slope value have shown that there was a negative trend for monthly rainfall except in November and December. The annual rainfall also manifested a negative trend. The value of ' $p$ ' presented in the Table 1 hinted that there exists a significant trend for monthly rainfall of January, May, June, July, August as well as annual rainfall. Raju et al. (2013) have classified The Nilgiris climate as semi-arid to humid type. Previously, Manorama et al.(2007) and Manivannan et al. (2016) examined The Nilgiris rainfall data for crop planning but not looked into the trend identification. Manorama et al.(2007) analyzed thirty years (1971 to 2000) observed rainfall data and suggested appropriate planting time for root crops like potato, cabbage and carrot during the third week of April and the end of August following crop rotation. Manivannan et al. (2016) stated that a major part of The Nilgiris is covered under forest (56\%) followed by plantation

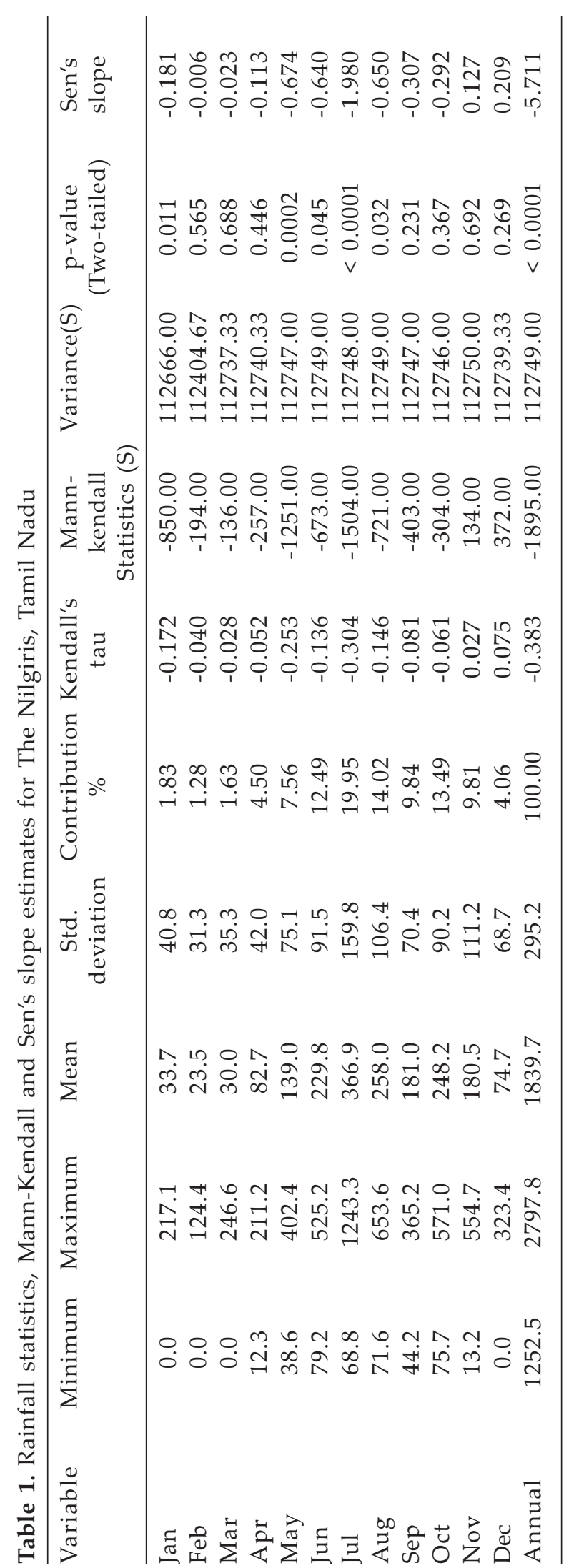


(20\%) like tea, coffee and the remaining areas are used for vegetables. They also stressed that many places experience sever water scarcity and moisture stress during summer months due to frequent dry spells even during monsoon periods that adversely affects the productivity of plantations and vegetable crops in this region. They also strongly advocated strengthening water harvesting structures to capture excess rainfall received between $20^{\text {th }}$ and $45^{\text {th }}$ weeks and utilize for farming.

\section{Kodagu}

Mean annual rainfall of this district was $2715.7 \mathrm{~mm}$ (Table 2) with $17.0 \%$ C.V. Monthly rainfall pattern signaled that receipt was less during winter and summer months and July is considered the rainiest month $(876.6 \mathrm{~mm})$ with a coefficient of variation of $34.8 \%$. The rainfall amounts from southwest and northeast monsoons as well as summer rainfall were $2143.1 \mathrm{~mm}, 310.5 \mathrm{~mm}, 252.4 \mathrm{~mm}$ that respectively accounts $78.9 \%, 11.4 \%, 9.3 \%$ of annual rainfall. The rainfall receipt between May and October was more than $100 \mathrm{~mm}$ per month. Sufficient soil moisture would be available for crop production during these months. MannKendall Statistics (S) and Sen's slope analysis have indicated that there was a positive trend in annual rainfall. Although few months showed negative trend in monthly rainfall, the ' $\mathrm{p}$ ' values proved that as such there was no significant trend in monthly rainfall except for August where ' $\mathrm{p}$ ' value was less than $0.05 \%$. Raju et al. (2013) have classified the Kodagu climate as per-humid to humid type. Increasing rainfall trend was also reported by Mallappa et al. (2015) for Kodagu district. The district is popular for cardamom and coffee + black pepper cropping system and contributes substantially for national production. Ankegowda et al. (2010) have identified the length of growing period for this region between $21^{\text {st }}$ and $43^{\text {rd }}$ week ( $21^{\text {st }}$ June to $28^{\text {th }}$ November) with more dependable rainfall with lesser C.V. and suggested crop production operations to be carried out during this period for various crops.

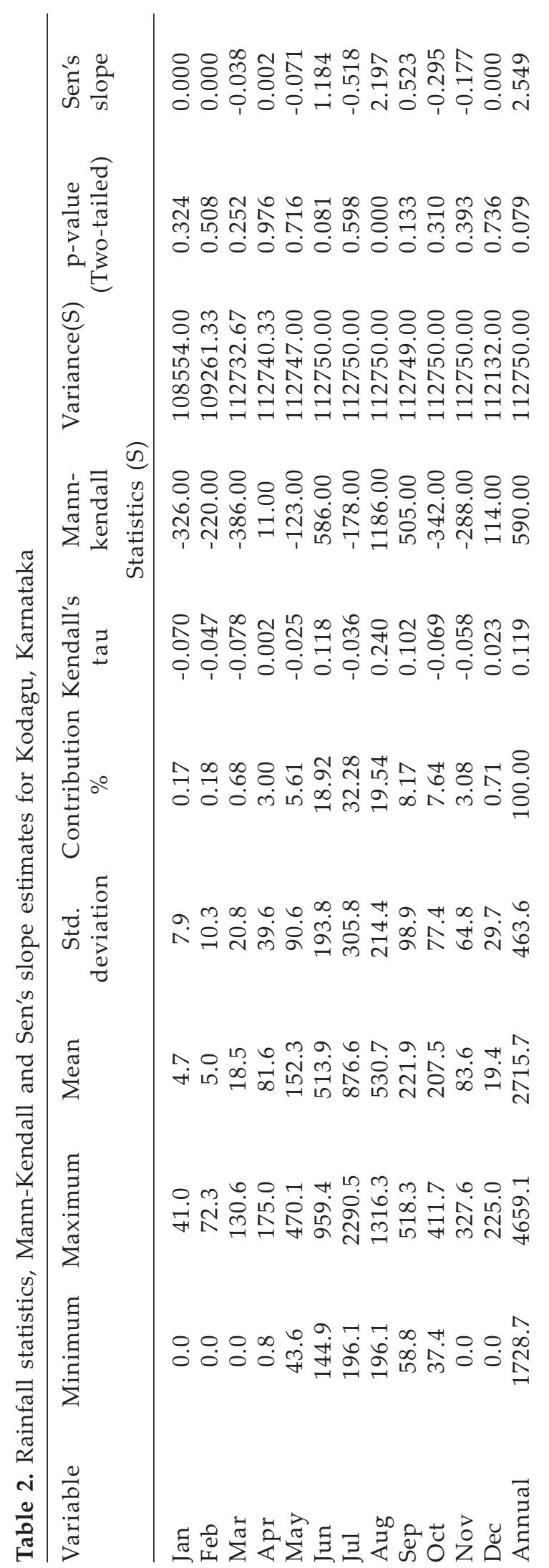


Idukki

Idukki's mean annual rainfall was $2979.4 \mathrm{~mm}$ (Table 3) with very high percentage of C.V. of (25.8\%). Highest rainfall among months was received by July $(673.7 \mathrm{~mm})$ with $45.7 \%$ C.V. The monthly rainfall between May and October was above $100 \mathrm{~mm}$ and contribution to annual rainfall was maximum $(22.61 \%)$ for July followed by June $18.92 \%$ and August (14.77\%). The rainfall from southwest and northeast monsoons as well as summer rainfall were $1943.9 \mathrm{~mm}, 548.1 \mathrm{~mm}, 360.9 \mathrm{~mm}$ that accounted $65.2 \%, 18.4 \%, 12.1 \%$ of annual rainfall respectively. Mann-Kendall Statistics (S) and Sen's slope results have indicated that there was a negative trend in monthly and annual rainfall except August (Table 3) and the trend was significant for months of January, March, October and December with ' $p$ ' less than $0.05 \%$. Raju et al. (2013) have classified the Idukki's climate as Per-humid to humid type. Krishnakumar and Rao (2006) have analysed the long term rainfall data (1871-2000) of Kerala and found that the failure of northeast and premonsoon rainfall lead to droughts in $65 \%$ of the years during summer that has affected the most plantation crops and they attributed this to man-made interventions into the ecological balance particularly during the last 50 years. Krishnakumar \& Rao (2008) have argued that the monthly rainfall over Kerala for the period 1871 to 1994 showed an increasing tendency during October and November but a decreasing trend was shown by December. Similar trend was more evident since 1961 onwards. Archana et al. (2014) have noticed a decreasing monthly and annual rainfall trend in Kerala which they attribute to anthropogenic green house gas (GHG) emissions due to increased fossil fuel use, land-use change due to urbanisation and deforestation, proliferation in transportation associated atmospheric pollutants. Murugan et al. $(2000 ; 2009 ; 2011)$ have reported the changes in rainfall trends of this region and discussed possible negative impacts on crops and plants as well as ecosystem hydrology because cardamom, coffee, tea and native forest plants are highly sensitive to precipitation changes.

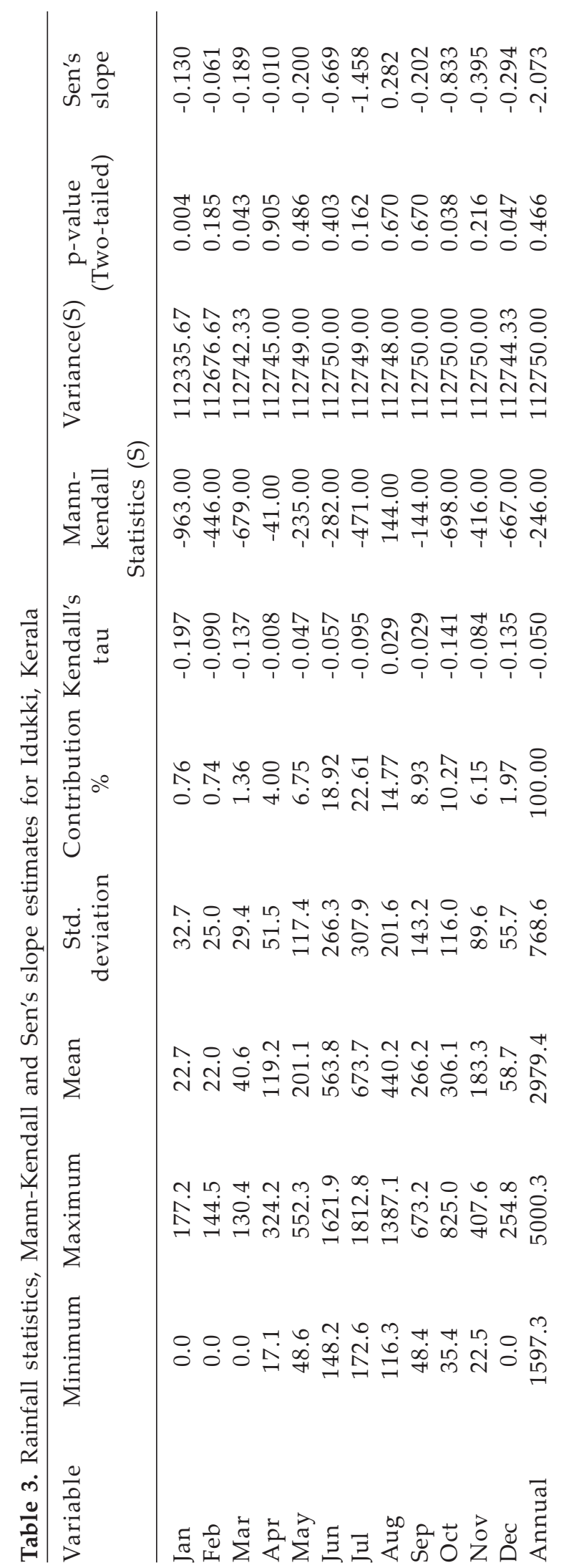




\section{Wayanad}

Annual rainfall of Wayanad district varied between $2321.2 \mathrm{~mm}$ and $6142.0 \mathrm{~mm}$ with a mean of $3381.0 \mathrm{~mm}$ (Table 4 ) having the second lowest C.V. of $19.6 \%$ among the districts studied. Mean monthly rainfall of July was the highest $(1131.3 \mathrm{~mm})$ with $41.4 \%$ C.V. that contributed $33.46 \%$ to the annual rainfall. The contribution of June and August months rainfall were $21.53 \%$ and $18.40 \%$ respectively to the annual rainfall. The rainfall from southwest and northeast monsoons and summer rainfall were $2716.6 \mathrm{~mm}, 333.1 \mathrm{~mm}, 274.2 \mathrm{~mm}$ that shared $80.3 \%, 9.85 \%, 8.11 \%$ of the annual rainfall, correspondingly. More than $100 \mathrm{~mm}$ rainfall has been received during May to October months. Mann-Kendall Statistics (S) and Sen's slope trend have indicated that there was a significant negative trend in monthly rainfall for January, March, April, July. The annual rainfall recorded ' $\mathrm{p}$ ' values less than critical $0.05 \%$. Raju et al. (2013) have classified the Wayanad climate as Per-humid to moist subhumid type. Rao \& Krishnakumar (2005) have indicated that there was no change in the onset of monsoon over Kerala ( $1^{\text {st }}$ June \pm 7 days $)$ over a period of time (1871-2004), and only 28.2 percent of the years only fell under early or late monsoon years. Further, it was also noticed that if the monsoon was early that season would receive deficit rainfall, and no trend was seen when the monsoon was late. They also reported that there was decline of $6.8 \%$ in annual rainfall over the period which was more evident in monsoon rainfall since the last sixty years. Similar negative trend for the district was reported by Sushant et al. (2015). In another study by Kumar \& Srinath (2011) showed that weakening of the early phase of the southwest monsoon precipitation; increasing polarisation of daily rainfall and more frequent heavy rainfall days that hastened maturation of a variety of crops. Gaetaniello et al. (2014) have observed that the variability in rainfall was more influential than the air temperature fluctuation in this district. During the study period (1951 to 2008), the monsoon rainfall decreased, while maximum and minimum daily temperature increased and farmers perceived

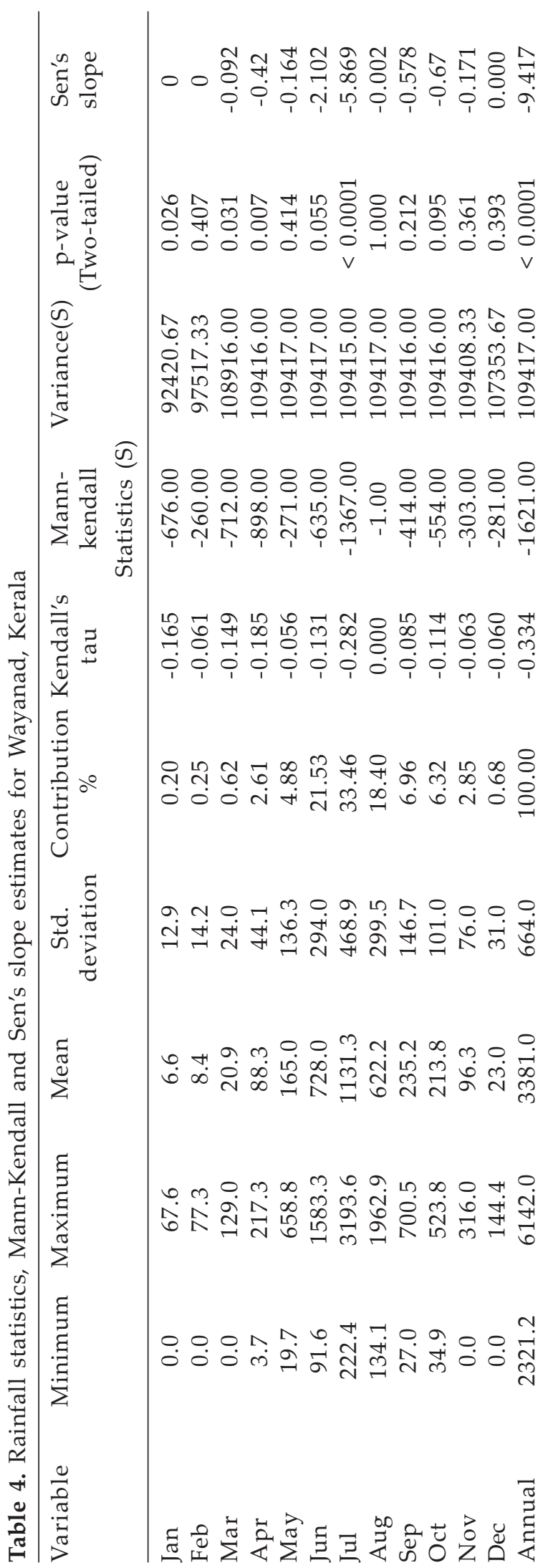


that drought was the major climatic challenge to existing farming practices. Kandiannan et al. (2008) analysed the 26 years (1980-2005) rainfall of high rainfall tract of northern agroclimatic zone of Kerala and observed that coefficient of variations for monthly rainfall from April to November was less than $100 \%$ and it is considered more dependable rainfall for crop production in this region. They also reported that the rainfall receipt from December to March was less and crops would suffer for want of
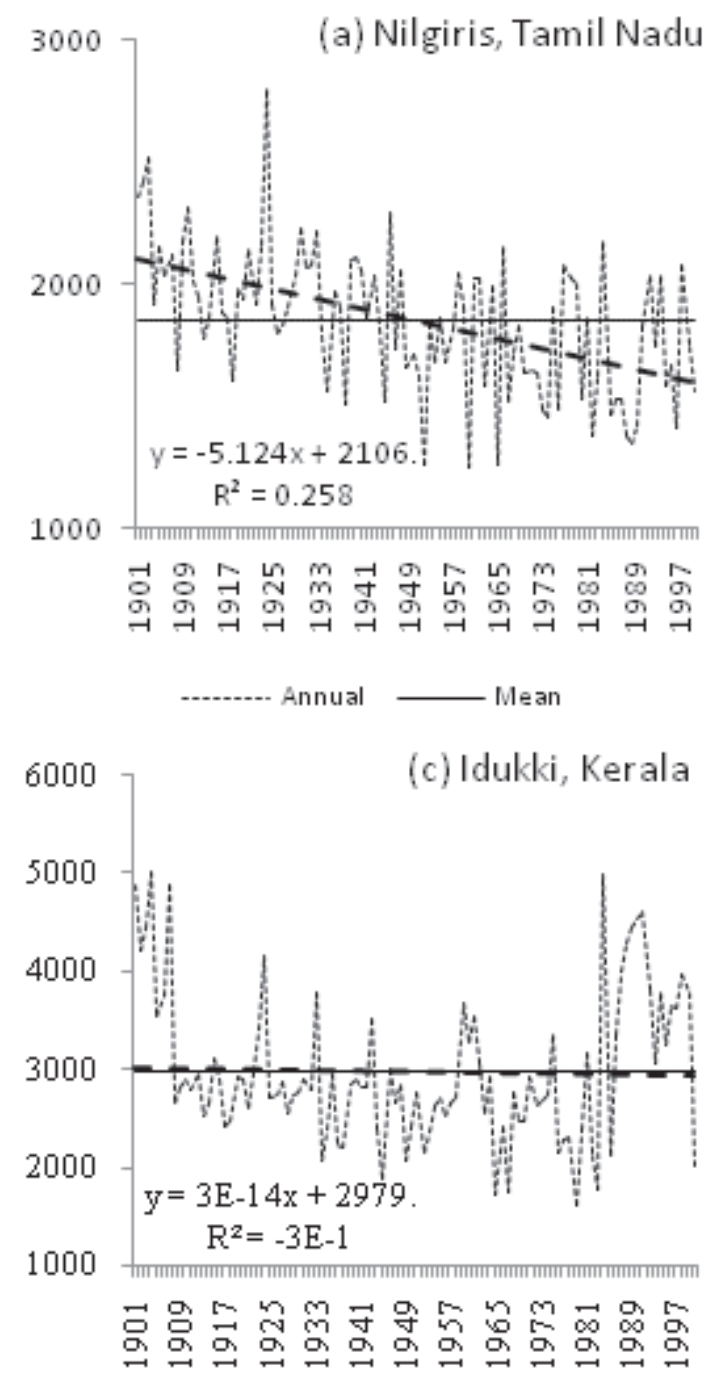

moisture and suggested for adequate soil water conservation measures. Krishnakumar et al. (2009) showed that there was a significant decreasing trend in southwest monsoon rainfall while increase in post-monsoon season over the State of Kerala.

Rainfall analysis of exclusive WG districts indicated that there was a temporal and spatial variation in rainfall receipt among these districts and high mean annual rainfall was
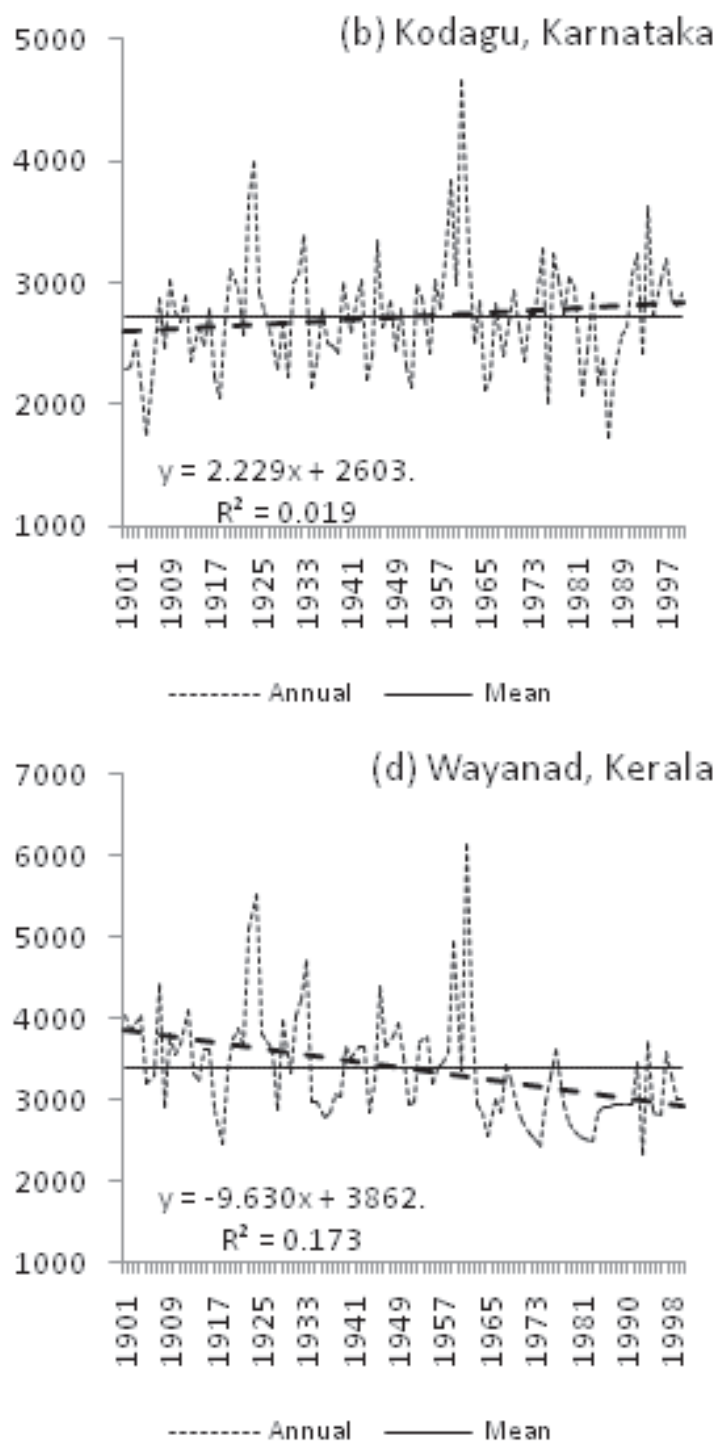

Fig. 1. Annual rainfall trend in exclusive Westen ghats districts (Nilgiris), (b) Kodagu, (c) Idukki, (d) Wayanad 
received in Wayanad $(3381.0 \mathrm{~mm})$ followed by Idukki (2979.4 mm), Kodagu (2715.7 mm) and Nilgiris (1839.7). Decreasing trend in mean annual rainfall was noticed in Idukki, Wayanad and The Nilgiris, whereas in Kodagu the annual rainfall was stable (Fig. 1). The trend was significant for The Nilgiris and Wayanad. Similar trend was also observed for southwest monsoon rainfall. The decline in annual rainfall and the southwest monsoon was noticed for The Nilgiris and Wayanad. July was the rainiest month in all these districts. The negative trend was significant for January, May, June, July and August for the The Nilgiris, whereas in Kodagu no significant trend for mean monthly rainfall was observed except for August. At Idukki, significant negative changes were noticed for January, March, October and December months rainfall; whereas in Wayanad, January, March, April and July months rainfall showed significant negative trend. These negative trends in these important plantation and spices producing districts of the WG would affect the agricultural economy and hydrological systems.

\section{Acknowledgements}

The authors are grateful to The Director, ICARIndian Institute of Spices Research, Kozhikode for the facilities and support. They also thankful to Prof (Dr.) M. Murugan, Professor \& Head, KAU - Cardamom Research Station, Pampadumpara for offering valuable comments on the paper.

\section{References}

Ankegowda S J, Kandiannan K \& Venugopal M N 2010 Rainfall and temperature trends- A tool for crop planning. J. Plantn. Crops 38: 5761.

Archana N, Joseph A K \& Nair K S 2014 Spatiotemporal analysis of rainfall trends over a maritime state (Kerala) of India during the last 100 years. Atmospheric Envt. 88: 123132.

Kumar D \& Srinath P 2011 Climate Trends in Wayanad: Voices from the Community. UGC Sponsored National Seminar on
'Recent Trends in Climate \& Impact of Climate Change on South-West India' at the St. Joseph's College, Devagiri, Kozhikode, Kerala. Available at https://www.academia. edu/1641561/Climate Trends in Wayanad Voices from the Community (Accessed on 25-8-2016).

Gaetaniello A, Nidhi N, Shradha S \& Prasad K V D 2014 Examining the Influence of Climate Change Impacts on Agrobiodiversity, Land Use Change and Communities: An Empirical Experience from WayanadKerala, India (pp.201-213). In: Anisa B Khan (Ed.) e-proceedings Green India: Strategic knowledge for combating climatic change: Prospects \& Challenges. Pondicherry University, Pondicherry and Excel India Publishers, New Delhi.

http://whc.unesco.org/en/list/1342 World heritage list - Western Ghats (accessed on 25-8-2016).

Kandiannan K, Thankamani C K \& Mathew P A 2008 Analysis of rainfall of the high rainfall tract of northern agro-climatic zone of Kerala. J. Spices Arom. Crops 17: 16"20.

Kendall M G 1975 "Rank Correlation Methods", Charles Griffin, London, UK.

Krishnakumar K N \& Rao G S L H V P 2006 Climatological droughts in the tropical monsoon climate of Kerala, India. J. Agrometeorol. 8: 248-253.

Krishnakumar K N \& Rao G S L H V P 2008 Trends and variability in northeast monsoon rainfall over Kerala. J. Agrometeorol. 10: 123-126.

Krishnakumar K N \& Rao G S L H V P \& Gopakumar C S 2009 Rainfall trends in twentieth century over Kerala, India. Atmospheric Envt. 43: 1940-1944.

Mallappa J M, Kanannavar P S \& Ravindra Y 2015 Impact of climate change on precipitation for the upper Cauvery river basin, Karnataka state. Int. J. Agri. Sci. Res. 5: 99104.

Manivannan S, Khola O P S \& Dinesh D 2016 Probability analysis of weekly rainfall for crop planning in Nilgiris hills of Tamil Nadu. J. Agrometeorol. 18: 163-164. 
Mann H B 1945 Nonparametric tests against trend. Econometrica 13: 245-259.

Manorama K, Ravichandran G \& Joseph T A 2007 Rainfall analysis and crop planning for the Nilgiris. J. Agrometeorol. 9: 209-215.

Murugan M, Shetty P K, Ravi R \& Anandhi A 2011 Climate change and crop yields in the Indian Cardamom Hills, 1978-2007 CE. Clim. Chang. 1573-1480. DOI10.1007/s10584-0110115-8.

Murugan M, Shetty P K, Anandhi A, Ravi R, Alappan S, Vasudevan M \& Sreeja G 2009 Rainfall changes over tropical montane cloud forests ofsouthern Western Ghats, India. Curr. Sci. 97: 1755-1760.

Murugan M, Miniraj N \& Joseph C R 2000 Changes in climatic elements and their impact on production of cardamom (Elettaria cardamomum M.) in the cardamom hills of Kerala, India. J. Spices Arom. Crops 9: 157160.

Rao G S L H V P \& Krishnakumar K N 2005 Monsson onset over Kerala (India). J. Agrometeorol. 7: 161-167.

Raju B M K, Rao K V, Venkateswarlu B, Rao A V M S, Rao, C A R, Rao V U M, Rao B B, Kumar N
R, Dhakar R, Swapna N \& Latha P 2013 Revisiting climatic classification in India: a district level analysis. Curr. Sci. 105: 492495.

Sen P K 1968a On a class of aligned rank order tests in two-way layouts. Ann. Math. Stat. 39: 1115-1124.

Sen P K 1968b Estimates of the regression coefficient based on Kendall's tau. J. Am. Stat. Assoc. 39: 1379-1389.

Sushant S K, Balasubramani \& Kumaraswamy K 2015 Spatio-temporal Analysis of Rainfall Distribution and Variability in the Twentieth Century, Over the Cauvery Basin, South India (pp.21-41). In: Ramkumar, Muthuvairavasamy, Kumaraswamy K \& Mohanraj R (Eds.), Environmental management of river basin ecosystems. Springer International Publishing Switzerland, Springer Earth System Sciences, DOI 10.1007/978-3-31913425-3_2.

WGEEP 2011 Report of the Western Ghats Ecology Expert Panel, The Ministry of Environment and Forests, Government of India, New Delhi available at http://www.moef.nic.in/ downloads/public-information/wg23052012.pdf (accessed on 25-8-2016). 


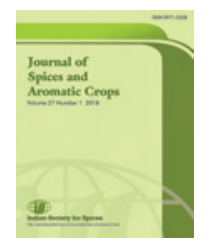

Effect of biofertilizers and organic supplements on the growth of black pepper rooted cuttings (Piper nigrum L.)

T S Aswathy*, M K Dhanya, J Jintu, T Sathyan, T T Preethy \& M Murugan

Cardamom Research Station, Kerala Agricultural University,

Pampadumpara-685 553, Idukki, Kerala.

*E-mail:aswathyrethna91@gmail.com

Received 06 November 2017; Revised 06 February 2018; Accepted 26 March 2018

\begin{abstract}
An experiment was conducted at the Cardamom Research Station, Kerala Agricultural University, Pampadumpara (Kerala) with an objective to study the effect of different biofertilizers (Phosphorus solubilizing bacteria, Azospirillum and Plant Growth Promoting Rhizobacteria Mix I) and organic supplements (fish extract and humic acid) on the growth of black pepper rooted cuttings. The results of the experiment indicated that application of Phosphorus solubilizing bacteria $(5 \mathrm{~g})$ along with Azospirillum (5 g), humic acid (0.2\%) and fish extract $(0.5 \%)$ was the best combination for the production of black pepper rooted cuttings with improved vegetative characters (plant height, number of leaves, number of roots, length of roots and leaf area) compared to theirindividual inoculation. This innovative information can be effectively utilized and advocated for the commercial production of black pepper rooted cuttings with lusty growth.
\end{abstract}

Keywords: black pepper, bio fertilizers, organic supplements, roots and shoot growth, nutrient management

The availability of quality planting material is one of the major issues that black pepper growers face in India. The conventional propagation methods have several limitations due to low success rate, poor rooting, spread of soil borne pathogens and poor survival rate of transplanted rooted cuttings (Rini et al. 2016). In order to overcome these problems, a technological intervention is needed to boost both the production and supply of quality planting materials. In the context of promoting organic cultivation, the use of biofertilizers for quality seedlings/cuttings production secures much importance because they are eco-friendly, low cost, capable of improving crop yields and quality sustainably. Biofertilizers improve growth rate of plants and soil health as they act as plant strengthners, phytostimulators, plant health improvers, and have the potential to fix nitrogen (Babalola 2014). The fertility of the soil is also restored by biofertilizers so that plants were better protected from getting any diseases (Amna 2010). Fish emulsions are used as a source of nitrogen during the early or vegetative stage of development to boost plant growth and also this has been documented to promote seedling growth in many crops (Murray \& Anderson 2004). Humic substances 
are organic materials thatimprove soil structure, fertility and nutrient uptake (Trevisan et al. 2010). Hence, the present study was designed and conducted at the Cardamom Research Station, Pampadumpara, Kerala Agricultural University during 2017 to evaluate the efficacy of promising bio-fertilizers and select organic supplements on the production of quality black pepperrooted cuttings.

The most popular local black pepper variety 'Karimunda'was chosen in the evaluation. This study comprised eight treatments including untreated control, sole and combined application of following bioagents and organic supplements.

Treatments with dose

$\mathrm{T}_{1} \quad$ Phosphorus solubilizing bacteria(PSB) @10 $\mathrm{g} \mathrm{plant}^{-1}$

$\mathrm{T}_{2} \quad$ Azospirillum @10 g plant ${ }^{-1}$

$\mathrm{T}_{3} \quad$ Plant Growth Promoting Rhizobacteria (PGPR Mix I) @10 g plant ${ }^{-1}$

$\mathrm{T}_{4} \quad 0.2 \%$ Humic acid @100 ml plant ${ }^{-1}$

$\mathrm{T}_{5} \quad 0.5 \%$ Fish extract $@ 100 \mathrm{ml} \mathrm{plant}^{-1}$

$\mathrm{T}_{6} \quad$ PSB $@ 5 \mathrm{~g} \mathrm{plant}^{-1}+$ Azospirillum $@ 5 \mathrm{~g} \mathrm{plant}^{-1}$ $+0.2 \%$ Humic acid @100 ml plant $\mathrm{m}^{-1}+0.5 \%$ Fish extract @100 ml plant ${ }^{-1}$

$\mathrm{T}_{7} \quad$ PGPR Mix I @5 g plant ${ }^{-1}+0.2 \%$ Humic acid @100 ml plant m $^{-1}+0.5 \%$ Fish extract @100 ml plant ${ }^{-1}$

$\mathrm{T}_{8} \quad$ Untreated control

Local Karimunda cuttings were planted in polythene bags size of $20 \times 15 \mathrm{~cm}$ filled with potting mixture composed of garden soil, sand, and farm yard manure in 1:1:1 proportion. The potting mixture had an initial nutrient status of organic carbon $(1.98 \%), \mathrm{N}(0.704 \mathrm{mg} / 100 \mathrm{~g})$ available $\mathrm{P}(4.01 \mathrm{mg} / 100 \mathrm{~g})$ and $\mathrm{K}(43 \mathrm{mg} / 100$ g) with a $\mathrm{pH}$ of 5.3. The treatments were superimposed and evaluated in vivo under greenhouse condition. Commercial formulations of phosphorus solubilizers $\left(5 \times 10^{7}\right.$ cfu), Azospirillum (5x10 $\mathrm{cfu})$ and PGPR Mix I (Consortium of Azospirillum lipoferum, Azotobacter chroococcum, Bacillus megaterium and Bacillus sporothermodurans each with $5 \times 10^{7} \mathrm{cfu}$ ) were obtained from the Department of Agricultural Microbiology, College of Agriculture, Vellayani. The humic acid containing $12 \%$ potassium humate was used in this study. Fish extract was prepared as per the standard procedure. Equal quantity of fish and jaggery was taken, sliced, mixed and kept in closed container with periodical stirring up to 30 days, after that the solution was strained through a muslin cloth and stored.

The experiment was conducted using Completely Randomized Design (CRD) with four replications. Five plants were kept in each replication.In addition to this fiveplants/ treatment were also maintained for destructive sampling to study the root characters. Talc based formulation of PSB, Azospirillum, PGPR Mix I, humic acid and fish extract individually and in combination were applied to the root zone of one month old black pepper cuttings grown in polythene bags. The treatments were given twice at fortnightly interval (when the plants were 30 and 45 days old).

Observations on the height, number of leaves, leaf area and root characters were recorded 60 days after second treatment application. The experimental soil (potting media) was analyzed for physicochemical properties like $\mathrm{pH}$, organic carbon and available N, P and K content. The leaf chlorophyll content was estimated as per the protocol of Sadasivam \& Manickam (1992). The data collected from the experimentwere processed statistically with appropriate statistical tool for the interpretation of the results.

There was no significant difference with respect to morphological characters before treatment application. Butgood improvement invegetative characterswas noted after the application of biofertilizers and organic supplements.Black pepper rooted cuttings responded well to combined inoculation of 
biofertilizers and organic supplements compared to individual inoculation and control (Table 1). Application of PSB along with Azospirillum, humic acid and fish extract $\left(\mathrm{T}_{6}\right)$ resulted increased plant height $(98.66 \mathrm{~cm})$, numbers of leaves (12.16), number of roots (13.50), root length $(28 \mathrm{~cm})$ and highest leaf area $\left(63.18 \mathrm{~cm}^{2}\right) 60$ days after second treatment application compared to all the other treatments. Similar increaseof growth was recorded in black pepper for combined inoculation of biofertilizers such as Azospirillum, Phosphobacteria and VAM (Kandiannan et al. 2000; Bopaiah \& Khader 1989). In addition to this, fish emulsions have been reported to increase the nitrogen accessibility (Weinert et al. 2014). According to Chen \& Aviad (1990) the application of humic substances increase root length and produce more secondary roots. As a result, the plants were capable of absorbing more available nutrients from the soil which in turn resulted better establishment and subsequent growth and development. Thus, the combined inoculation of PSB and Azospirillum along with humic acid and fish extractperformed best through improving the morphological characters of the cuttings compared to their individual application.

Total chlorophyll content was maximum in plants treated with PSB along with Azospirillum, humic acid and fish extract $(0.64 \mathrm{mg} / 100 \mathrm{~g})$ followed by the combined application of PGPR Mix I along with Azospirillum, humic acid and fish extract $(0.60 \mathrm{mg} / 100 \mathrm{~g})$. The least quantity of chlorophyll was observed in control plants $(0.42 \mathrm{mg} / 100 \mathrm{~g})$. This can be attributed to the increased uptake of nutrients leading to enhanced chlorophyll content. Pereira et al. (2015) reported that maize plants when inoculated with Azospirillum under different dosages of nitrogen enhanced the chlorophyll content. Our best treatment also includes Azospirillum as one component. This contributes to the increased chlorophyll content of the treated plants.

Nutrient status of the potting mixture 60 days after second treatment application (Table 2) showed that, readily available nutrient content of potting mixture was improved through the application of biofertilizers and organic supplements compared to control. Among the treatments, PSB along with Azospirillum humic acid and fish extracttreated soil showed higher levels of organic carbon $(3.17 \%)$, available phosphorus (17.83 mg/100 g) and potassium (84.66 mg/100 g) whereas, available nitrogen was highest for combined application of PGPR Mix I along with Azospirillum, humic acid and fish extract (1.05 mg/100 g). Increased availability of nutrients in the potting mixture was attributed through combined application of biofertilizers and organics. Bio inoculants have had influence in increasing the organic carbon content of turmeric (Sumathi et al. 2011). Biofertilizers like Azospirillum and PSB were highly beneficial to plants through augmentation of nitrogen and phosphorus content in soil, thus making these two essential nutrients available to the plant and also produce phytohormones like auxins (Singh et al. 2011; Rocheli et al. 2015). In our experiment also treatments consisting of PSB along with Azospirillum, humic acid and fish extract $\left(\mathrm{T}_{6}\right)$ resulted in high available organic carbon, P \& $\mathrm{K}$ compared to control which is responsible for increased growth parameters observed. The increase in P availability could be attributed to the application of PSB which produces organic acids that act as a chelating agent and thereby, releases $\mathrm{P}$ into the soil solution and making it more available resulted in improved root growth. These findings are in agreement with the findings of Naik \& Hari babu (2007) and Sharma et al. (2009) in guava.

It is evident that, the combined application of PSB (5 g) along with Azospirillum (5 g), 0.2\% humic acid $\left(100 \mathrm{~mL} \mathrm{plant}^{-1}\right)$ and $0.5 \%$ fish extract (100 mL plant $\left.{ }^{-1}\right)$ followed by PGPR Mix I (5 g) along with $0.2 \%$ humic acid $\left(100 \mathrm{~mL}^{2}\right.$ plant $\left.{ }^{-1}\right)$ and $0.5 \%$ fish extract $\left(100 \mathrm{~mL} \mathrm{plant}^{-1}\right)$ produced healthy black pepper rooted cuttings with good morphological characters than those of sole application of any of these biofertilizers and organics. Therefore, this technology could be effectively advocated to produce black pepper root cuttings with lusty growth in nurseries. 
Nutrition for black pepper cuttings

Table 1. Effect of biofertilizers and organic supplements on growth of black pepper rooted cuttings after second treatment application

\begin{tabular}{|c|c|c|c|c|c|}
\hline \multirow[t]{2}{*}{ Treatments } & \multicolumn{5}{|c|}{$60 \mathrm{DAT}$} \\
\hline & $\begin{array}{l}\text { Plant } \\
\text { height } \\
(\mathrm{cm})\end{array}$ & $\begin{array}{l}\text { Number } \\
\text { of } \\
\text { leaves }\end{array}$ & $\begin{array}{l}\text { Number } \\
\text { of } \\
\text { roots }\end{array}$ & $\begin{array}{l}\text { Length } \\
\text { of } \\
\text { roots }\end{array}$ & $\begin{array}{l}\text { Leaf } \\
\text { area } \\
(\mathrm{cm})\end{array}$ \\
\hline Phosphorus solubilizing bacteria (PSB)- $10 \mathrm{~g}$ plant $^{-1}$ & 76.50 & 10.33 & 12.83 & 21.00 & 48.45 \\
\hline Azospirillum- $10 \mathrm{~g}_{\text {plant }}{ }^{-1}$ & 75.50 & 9.00 & 9.16 & 15.86 & 43.29 \\
\hline PGPR Mix I- 10 g plant $^{-1}$ & 73.83 & 10.00 & 9.83 & 17.16 & 46.02 \\
\hline Humic acid@2\% & 67.33 & 8.50 & 9.20 & 15.46 & 45.60 \\
\hline Fish amino acid @0.5\% & 70.66 & 8.83 & 6.26 & 11.83 & 36.98 \\
\hline $\begin{array}{l}\text { Phosphorus solubilizing bacteria (PSB) } 5 \mathrm{~g} \mathrm{plant}^{-1}+ \\
\text { Azospirillum } 5 \mathrm{~g} \text { plant }{ }^{-1}+\text { Humic acid @2\% + } \\
\text { Fish amino acid @0.5\% }\end{array}$ & 98.66 & 12.16 & 13.50 & 28.00 & 63.18 \\
\hline $\begin{array}{l}\text { PGPR Mix I } 5 \mathrm{~g} \mathrm{plant}^{-1}+\text { Humic acid @ } 2 \% \text { + } \\
\text { Fish amino acid @ } 0.5 \%\end{array}$ & 79.50 & 10.66 & 10.16 & 36.00 & 48.91 \\
\hline Control & 49.33 & 6.50 & 5.13 & 6.33 & 23.52 \\
\hline $\mathrm{CD}(\mathrm{P}<0.05)$ & 18.779 & 2.418 & 0.491 & 1.805 & 0.243 \\
\hline $\mathrm{CV}$ & 14.352 & 14.409 & 3.027 & 5.425 & 0.320 \\
\hline
\end{tabular}

Table 3. Effect of biofertilizers and organic supplements on nutrient status of potting mixture 60 days after second treatment application

\begin{tabular}{|c|c|c|c|c|c|}
\hline Treatments & $\mathrm{pH}$ & $\begin{array}{l}\text { Organic } \\
\text { carbon } \\
\quad \%\end{array}$ & $\begin{array}{l}\text { Available } \\
\quad \mathrm{N} \\
(\mathrm{mg} / 100 \mathrm{~g})\end{array}$ & $\begin{array}{l}\text { Available } \\
\text { P } \\
(\mathrm{mg} / 100 \mathrm{~g})\end{array}$ & $\begin{array}{l}\text { Available } \\
\text { K } \\
(\mathrm{mg} / 100 \mathrm{~g})\end{array}$ \\
\hline Phosphorus solubilizing bacteria (PSB)- $10 \mathrm{~g}$ plant $^{-1}$ & 6.7 & 2.64 & 0.906 & 11.41 & 73.16 \\
\hline Azospirillum- $10 \mathrm{~g}_{\text {plant }}{ }^{-1}$ & 6.5 & 2.63 & 0.900 & 13.63 & 74.83 \\
\hline PGPR Mix I- 10 g plant $^{-1}$ & 7.1 & 2.65 & 0.913 & 14.29 & 75.83 \\
\hline Humic acid @2\% & 6.3 & 2.63 & 0.903 & 11.35 & 68.83 \\
\hline Fish amino acid @0.5\% & 6.8 & 2.64 & 0.903 & 7.02 & 66.83 \\
\hline $\begin{array}{l}\text { Phosphorus solubilizing bacteria (PSB) } 5 \mathrm{~g} \mathrm{plant}^{-1}+ \\
\text { Azospirillum } 5 \mathrm{~g} \text { plant } \mathrm{t}^{-1}+\text { Humic acid @ } 2 \%+ \\
\text { Fish amino acid @0.5\% }\end{array}$ & 7.38 & 3.17 & 0.970 & 17.83 & 84.66 \\
\hline $\begin{array}{l}\text { PGPR Mix I } 5 \text { g plant }^{-1}+\text { Humic acid } @ 2 \%+ \\
\text { Fish amino acid @ } 0.5 \%\end{array}$ & 7.25 & 2.92 & 1.053 & 14.75 & 80.33 \\
\hline Control & 5.5 & 2.01 & 0.706 & 3.56 & 46.00 \\
\hline $\mathrm{CD}(\mathrm{P}<0.05)$ & 0.444 & 0.061 & 0.024 & 0.206 & 5.356 \\
\hline $\mathrm{CV}$ & 3.915 & 1.411 & 1.550 & 0.275 & 4.336 \\
\hline
\end{tabular}




\section{References}

Amna A 2010 Biofertilizers: Types Benefits and Applications. Biotech articles. Available as:https://www.biotecharticles.com/ Agriculture-Article/Biofertilizers-TypesBenefits-and-Applications-172.

Babalola O O 2014 Does nature make provision for backups in the modification of bacterial community structures?. Biotechnol. Genet. Engg. Rev. 30: 31-48.

Bopaiah B M \& Khader K B 1989 Effect of solarized potting mixture on growth of black pepper (Piper nigrum L.). Indian J. Agri. Sci. 59: 682683.

Chen Yonah \& Aviad Tsila 1990 Effects of humic substances on plant growth. In: Maccarthy Patrick, Bloom P R, Clapp C E \& Malcolm R L (Eds.), Humic substances in soil and crop sciences-Selected readings, Madison, Wis. Am. Soc. Agron. 161-186.

Kandiannan K, Sivaraman K, Anandaraj \& Krishnamurthy K S 2000 Growth and nutrient content of black pepper (Piper nigrum L.) cuttings as influenced by inoculation with biofertilizers. J. Spices Arom. Crops 9: 145-147.

Murray R \& Anderson R G 2004 Organic fertilizers and composts for vegetable transplant production. University of Kentucky, Greenhouse use of organic fertilizers and composts -3 Floriculture Research Report $17-04$.

Naik M H \& Haribabu R 2007 Feasibility of organic farming in guava (Psidium guajava L.). Acta Hort. 735: 365-372.

Pereira L M, Pereira E M, Revolti L T M, Zingaretti S M \& Moro G V 2015 Seed quality, chlorophyll content index and leaf nitrogen levels in maize inoculated with Azospirillum brasilense. Revista Ciencia Agronomica. 46: 630-637.
Rini C R, Neema V P \& Ramya J 2016 Evaluation of biocontrol agents and fermented organic preparations on growth of rooted cuttings in black pepper nursery. In: Malhotra S K, Kandiannan K, Mini Raj K, Neema V P, Prasath D, Srinivasan V, Homey Cheriyan \& Femina (Eds.) (pp.106-110). ProceedingsNational seminar on Planting material production in spices. Directorate of Arecanut and Spices Development, Kozhikode, Kerala, 331p.

Rocheli S, Ambrosini A, Luciane M P \& Passaglia 2015 Plant growth-promoting bacteria as inoculants in agricultural soils. Genet. Mol. Biol. 48: 1678-4685.

Sadasivam S \& Manickam A 1992Biochemical Methods for Agricultural Sciences. Wiley Eastern Ltd. New Delhi. 242p.

Singh J S, Pandey V C \& Singh D P 2011 Efficient soil microorganisms: a new dimension for sustainable agriculture and environmental development. Agri. Ecosyst. Environ. 140: 339-353.

Sharma A, Kher R, Wali V K \& Bakshi P 2009 Effect of biofertilizers and organic manures on physico-chemical characteristics and soil nutrient composition of guava (Psidium guajava L.) cv. Sardar. J. Res. 8: 150-156.

Sumathi C S, Ramesh N, Balasubramanian V \& Kannan R V 2011 Microbial bio-inoculant potential on turmeric (Curcuma Longa L.) growth improvement under tropical nursery conditions. Asian J. Exp. Biol. Sci. 2: 612-623.

Trevisan S, Francioso O, Quaggiotti S, Nardi S 2010 Humic substances biological activity at the plant-soil interface: From environmental aspects to molecular factors. Plant Signal Behav. 5: 635-643.

Weinert E, Miller S A, Ikeda, D M, Chang, K C S, Joseph M, Mc-Ginn, J M \& DuPonte M W 2014 Natural Farming, Fish Amino Acid. Manoa, Hawaii, College of Tropical Agriculture and Human resources, 3p. 


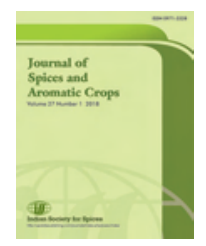

\title{
Effect of biocontrol agents on production of rooted back pepper cutting by serpentine method
}

\author{
R S Bhai*, K P Subila, S J Eapen, A Reshma, R Pervez ${ }^{1}$, A Ishwara Bhat \& V Srinivasan
}

ICAR-Indian Institute of Spices Research, Marikkunnu PO, Kozhikode-673 012, Kerala.

${ }^{*}$ E-mail: rsbhai@rediffmail.com

Received 20 December 2017; Revised 20 March 2018; Accepted 03 April 2018

\begin{abstract}
Availability of disease free quality planting material is a major limiting factor in black pepper cultivation. In order to meet the increasing demand and also to create awareness on good agricultural practices for healthy disease free planting material production to farmers, a nursery experiment was started with improved varieties of black pepper by adopting a non-chemical biointensive management strategy. Here solarization of potting mixture was the main concern followed my amending the solarized potting mixture with potential bioagents. The experiment was designed in a two factor CRD with four improved varieties and five treatments. Each treatment contains a combination of two bioagents with antifungal and nematicidal properties respectively. The common recommended fungicide Metalaxyl-Mancozeb $(0.125 \%)$ and nematicide carbsosulfan $(0.1 \%)$ was used as control. The treatments were incorporated individually into solarized potting mixture and planted with improved varieties used viz., IISR Girimunda, IISR Malabar Excel, IISR Shakti and IISR Thevam, The plants in each treatment were kept for multiplication by serpentine method with proper irrigation and phytosanitation. The results of plant growth and establishment in different treatments, showed that fortification of solarized potting mixture with Trichoderma harzianum + Pochonia chlamydosporia combination or combination of Streptomyces strains (Act 2+9) are significantly superior (35.46\% and 21\% respectively) for the production of healthy rooted planting material. IISR Malabar Excel and IISR Thevam produced the maximum number of plants from a single node cutting in treatment with $T$. harzianum $+P$. chlamydosporia (T1) (59 nos. and 51 nos. respectively) followed by IISR Malabar Excel with Act 2+9 and Act 5+9 (45 nos. each). So an average of 6-7 plants/month/cutting was produced in the potential treatment while it was only 3-4 plants in control. The advantage of the method is that, after solarization and fortification with respective bioagents, there is no need for further application of any fungicides, insecticides or any other nutrient spray as usually done. Thus the method of soil solarization followed by fortification of either with T. harzianum $+P$. chlamydosporia or combination of Streptomyces strains viz., Ketasatospora setae (Act 2) and S. tauricus (Act9) is found suitable for the production of healthy quality planting material of high yielding varieties to meet the increasing demand of planting material with a C:B ratio of 1:2.
\end{abstract}


The demand for healthy planting material of high yielding black pepper varieties is on the increase and the country needs large quantity of quality planting material to meet the increasing demand. The present study was aimed to establish a model nursery to produce disease free healthy planting material of improved varieties of black pepper by creating awareness among farmers with good agricultural practices and by adopting nonchemical bio-intensive management strategies.

The experiment was conducted in collaboration with a farmer at Omasserry in Thamarassery Panchayat (Kozhikode district). Initially a nursery shed was constructed $(24 \mathrm{~m} \times 20 \mathrm{~m})$ and roofed with white polythene sheet of 100 microns. Single node rooted plants of four released varieties of black pepper viz., IISR Girimunda, IISR Malabar Excel, IISR Shakti and IISR Thevam (indexed for viruses and raised under insect proof conditions at ICAR-Indian Institute of Spices Research, Chelavoor) was used as the source material.

Nursery mixture was prepared by mixing soil, sand and FYM in 1:2:1 and sterilized by solarization. Briefly, the nursery mixture prepared was made into small beds of size $3 \times 1 \mathrm{~m}$ in a place where there is direct exposure to sunlight. The bed was watered thoroughly and covered with polythene sheet of 100 microns and sealed air tight and kept for solarization on $5^{\text {th }}$ November till $25^{\text {th }}$ December 2015.

Biocontrol agents such as Trichoderma harzianum, Pochonia chlamydosporia, and 3 promising Streptomyces sp. viz., Streptomyces tauricus (strain Act 9). Streptomyces sp. (strain Act 5) and Ketosatospora setae (strain Act 2) (Bhai et al. 2016) in different combinations were used as growth promoters as well as bioagents for incorporating into the nursery mixture.

The experiment was designed in a two factor CRD with four improved varieties of IISR and five treatments. The five treatments were T1T. harzianum + P. chlamydosporia, T2- Streptomyces strains 2+9, T3- Streptomyces strains 5+9, T4Metalaxyl-Mz+ Carbsosulfan and T5-control without any amendments. The individual treatments were incorporated with the solarized nursery mixture separately and filled in polythene bags $(15 \mathrm{~cm} \times 10 \mathrm{~cm}) @ 250 \mathrm{~g} \mathrm{bag}^{-1} . \mathrm{T}$. harzianum and $P$. chlamydosporia were made in liquid form with water and added @100 mL (cfu $10^{9} \mathrm{~mL}^{-1}$ ) each to $100 \mathrm{~kg}$ potting mixture. Streptomyces spp. grown as broth culture in Nutrient broth and $100 \mathrm{~mL}$ (cfu $10^{10} \mathrm{~mL}^{-1}$ ) mixed with $1 \mathrm{~kg}$ vermicompost and grown for 5 days (cfu10 $\left.\mathrm{mL}^{-1}\right)$ ) and applied @1 kg $100 \mathrm{~kg}^{-1}$ potting mixture. The treatment imposed poly bags were arranged inside the nursery and planted with single node virus free (indexed) rooted cuttings as mentioned above and were allowed to grow by serpentine method.

When the number of rooted nodes in the serpentine reached around 10, the rooted middle cuttings were cut and separated leaving three plants at the tip and nucleus plant at the end and were kept for establishment to a 3-4 leaf stage in the same nursery. Five plants each were taken from each treatment and observed for biometric growth parameters. The biometric observations were recorded on height of the plant, fresh and dry weight of the plant, number of roots, root length and root biomass. The soil was analysed for the presence of targeted pathogens like Phytophthora capsici and nematodes (Radopholus similis and Meloidogyne incognita), $\mathrm{pH}$ and dehydrogenase activity (DHA).

The data were analyzed by using PROC ANOVA procedure of SAS 9.3. Least square means statements were used for mean separation.

After nine months of growth by serpentine method, the variety IISR Malabar Excel and IISR Thevam produced the maximum number of plants in T1 (T. harzianum + P. chlamydosporia (59 nos. and 51 nos. respectively) followed by T2 (Act 2+9) in case of Malabar Excel (45nos) and T3 (Act 5+9) (45 nos) in case of Thevam, from a single node cutting. An average of 6-7 plants/month/cutting was produced from these varieties with the treatment $\mathrm{T} 1$, while it was only 4 plants/month/ cutting in control. In case of IISR Girimunda, the performance was almost 
the same with all the three bioagent combinations when compared to Metalaxyl-Mz + Carbsosulfan and control. However, IISR Shakti showed comparatively lesser performance with bioagent combinations. The results of the study clearly showed the response of varieties to bioagents. In all cases, the number of plants produced with Metalaxyl-Mz + Carbsosulfan (T4) was comparatively lesser when compared to control (Table 1). The root system was also healthy in all treatments except for control where the root was not profusely grown. No disease of any kind was observed in any of the plants. Though there is no difference between varieties in fresh weight of the plant, the dry weight (Fig. 1) is significantly superior in treatment with Streptomyces strains (Act 2+9) and is at par with T. harzianum and $P$. chlamydosporia. Not much difference was observed in the number of leaves between treatments but, there is difference in the height of the plants (Fig. 2) where bioconsortia showed increased height when compared to Metalaxyl-Mz. + Carbsosulfan and control. Difference was observed in number of roots, root length, and root fresh and dry biomass (Tables 2 to 5). Since the nursery mixture was solarised and irrigation was limited to once in two days, there was no incidence of soil borne infections caused by Phytophthora capsici,
Sclerotium rolfsii or nematodes (the common diseases otherwise observed in nurseries), in any of the treatments including control (Table $6)$. The $\mathrm{pH}$ of the soil in untreated plants ranged from 4.55-5.66. It is interesting to note that the $\mathrm{pH}$ of the soil is raised to neutral in treatments with $T$. harzianum $+P$. chlamydosporia where it ranged from 6.86-7.63. In the case of Streptomyces combinations the $\mathrm{pH}$ ranged from 4.85 to 6.85 (Table 6) and the dehydrogenase activity which reflects the total oxidative activity of soil microflora, (Liang et al. 2014) was unaffected by the incorporation of bioagents like Trichoderma, Pochonia or Streptomyces sp. (Table 6). So without the addition of external nutrients, the micro flora enriched solarized mixture supported the growth of plants as well as prevented the incidence of infection caused by nematodes, Phytophthora or any other soil borne pathogens of black pepper. This may be due to the increased microbial activity either through the production of IAA or other growth promoting traits including siderophore production which is observed in the case Streptomyces strains (Suseela Bhai et al. 2016).

Thankamani et al. (2005) reported the effect of Pseudomonas fluorescens (IISR-6) and $T$. harzianum (P-26) on the growth of black pepper rooted cuttings in the nursery. However, no

Table 1. No. of cuttings produced in nine months from a single plants

\begin{tabular}{|c|c|c|c|c|c|c|}
\hline Treatments & $\begin{array}{c}\text { IISR } \\
\text { Girimunda }\end{array}$ & $\begin{array}{c}\text { IISR } \\
\text { Malabar } \\
\text { Excel }\end{array}$ & $\begin{array}{c}\text { IISR } \\
\text { Shakthi }\end{array}$ & $\begin{array}{c}\text { IISR } \\
\text { Thevam }\end{array}$ & $\begin{array}{l}\text { Sub } \\
\text { plot } \\
\text { mean }\end{array}$ & $\begin{array}{c}\text { Increase } \\
\text { over } \\
\text { control (\%) }\end{array}$ \\
\hline $\begin{array}{l}\mathrm{T}_{1}-\mathrm{T} \text {. harzianum }+ \\
\text { P. chlamydosporia }\end{array}$ & 36.00 & 59.60 & 23.00 & 51.00 & 42.40 & 35.46 \\
\hline $\mathrm{T}_{2}$-Act $2+9$ & 36.00 & 45.60 & 32.00 & 38.00 & 37.90 & 21.08 \\
\hline $\mathrm{T}_{3}$-Act $5+9$ & 34.00 & 34.00 & 32.60 & 45.80 & 36.60 & 15.00 \\
\hline $\begin{array}{l}\mathrm{T}_{4}-\text { Metalaxyl-Ma } \\
\text { Carbsosulfan }\end{array}$ & 25.40 & 26.40 & 34.00 & 32.60 & 29.60 & -5.43 \\
\hline $\mathrm{T}_{5}$-Control & 23.60 & 29.40 & 41.60 & 30.60 & 31.30 & - \\
\hline Main plot mean & 31.00 & 39.00 & 32.64 & 39.60 & & \\
\hline \multicolumn{7}{|l|}{ LSD $(\mathrm{P}<0.05)$} \\
\hline VT & 0.87 & & & & & \\
\hline $\mathrm{T}$ & 0.95 & & & & & \\
\hline $\mathrm{V} \times \mathrm{T}$ & 1.90 & & & & & \\
\hline
\end{tabular}




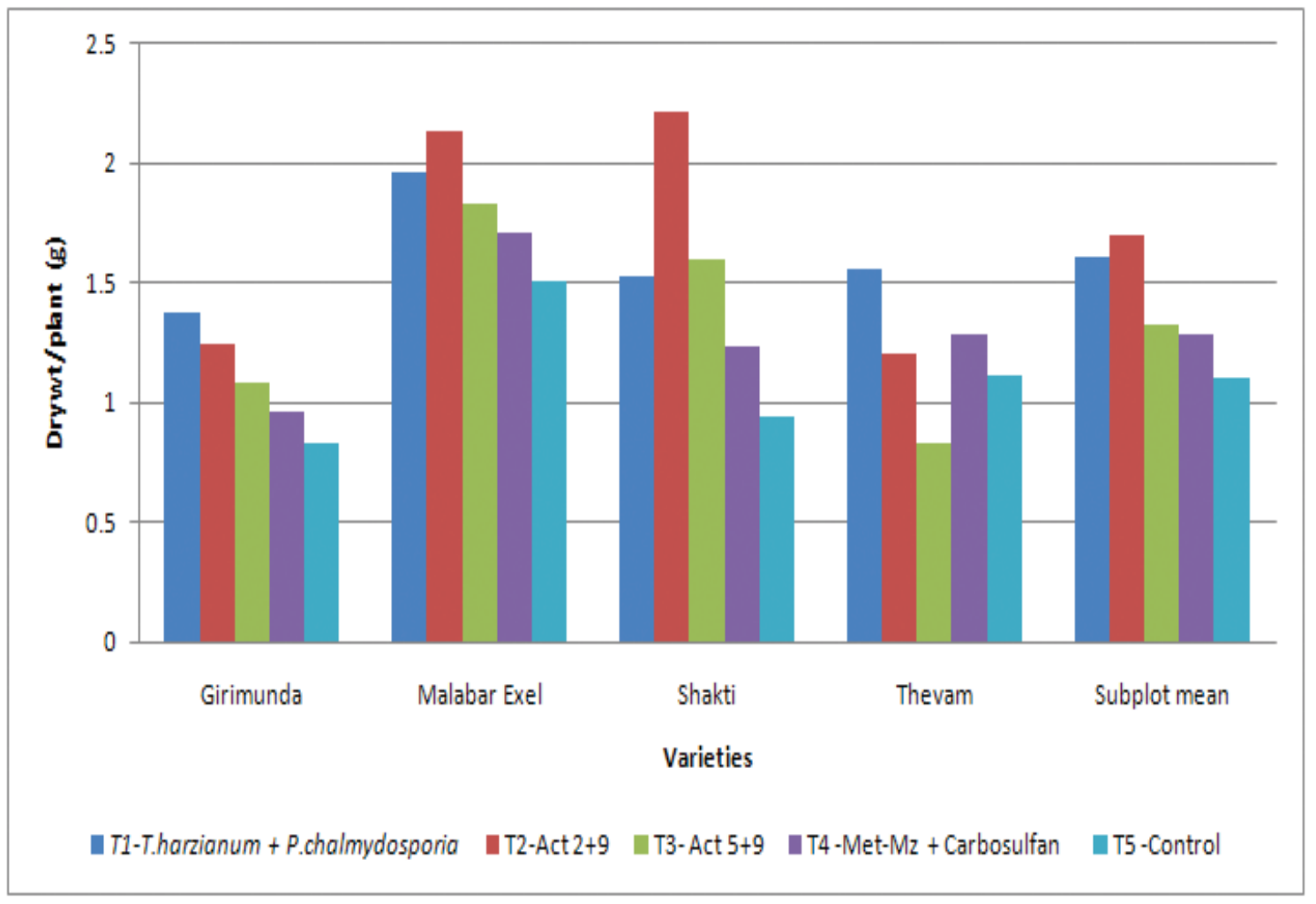

Fig. 1. Dry wt (g)/plant

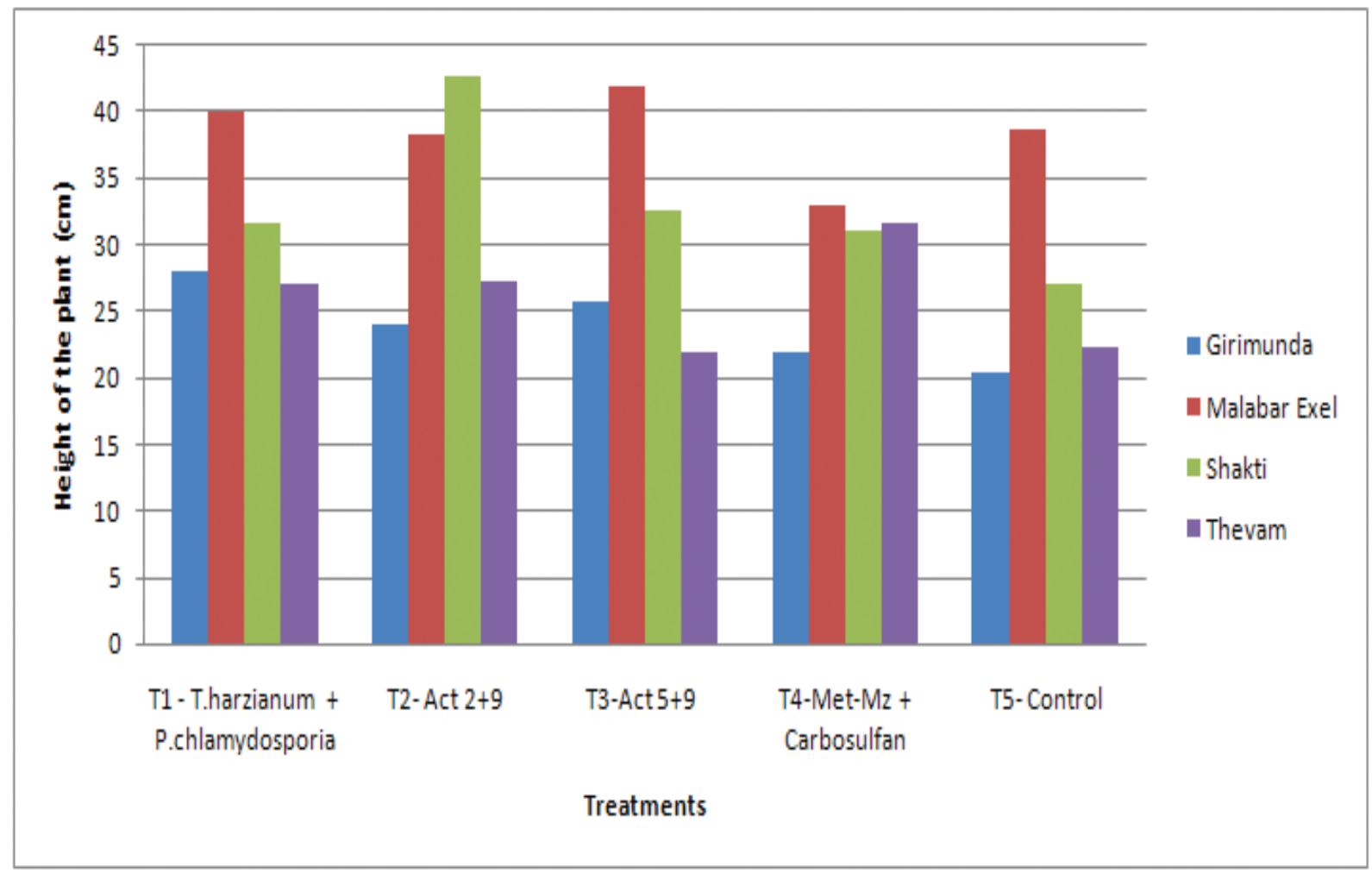

Fig. 2. Height of the plants 
Bio-control agents for black pepper cuttings production

Table 2. Influence of treatments on number of roots

\begin{tabular}{|c|c|c|c|c|c|}
\hline Treatments & $\begin{array}{c}\text { IISR } \\
\text { Girimunda }\end{array}$ & $\begin{array}{c}\text { IISR } \\
\text { Malabar } \\
\text { Excel }\end{array}$ & $\begin{array}{c}\text { IISR } \\
\text { Shakthi }\end{array}$ & $\begin{array}{c}\text { IISR } \\
\text { Thevam }\end{array}$ & $\begin{array}{c}\text { Sub } \\
\text { plot mean }\end{array}$ \\
\hline $\mathrm{T} 1-T$. harzianum $+P$. chlamydosporia & 7.67 & 8.67 & 4.00 & 12.67 & 8.25 \\
\hline T2-Act $2+9$ & 6.00 & 11.33 & 8.33 & 10.00 & 8.92 \\
\hline T3-Act 5+9 & 6.67 & 8.00 & 9.33 & 8.33 & 8.08 \\
\hline T4-Metalaxyl-Mancozeb + Carbsosulfan & n 6.33 & 7.33 & 5.00 & 8.00 & 6.67 \\
\hline T5-Control & 8.67 & 6.33 & 5.33 & 7.33 & 6.92 \\
\hline Main plot mean & 7.07 & 8.33 & 6.4 & 9.27 & \\
\hline \multicolumn{6}{|l|}{ LSD $(P<0.05)$} \\
\hline V & 2.02 & & & & \\
\hline $\mathrm{T}$ & NS & & & & \\
\hline $\mathrm{V} \times \mathrm{T}$ & NS & & & & \\
\hline
\end{tabular}

Table 3. Influence of treatments on root dry biomass (g)

\begin{tabular}{lccccc}
\hline Treatments & $\begin{array}{c}\text { IISR } \\
\text { Girimunda }\end{array}$ & $\begin{array}{c}\text { IISR } \\
\text { Malabar } \\
\text { Excel }\end{array}$ & $\begin{array}{c}\text { IISR } \\
\text { Shakthi }\end{array}$ & $\begin{array}{c}\text { IISR } \\
\text { Thevam }\end{array}$ & $\begin{array}{c}\text { Sub } \\
\text { plot mean }\end{array}$ \\
\hline T1-T. harzianum + P. chlamydosporia & 0.99 & 0.62 & 0.52 & 0.97 & 0.78 \\
T2-Act 2+9 & 0.93 & 0.98 & 0.57 & 0.54 & 0.76 \\
T3-Act 5+9 & 0.51 & 0.50 & 0.3 & 0.40 & 0.54 \\
T4- Metalaxyl-Mancozeb + Carbsosulfan & 0.47 & 0.54 & 0.37 & 0.51 & 0.47 \\
T5-Control & 0.44 & 0.41 & 0.41 & 0.56 & 0.46 \\
Main plot mean & 0.67 & 0.61 & 0.52 & 0.6 & \\
LSD (P<0.05) & & & & & \\
\\
$\mathrm{V}$ & 0.05 & & & & \\
$\mathrm{~T}$ & 0.14 & & & &
\end{tabular}

Table 4. Influence of treatments on root length $(\mathrm{cm})$

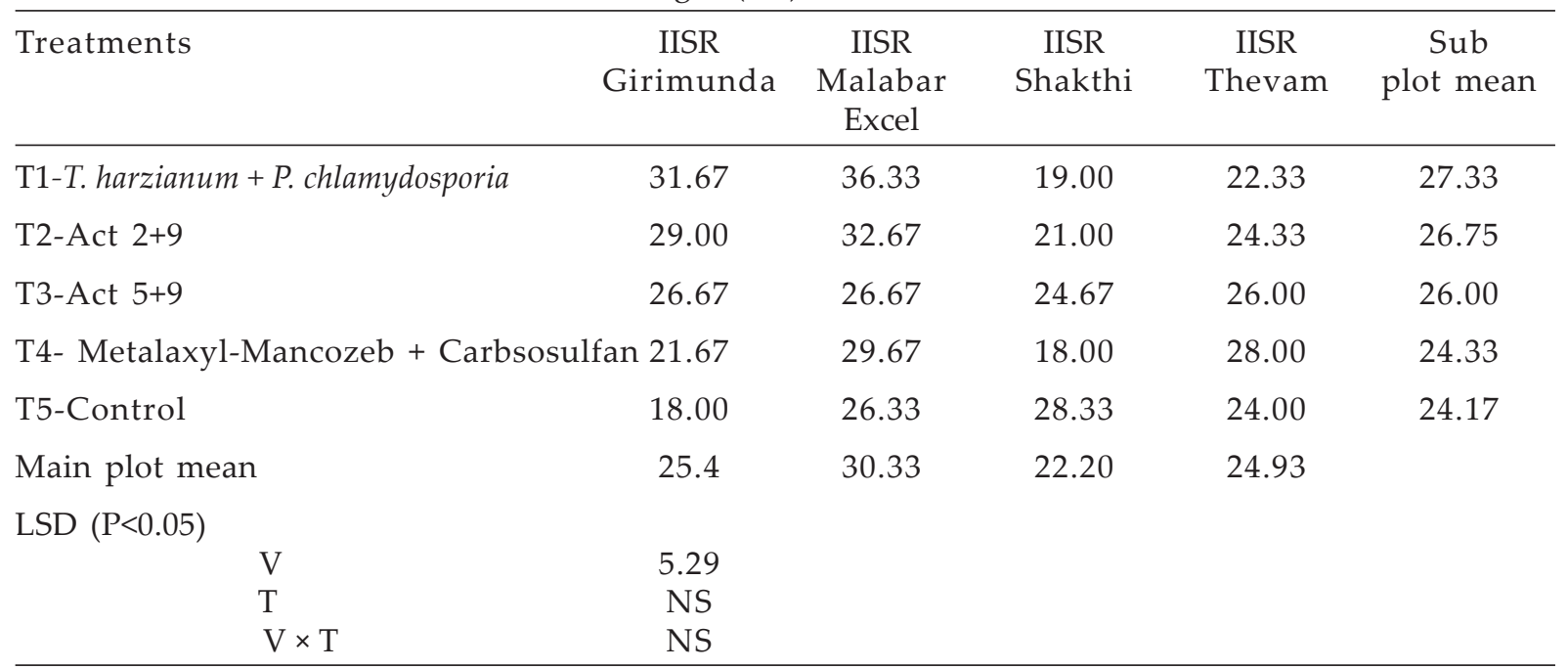


Table 5. Influence of treatments on root fresh biomass (g)

\begin{tabular}{|c|c|c|c|c|c|}
\hline Treatments & $\begin{array}{c}\text { IISR } \\
\text { Girimunda }\end{array}$ & $\begin{array}{c}\text { IISR } \\
\text { Malabar } \\
\text { Excel }\end{array}$ & $\begin{array}{c}\text { IISR } \\
\text { Shakthi }\end{array}$ & $\begin{array}{c}\text { IISR } \\
\text { Thevam }\end{array}$ & $\begin{array}{c}\text { Sub } \\
\text { plot mean }\end{array}$ \\
\hline $\mathrm{T}_{1}-T$. harzianum + P. chlamydosporia & 5.37 & 5.83 & 3.53 & 6.70 & 5.36 \\
\hline $\mathrm{T}_{2}$-Act $2+9$ & 4.37 & 7.07 & 3.83 & 4.23 & 4.88 \\
\hline $\mathrm{T}_{3}$-Act $5+9$ & 2.87 & 4.37 & 5.63 & 3.37 & 4.06 \\
\hline $\mathrm{T}_{4}-$ Metalaxyl-Mancozeb + Carbsosulfan & n 2.47 & 4.07 & 2.93 & 4.00 & 3.37 \\
\hline $\mathrm{T}_{5}$-Control & 2.97 & 3.47 & 3.30 & 3.97 & 3.43 \\
\hline Main plot mean & 3.61 & 4.96 & 3.85 & 4.45 & \\
\hline \multicolumn{6}{|l|}{ LSD $(\mathrm{P}<0.05)$} \\
\hline $\mathrm{V}$ & 0.54 & & & & \\
\hline $\mathrm{T}$ & 1.32 & & & & \\
\hline $\mathrm{V} \times \mathrm{T}$ & NS & & & & \\
\hline
\end{tabular}

Table 6. Effect of treatments on $\mathrm{pH}$ and Dehydrogenase activity

\begin{tabular}{lcccccccc}
\hline Treatments & \multicolumn{3}{c}{ IISR Girimunda } & \multicolumn{2}{c}{$\begin{array}{c}\text { IISR Malabar } \\
\text { Excel }\end{array}$} & \multicolumn{2}{c}{ IISR Shakthi } & \multicolumn{2}{c}{ IISR Thevam } \\
\cline { 2 - 9 } & $\mathrm{pH}$ & DHA & $\mathrm{pH}$ & $\mathrm{DHA}$ & $\mathrm{pH}$ & $\mathrm{DHA}$ & $\mathrm{pH}$ & DHA \\
\hline $\mathrm{T}_{1}$ - T. ha + P. chal & 7.38 & 1.21 & 6.86 & 2.72 & 7.30 & 1.98 & 7.63 & 2.05 \\
$\mathrm{~T}_{2}$ - Act 2+9 & 5.56 & 3.57 & 4.85 & 2.74 & 5.43 & 2.19 & 6.72 & 2.22 \\
$\mathrm{~T}_{3}-$ Act 5+9 & 5.05 & 3.17 & 6.68 & 3.13 & 5.17 & 1.14 & 5.10 & 1.68 \\
$\mathrm{~T}_{4}-$ Met-Mz + Carbosulfan & 6.46 & 2.52 & 5.44 & 1.98 & 4.81 & 0.99 & 6.33 & 1.10 \\
$\mathrm{~T}_{5}-$ Control & 5.64 & 0.94 & 4.55 & 0.96 & 5.66 & 0.53 & 4.86 & 0.61 \\
$\mathrm{CD}(\mathrm{P}<0.05)$ & 0.10 & 0.09 & 0.09 & 0.02 & 0.12 & 0.17 & 0.09 & 0.22
\end{tabular}

such reports are available for the combined use of T. harzianum and P. chlamydosporia for the production of rooted plants of black pepper, except for the individual use of T. harzianum against foot rot and P. chlamydosporia against slow decline diseases. The present study recommend soil solarisation along with the use of Trichoderma + Pochonia combination or combination of Streptomyces strains Act 2+9 for the production of healthy rooted planting material. The effect of solarized potting mixture on growth of black pepper rooted cuttings was reported earlier (Thankamani et al. 2007). Since both Phytophthora and nematodes are serious threats of black pepper, the treatment combinations are made in such a way that the combination contain one antagonist against Phytophthora and another antagonist against nematode. Similar work was reports for the use of consortia in planting material production. Consortia of P. fluorescens $+T$. harzianum + Paecilomyces lilacinus were used for the production of tomato seedlings for combating nematode infection (Mukhtar 2013) and P. fluorescens $+T$. harzianum for the production of nematode free papaya seedlings (Rae 2007). The promotive effects of Pseudomonas and Trichoderma were quite significant in growth promotion in tomato during nursery and crop growth stages (Kumar et al. 2007). Similarly, 
Mukhtar (2013) reported the biocontrol potential of Pasteuria penetrans, P. chlamydosporia, P. lilacinus and T. harzianum against Meloidogyne incognita in okra.

\section{Acknowledgements}

The authors are thankful to Department of Agriculture for funding, Mr. George Nedumkallel, farmer at Omasserry, Kerala State for active cooperation and involvement in supporting the nursery trial, Mr. K. Jayarajan, Chief Technical Officer for statistical analysis of the data and Mr. Vishnu P T for constant support in monitoring of the nursery.

\section{References}

Kumar Sunil, Arya M C \& Singh Ranjit 2007 Efficiency of Pseudomonas fluorescens and Trichoderma harzianum as bio-enhancers in tomato at high altitude in central Himalayas. Indian J. Crop Sci. 2: 79-82.

Liang Q, Chen H, Gong Y, Yang H, Fan M \& Kuzyakov Y 2014 Effects of 15 years of manure and mineral fertilizers on enzyme activities in particle-size fractions in a North China Plain soil. Europ. J. Soil Biol. 60: 112-119.
Mukhtar T, Hussain M A \& Kayani M Z 2013 Biocontrol potential of Pasteuria penetrans, Pochonia chlamydosporia, Paecilomyces lilacinus and Trichoderma harzianum against Meloidogyne incognita in okra. Phytopathologia mediterranea 52: 66-76.

Rao M S 2007 Papaya seedlings colonized by the bio-agents Trichoderma harzianum and Pseudomonas fluorescens to control root-knot nematodes. Nematol. Medit. 35: 199-203.

Suseela Bhai R, Lijina A, Prameela T P, Krishna P B \& Anusree Thampi 2016 Biocontrol and growth promotive potential of Streptomyces spp. in black pepper (Piper nigrum L.). J. Biol. Control 30: 2016.

Thankamoni C K, Sreekala K \& Anandaraj M 2005 Effect of Pseudomonas fluorescens (IISR-6) and Trichoderma harzianum (P-26) on growth of black pepper (Piper nigrum L.) in the nursery. J. Spices Arom. Crops 14: 112-116.

Thankamani C K, Dinesh R, Eapen S J, Kumar A, Kandiannan K \& Mathew P A 2008 Effect of solarized potting mixture on growth of black pepper rooted cuttings (Piper nigrum L.) in the nursery. J. Spices Arom. Crops 17: 103-108. 


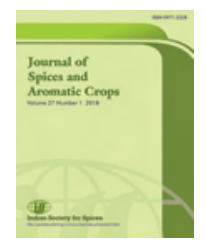

\title{
Diversity in floral characters of monoecious nutmeg (Myristica fragrans Houtt.)
}

\author{
S Aarthi*, J Rema, B Sasikumar, K V Saji \& M Anandaraj \\ ICAR-Indian Institute of Spices Research, Kozhikode-673 012, Kerala. \\ *E-mail: aarthichandru@gmail.com
}

Received 05 December 2017; Revised 04 April 2018; Accepted 10 April 2018

\begin{abstract}
Floral diversity in monoecious type nutmeg reveals three types of flowers namely; pistillate, staminate and hermaphrodite flowers. The structure of hermaphrodite flowers in nutmeg is reported for the first time. The flowers are borne on the leaf axil, flowering habit of the three types of flowers are seen in cymes as well as solitary in the same tree. The gynoecium consists of single ovary with bifid stigma in the pistillate flowers and the androecium of staminate flowers has adnate 7-13 anthers. Intra flower variability is evident in case of hermaphrodite flowers. In hermaphrodite flower the androecium ranges with 1-4 anthers, in the form of fused filament or free filament or both; some anthers are fused with the gynoecium. Besides remnants of the stamen in the developed fruits of hermaphrodite flowers, staminodes are also observed in the flowers. Colour of all the three types of flowers are light creamy yellow, with thick gamosepalous perianth which bursts as bilobed, trilobed, tetralobed and pentalobed lobes during anthesis. Analysis of variance of trees for flower types and floral attributes like flower type, number of anthers, length of anthers, length of filaments and length of ovary are found to be highly significant. High coefficient of variation is recorded for hermaphrodite $(183.84 \%)$ and pistillate $(171.71 \%)$ flowers. The pollen viability of the hermaphrodite flowers are found less as compared to the staminate flowers. The percentage of pollen viability is 79.74 and 90.77 in hermaphrodite and male flower respectively. In the population studied, the occurrence of hermaphrodite flower in monoecious tree ranged from $0-10 \%$.
\end{abstract}

Keywords: hermaphrodite flowers, intra floral variability, monoecious, Myristica fragrans Houtt., pollen viability

Nutmeg (Myristica fragrans Houtt.) (Myristicaceae) is an important tree spice, yielding two spices, namely, the nutmeg (dried seed) and the mace (dried aril surrounding the seed). Nutmeg is hitherto considered to be predominantly dioecious in nature (Flach 1966). However, of late this concept is undergoing a paradigm shift, as monoecious trees are being reported often across the country (Krishnamoorthy et al. 1996; Krishnamoorthy et al. 2012; Rema et al. 2014). Though some literature is available on the reproductive biology of dioecious nutmeg (Armstrong \& Drummond 1986), there is no report available for monoecious nutmeg trees. 
Here we attempt to study the floral diversity of monoecious nutmeg.

The study on sex differentiation and variability in monoecious nutmeg was carried out at ICAR-Indian Institute of Spices Research (IISR), Kozhikode during June to September 2015. Total of 53 trees of 18 year old were selected randomly from the germplasm maintained at ICAR IISR and were studied for sex of tree from December 2014 onwards. The sex of flowers were recorded in all the trees at monthly interval. Out of the 53 trees of the selected population 6 trees are found to be monoecious. These 6 monoecious trees are used in the present study.

Details of 6 monoecious trees conserved at ICAR-IISR, Chelavoor:

\begin{tabular}{|c|c|c|}
\hline $\begin{array}{l}\text { Plant } \\
\text { number }\end{array}$ & Source & $\begin{array}{l}\text { Nature of } \\
\text { plant }\end{array}$ \\
\hline C- 1 & $\begin{array}{l}\text { ICAR-IISR, } \\
\text { Experimental Farm, } \\
\text { Peruvannamuzhi }\end{array}$ & Seedling \\
\hline C- 9 & $\begin{array}{l}\text { ICAR-IISR, } \\
\text { Experimental Farm, } \\
\text { Peruvannamuzhi }\end{array}$ & Seedling \\
\hline C- 21 & $\begin{array}{l}\text { ICAR-IISR, } \\
\text { Experimental Farm, } \\
\text { Peruvannamuzhi }\end{array}$ & Seedling \\
\hline C- 43 & $\begin{array}{l}\text { ICAR-IISR, } \\
\text { Experimental Farm, } \\
\text { Peruvannamuzhi }\end{array}$ & Seedling \\
\hline$C-45$ & $\begin{array}{l}\text { ICAR-IISR, } \\
\text { Experimental Farm, } \\
\text { Peruvannamuzhi }\end{array}$ & Seedling \\
\hline C -54 & Farmers field Ankola & Seedling \\
\hline
\end{tabular}

Within the 6 monoecious trees observations on inter and intra floral variability in monoecious for anther length, number of anthers, filament length, ovary length and flower opening type were recorded. Total of 100 flowers / month were collected from each tree and observations were recorded for variability during peak flowering season June - September, 2015.
Pollen viability test was done using Acetocarmine staining method. Pollen viability estimated using glyceroacetocarmine (Marks 1954). The pollen viability percentage determined as the ratio of the number of viable pollen to the total pollen number.

ANOVA for the floral attributes were done using SAS 9.3 software.

Based on the observations made on the phenological measurements inter and intra flower variability in monoecious nutmeg flowers are prominent. Three types of flowers are recorded in monoecious trees namely, pistillate, staminate and hermaphrodite flowers. The structure of hermaphrodite in nutmeg is reported for the first time. The flowers are borne on the leaf axil, flowering habit of the three types of flowers are seen in cymes as well as solitary in the same tree. All the types of flowers were light creamy yellow colour in monoecious tree, with thick gamosepalous perianth which bursts as trilobed or bilobed (less frequent) lobes during anthesis as reported earlier (Armstrong \& Drummond 1986). However, addition to this tetralobed and pentalobed are observed rarely in monoecious trees (Fig. 1). Tetralobed lobes are reported in $M$. fatua, this type of lobe opening helps in more access for insects (pollinators) to enter the flower (Sharma \& Armstrong 2013). The androecium of staminate flowers consisted of adnate 7-13 anthers, with average of 9.30 anthers and 4.09 and $3.18 \mathrm{~mm}$ of anther length and filament length respectively, androecium with 8-10 anthers were reported earlier by Armstrong \& Drummond (1986) in staminate flowers. The gynoecium consists of single ovary with a mean length of $5.28 \mathrm{~mm}$ with bifid stigma in the pistillate flowers (Tables 1 \& 2). Intra flower variability is evident in case of hermaphrodite flowers. In hermaphrodite flower the androecium ranges with 1-4 anthers, in the form of fused filament or free filament or both; some anthers are fused with the gynoecium (Fig. 2); the length of the anther varies from 3$6 \mathrm{~mm}$. Besides remnants of the stamen in the developed fruits of hermaphrodite flowers, staminodes are also observed in the flowers (Fig. 


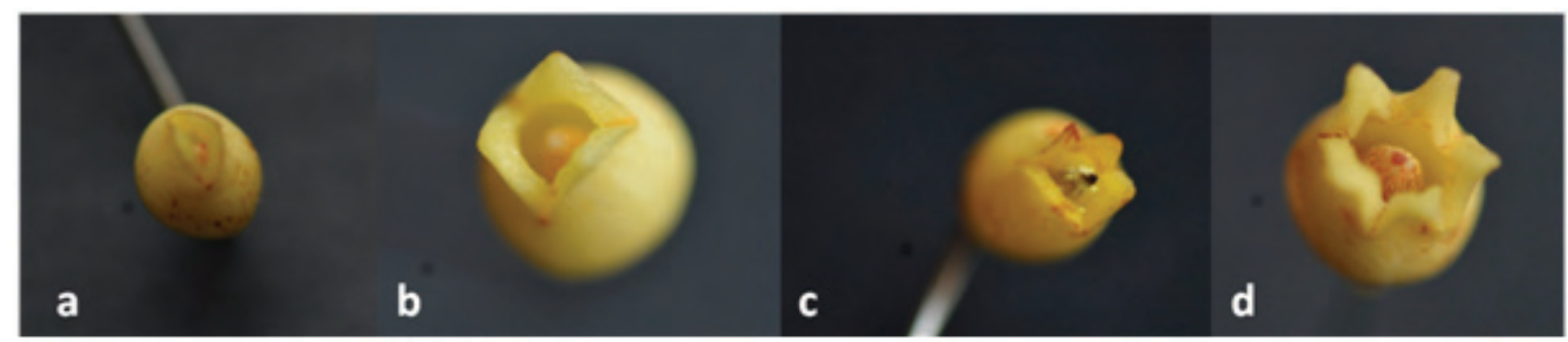

Fig. 1. Variation in flower opening in monoecious tree flowers [a) Dimerous, b) Trimerous, c) Tetramerous and d) Pentamerous]

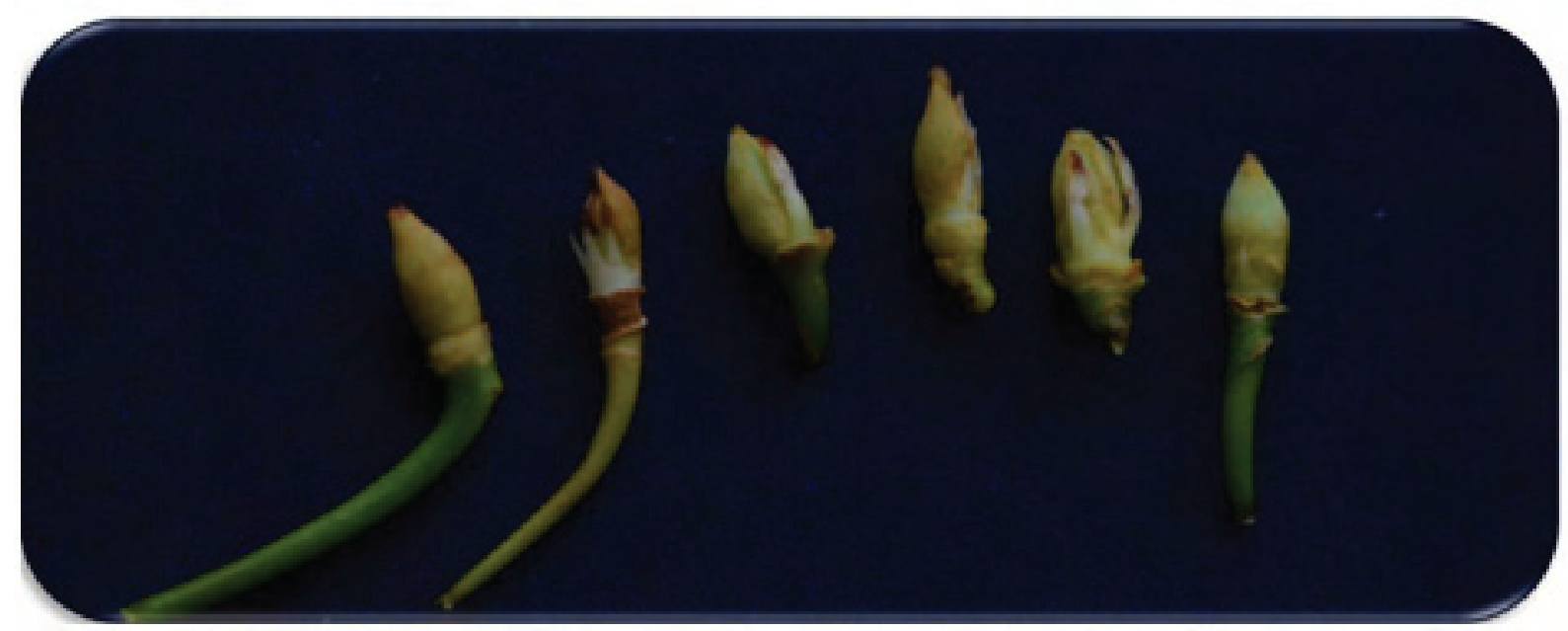

Fig. 2. Intra flower variability in number and length of anthers of hermaphrodite flowers

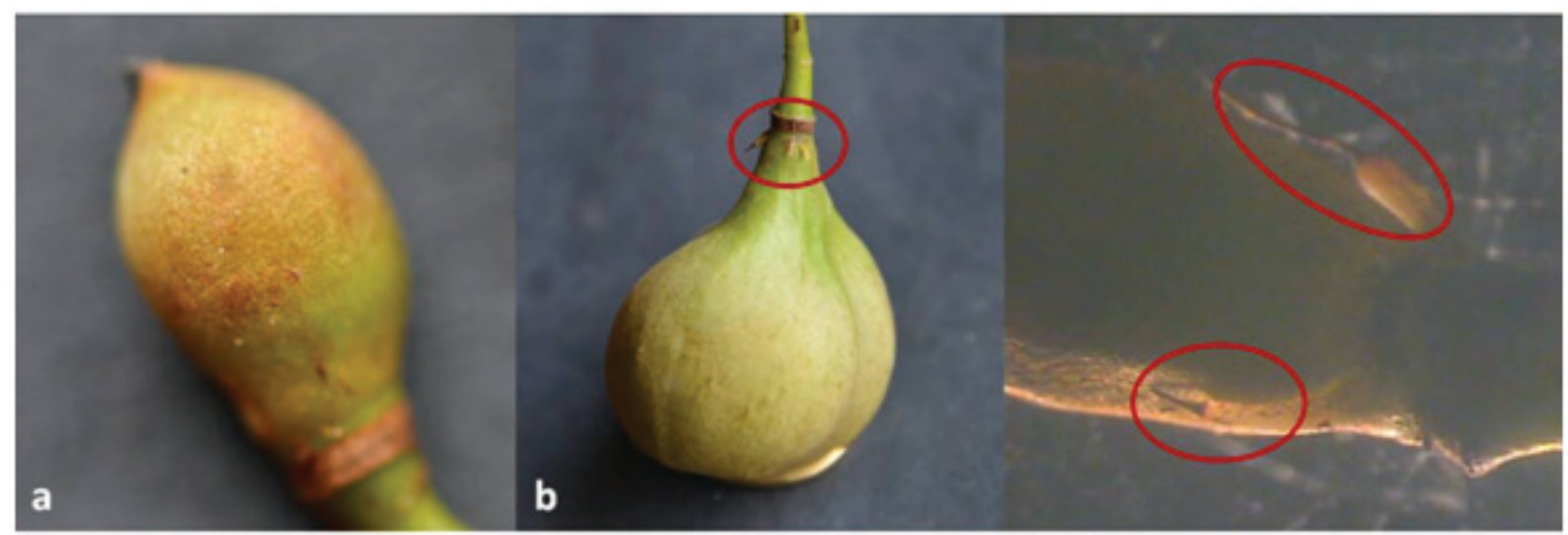

Fig. 3. Developed fruits from monoecious trees [a) from pistillate flowers, b) from hermaphrodite flowers (remnants of the stamen) and c) Microscopic view (20x)] 
3). Analysis of variance of trees for flower types and floral attributes like flower type, number of anthers, length of anthers, length of filaments and length of ovary are found to be highly significant (Table 1). High coefficient of variation is recorded for hermaphrodite $(183.84 \%)$ and pistillate (171.71\%) flowers (Table $2)$. The pollen viability of the hermaphrodite flowers are found less as compared to the staminate flowers. The percentage of pollen viability is 79.74 and 94.77 in hermaphrodite and male flower respectively (Table 3 ). In the population studied, the average segregation of staminate, pistillate and hermaphrodite flower in the collected samples is 87.72, 19.22 and 5.77, respectively with approximate ratio of 17: 4:1. The occurrence of hermaphrodite flower in monoecious tree ranged from $0-9 \%$. In $90 \%$ of the flowers studied the stamen length is found shorter than the stigma thereby excluding the chance of selfing. Moreover the pollen viability is also found less in these flowers. Variability in flowering phenology among individuals has direct impact on their fitness (Mauricio et al. 2013). However, the influence of environment factors on sex expression and floral variability need to be studied in detail in nutmeg.

\section{Acknowledgments}

First author is grateful to Dr. R. Ramakrishnan Nair (Genetics \& Cytogenetics), for his scientific and timely suggestions. We also acknowledge Mr. K. Jayarajan for statistical analysis and Mr. A. Sudhakaran for photography.

\section{References}

Armstrong J E \& Drummond B A 1986 III Floral biology of Myristica fragrans Houtt. (Myristicaceae), the nutmeg of commerce. Biotropica 18: 32-38.

Flach M 1966 Nutmeg cultivation and its sex problem. Mededelingen Landbouwhogeschool. Wageningen 66: 185.

Krishnamoorthy B, Sasikumar B \& Rema J 1996 Genetic variability and segregation of sex in nutmeg (Myristica fragrans Houtt.). J. Plant. Crops 24: 468-472. 
Table 2. Mean, range and $C V \%$ for floral traits in monoecious nutmeg

\begin{tabular}{lllll}
\hline Category & Characters & Mean & Range & CV\% \\
\hline Sex of flowers & Staminate & 88.37 & $50-100$ & 21.33 \\
& Pistillate & 9.11 & $0-50$ & 171.71 \\
& Hermaphrodite & 2.74 & $0-15$ & 183.84 \\
Staminate & No. of anther & 9.30 & $7-13$ & 11.49 \\
& Length of anther $(\mathrm{mm})$ & 4.09 & $3-6$ & 20.25 \\
Pistillate & Length of filament $(\mathrm{mm})$ & 3.18 & $2-4$ & 16.74 \\
Hermaphrodite & Length of ovary $(\mathrm{mm})$ & 5.42 & $5-6$ & 8.28 \\
& No. of anther & 2.22 & $1-4$ & 43.58 \\
& Length of ovary $(\mathrm{mm})$ & 5.31 & $4-6$ & 9.54 \\
\hline
\end{tabular}

Table 3. Pollen viability in staminate and hermaphrodite flowers of monoecious nutmeg

\begin{tabular}{lllll}
\hline Flower type & $\begin{array}{l}\text { Number of pollens } \\
\text { observed }\end{array}$ & Viable pollen & Sterile pollen & $\%$ of viability \\
\hline Staminate flower & 152.66 & 145.00 & 7.67 & 94.77 \\
Hermaphrodite flower & 124.33 & 104.33 & 20.00 & 79.74 \\
\hline
\end{tabular}

Krishnamoorthy B, Rema J, Nair R R \& Krishnamurthy K S 2012 Circumventing sexual dimorphism in nutmeg - an innovation by Shri. Purnanand V. Bhat. Spice India 25: 8-10.

Marks G E 1954 An aceto-carmine glycerol jelly for use in pollen fertility counts. Stain Technol. 29: 277.

Mauricio Fernandez Otarola, Marlies Sazima \& Vera N Solferini 2013 Tree size and its relationship with flowering phenology and reproductive output in wild nutmeg trees. Ecol. Evol. 3: 3536-3544.

Rema J, Saji K V, Sasikumar B \& Anandaraj M 2014 Monoecious nutmeg in Uttarkannada and Shimoga Districts of Karnataka. Indian J. Arec. Spices Med. Plants 16: 3-5.

Sharma M V \& Armstrong J E 2013 Pollination of Myristica and other nutmegs in natural populations. Trop. Conserv. Sci. 6: 595-607. 


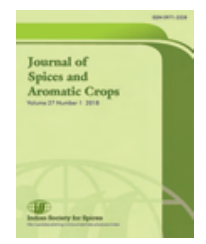

\title{
Air layering in cinnamon (Cinnamomum verum L.) under wet humid tropical conditions
}

\author{
A A Waman* \& P Bohra \\ Division of Horticulture and Forestry, \\ ICAR-Central Island Agricultural Research Institute, Port Blair-744 101, Andaman \& Nicobar. \\ *E-mail: ajit.hort595@gmail.com
}

Received 08 April 2017; Revised 07 March 2018; Accepted 26 March 2018

\begin{abstract}
Cinnamon is a cross pollinated species and seed propagation has resulted in development of considerable variability in growth, yield and quality among the populations. Air layering has been considered as one of the efficient methods of multiplication in cinnamon. However, the success of layering varies greatly depending on the local environmental conditions. In the present investigation, air layering was performed at 20 days interval during rainy season (July $3^{\text {rd }}$ to October $11^{\text {th }}$ ) of two consecutive years in Bay islands. Result revealed that first week of July was the most suitable time for air layering in cinnamon as it supported better rooting percentage $(87.5 \%)$.
\end{abstract}

Keywords: Propagation; Season; Spice crop; Tropical islands

Cinnamon (Cinnamomum verum L.) or dalchini is one of the ancient tree spices grown in India. Though both bark as well as leaves are known to possess aromatic components mainly cinnamaldehyde and eugenol, the bark of this species is valued as a spice. It has been used in the form of dried bark, bark powder, oil and oleoresins. Cultivation of this spice in India is mainly confined to States of Andaman and Nicobar Islands, Kerala, Karnataka, North Eastern India and parts of Tamil Nadu and Maharashtra. Combined estimate of cinnamon and tejpat suggests that in India, it's being grown on 2,770 ha area with about $5,050 \mathrm{t}$ production (Indian Horticulture Database 2014). However, the production is not enough to meet the domestic demand and hence, cinnamon is being imported from other countries of the world (Indian Spices 2016). Increasing the productivity through development and adoption of improved technologies is a key factor in reducing the dependence on import.

Soil and climatic conditions of the Andaman and Nicobar Islands are well suited for the cultivation of cinnamon (Parthasarathy et al. 2009) and presently it is cultivated in about 150 ha yielding $40 \mathrm{t}$ annually. Quality of cinnamon is assumed to be the finest in the islands compared with other parts of the country (Singh \& Sankaran 2012). Large availability of interspaces in the coconut and arecanut plantations in the Andaman and Nicobar 
Islands could be successfully utilized for its cultivation (Waman et al. 2016). However, existing plantations in the islands are of seedling origin. One can easily notice variations in cinnamon seedlings for leaf size, shape and colour of new flush, apart from the distinct chemotypes (Krishnamoorthy et al. 1988). Ergo, considerable variability is noticed in the yields and quality of the final produce and hence, vegetative propagation is of interest (Rema et al. 1997). The present report concerned an effort to identify the most appropriate time for carrying out air layering under island condition.

The present investigation was carried out in the Division of Horticulture and Forestry of ICAR- Central Island Agricultural Research Institute, Port Blair, Andaman and Nicobar Islands during 2015 and 2016. The islands exhibit typical tropical climate with average temperature of $18-31^{\circ} \mathrm{C}$ and annual rainfall of 3,100 mm distributed over May to December. Further, the relative humidity ranges between $60-90 \%$ in a year, while the average lies near to $70-80 \%$.

For layering, healthy shoots of $25-30 \mathrm{~cm}$ length and 1.0-1.5 cm thickness were selected. Leaves and small branches near the ringing area on selected shoots were removed and two circular cuts were given to the shoots for removing a ring of bark of about an inch width.
Commercial formulation of rooting hormone (Lipsa, Kolkata) was used for root induction and ringed portion was covered with soil: farmyard manure (1:1) before wrapping with polythene $(20 \mathrm{~cm} \times 20 \mathrm{~cm})$. Experiment consisted of six treatments i.e. $\mathrm{T}_{1}$ : layering on July $3, \mathrm{~T}_{2}$ : layering on July $23, \mathrm{~T}_{3}$ : layering on August 12, $\mathrm{T}_{4}$ : layering on September 1, $\mathrm{T}_{5}$ : layering on September 21 and $\mathrm{T}_{6}$ : layering on October 11. Experiment was laid out in completely randomized design with 20 layers in each treatment. Various parameters were recorded at the time of separation (90 days after layering) and data was subjected to analysis of variance using Web Agri Statistical Package 2.0 (WASP 2.0, ICAR-RC for Goa, Ela, India).

Air layering was performed for six times during rainy season under island condition. Generally, rooting process is facilitated by the rains (Ranaware et al. 1995) and hence, the dry periods in the islands were avoided during the experimentation. Pooled analysis of two years data revealed that percentage root induction varied between $35.0 \%$ and $87.5 \%$ amongst the treatments studied (Table 1). Maximum rooting percentage was obtained in layers done on $3^{\text {rd }}$ July $(87.5 \%)$ followed by those done on $23^{\text {rd }}$ July, while it was the lowest in layering performed on $21^{\text {st }}$ September. Though rooting response varied considerably during different seasons, the mean number of primary roots per layer did not vary significantly (Table 1 ).

Table 1. Air layering in cinnamon under Andaman condition as affected by time of layering (pooled data of two years)

\begin{tabular}{lcccc}
\hline Treatment & $\begin{array}{c}\text { Rooting } \\
\text { percentage }\end{array}$ & $\begin{array}{c}\text { Number of } \\
\text { primary roots } \\
\text { layer }\end{array}$ & $\begin{array}{c}\text { Mean length } \\
\text { of primary } \\
\text { root (cm) }\end{array}$ & $\begin{array}{c}\text { Mean thickness } \\
\text { of primary } \\
\text { root (mm) }\end{array}$ \\
\hline July 3 & 87.5 & $5.8 \mathrm{a}$ & $5.52 \mathrm{~b}$ & $2.74 \mathrm{a}$ \\
July 23 & 57.5 & $4.2 \mathrm{a}$ & $7.37 \mathrm{a}$ & $2.33 \mathrm{a}$ \\
August 12 & 47.5 & $4.2 \mathrm{a}$ & $5.18 \mathrm{bc}$ & $2.04 \mathrm{a}$ \\
September 1 & 50.0 & $3.7 \mathrm{a}$ & $8.53 \mathrm{a}$ & $2.17 \mathrm{a}$ \\
September 21 & 35.0 & $5.3 \mathrm{a}$ & $3.60 \mathrm{c}$ & $2.15 \mathrm{a}$ \\
October 11 & 43.2 & $3.8 \mathrm{a}$ & $4.00 \mathrm{bc}$ & $2.20 \mathrm{a}$ \\
\hline
\end{tabular}

${ }^{*}$ Means followed by same alphabet in a column do not differ significantly at $5 \%$ level of significance using least significant difference 
Length of longest root varied significantly amongst the studied treatments (Table 1). Maximum length of primary root was observed in propagules obtained from cinnamon layered on $1^{\text {st }}$ September $(8.5 \mathrm{~cm})$, which remained on par with layers of $23^{\text {rd }}$ July. Similar to rooting percentage, length of root was found to be the lowest $(3.6 \mathrm{~cm})$ in layers of $21^{\text {st }}$ September batch. Thickness of root ranged from 2.04 to $2.74 \mathrm{~mm}$; however, the differences were non-significant amongst the treatments studied.

Similar to present communication, significant variations for rooting response and growth parameters have been reported from different agro-ecological regions of the country viz., West Bengal (Banerjee et al. 1982), Karnataka (Hegde et al. 1989) and Maharashtra (Ranaware et al. 1995). These reports have suggested the positive effects of rainy period on layering success; however, the raining season and pattern vary significantly in different regions and hence, location specific studies are required. As no reports are available for island conditions, present study was conducted. The prevalence of optimum microclimate during the part of the year would possibly have helped in maximizing the rooting success. Rema et al. (1997) reviewed different propagation methods in spice crops in which they supported the possible role of endogenous auxins, sugars and other biochemical constituents in variable rooting success during different seasons.

It could be concluded that first week of July is the most suitable time for carrying out air layering under Andaman and Nicobar Islands condition. This technique being easier, farmers can easily multiply superior types in large number. In addition, inputs required for the purpose are easily available at cheaper cost and hence, it could be a boon for on farm production of quality planting material in the Andaman Islands.

\section{Acknowledgements}

Authors are thankful to the Director of the Institute for providing necessary facilities for conducting the experiment.

\section{References}

Banerjee D P, Chatterjee B K \& Sen S 1982 Air layering of cinnamon (Cinnamomum zeylanicum). South Indian Hort. 30: 272-273.

Hegde K P, Sulikeri G S \& Hulamani N C 1989 Effect of growth regulators and pre-girdling treatments on rooting of cinnamon air layers. South Indian Hort. 37: 329-332.

IHD 2014 Indian Horticulture Database, National Horticulture Board, Gurgaon, India, 286 p.

Indian Spices 2016 http://indianspices.com/sites/ default/files/Major\%20Item \%20wise \%20 Import-2016.pdf.

Krishnamoorthy B, Gopalam A \& Abraham J 1988 Quality parameters of cinnamon (Cinnamomum verum) in relation to flush colour. Indian Cocoa Arec. Spices J. 12: 38.

Parthasarathy V A, Srinivasan V \& Prasath D 2009 Status and strategies of spices cultivation in island ecosystem. In: Souvenir and abstract book, National workshop cum seminar on status and future strategies of horticulture development in A \& N Islands held on 23$25^{\text {th }}$ January, 2009, CARI, pp.24-35.

Ranaware V S, Nawale R N, Khandekar R G \& Magdum M B 1995 Effect of season on air layering of cinnamon. Indian Cocoa Arec. Spices J. 19: 81-84.

Rema J, Krishnamoorthy B \& Mathew P A 1997 Vegetative propagation of major tree spicesa review. J. Spices Arom. Crops 6: 87-105.

Singh D R \& Sankaran M 2012 Problems and prospects of cultivation of spices and plantation crops in Andaman and Nicobar Islands. In: Souvenir cum abstract book, National Seminar on Technologies for improving productivity of spices and plantation crops. February 27-28, 2012, CARI, Port Blair, 81p.

Waman A A, Bohra P, Avinash N, Gautam R K \& Dam Roy S 2016 Air layering in cinnamon (Cinnamomum verum) in the context of Andaman and Nicobar Islands. Extension Folder, ICAR-Central Island Agricultural Research Institute, Port Blair, pp.1-6. 


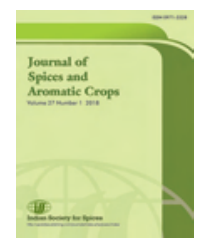

Stability analysis for seed yield and yield attributing traits in fennel (Foeniculum vulguare Mill.)

\author{
S L Sawargaonkar*, A K Singh \& S Sahu \\ College of Agriculture E Research Station, Indira Gandhi Krishi Vishwavidyalaya, \\ Raigarh-496 001, Chhattisgarh. \\ *E-mail: shrikant.sawargaonkar@gmail.com
}

Received 03 October 2018; Revised 30 April 2018; Accepted 02 May 2018

\begin{abstract}
Study was carried to evaluate phenotypic stability of 13 genotypes of fennel for seed yield and yield attributing traits. Out of 13 genotypes, three were checks (RF 205, RF 201 and local fennel) grown in Randomized Block Design (RBD) with three replications in each year. The significant genotypic differences were observed for all the characters suggesting differential responses of genotypes to the environmental changes. The results showed that among 13 genotypes RF 205 and Local fennel were found stable for seed yield plant ${ }^{-1}$, FNL 69 for days to flower, FNL 70 and RF 101 for primary branches plant ${ }^{-1}$, FNL 74 for umbels umbellet ${ }^{-1}$ and FNL 71 for umbels plant ${ }^{-1}$. The results revealed that some reliable predictions about $G \times E$ interaction as well as its unpredictable components contributed significantly in determining the stability of genotypes. The wider stability recorded by RF 205, RF 201 and local fennel during all the three years which will be useful for development of high yielding varieties of fennel.
\end{abstract}

Keywords: fennel, Foeniculum vulguare mill., stability, superiority

Fennel (Foeniculum vulguare mill.) is a highly cross pollinated and very important seed spice crop exhibiting $82.2 \%$ to $91.4 \%$ natural out crossing (Ramanujam et al. 1964). The hybridization of diverse genotypes followed by selection in segregating crop will be helpful in identifying heterozygous and heterogenous progeny. Insects plays an important role in maintaining heterogeneity in fennel crop. The existing varieties were developed using mass selection. Fennel seeds are having medicinal importance as carminative, cardiotonic, stimulant, vermicide and lactagogue (Lal 2014). The research efforts were for enhancing the productivity through developing high yielding inbreds and pure line varieties. India is the largest producer, consumer and exporter of spices and spice products. The total production of spices during 2013-14 was 5.9 MT from an area of 3.16 million ha (Annual Report 201415). Fennel had very little share to total production of spices. This yield gap can be minimized by growing suitable cultivars with appropriate packages of practices. For this development of high yielding and insect and pest resistant with good quality stable variety is essential. The newly variety must perform consistent performance across the 
environments and over the years for high yield and other yield attributing and quality traits. Phenotypically stable genotypes are of great importance because environmental conditions vary from season to season. Wider adaptation to a particular environment and consistent performance of recommended genotypes is one of the main objectives in breeding programme. A differential response of fennel genotypes when grown under different environments in the Rabi season has been reported by few scientists (Lal 2014; Drazic et al. 2014). Hence information on availability of stable high yielding varieties of Fennel is lacking. Keeping this in view, the present investigation was undertaken to determine the genotype $x$ environment (year) interaction on stability parameters and to identify the stable and responsive genotypes for yield and yield contributing characters of fennel for Chhattisgarh.

The experimental materials consisted of 13 genotypes obtained from All India Coordinated Research Project (AICRP) on spices, Indian Institute of Spices Research (IISR), Kozhikode, Kerala, evaluated for stability of seed yield and yield attributing traits for the three years during 2012-13 to 2014-15 at the experimental farm of College of Agriculture and Research Station (CARS), Raigarh $\left(21.9^{\circ} \mathrm{N}, 83.4^{\circ} \mathrm{E}, 215\right.$ $\mathrm{m})$, Indira Gandhi Krishi Vishwavidyalaya (IGKV), Chhattisgarh. Out of 13 genotypes RF 205, RF 201 and local fennel were standard checks grown in Randomized Block Design (RBD) with three replications. Twenty plants in each row in plot size of $4 \times 2.5 \mathrm{~m}$, were maintained after thinning. The inter- and intrarow spacing was kept at $45 \mathrm{~cm}$ and $20 \mathrm{~cm}$, respectively. The recommended package of cultural practices was followed to raise a good crop. In each plot, five competitive plants were identified randomly for recording data on days to $50 \%$ flowering, plant height $(\mathrm{cm})$, primary branches plant $^{-1}$, umbels plant ${ }^{-1}$, umblets umbel ${ }^{-1}$ and seed yield plot $^{-1}(\mathrm{~kg})$. The data recorded during three years were subjected to stability analysis according to the model proposed by Eberhart \& Russel (1966) and three stability parameters mean (m), regression coefficient (bi) and the deviation from linearity $\left(S^{2}\right.$ di) were estimated.

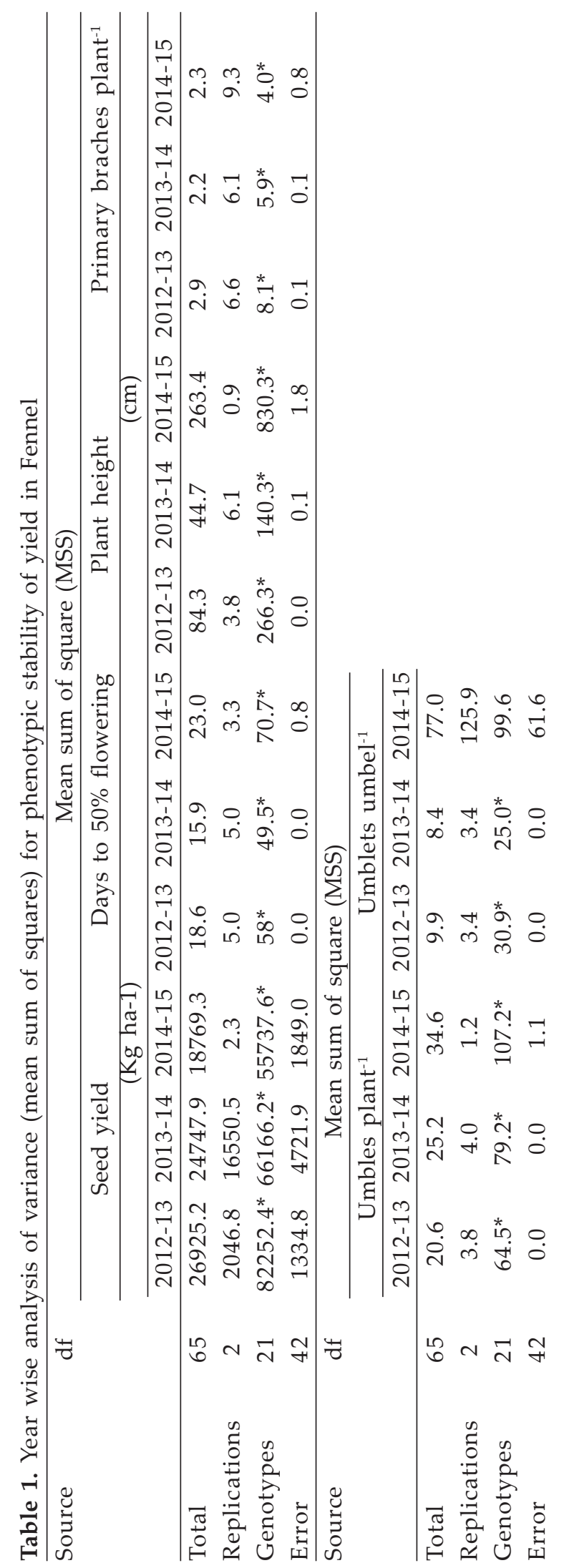


The genotypic differences were found to be highly significant for all the traits in each environment (year). The mean genotypic values from different year were subjected to pooled analysis. The mean sum of squares (MSS) due to genotypes $(\mathrm{G})$ and environments (E) were significant for all the traits except for primary branches plant ${ }^{-1}$ when tested against MSS due to genotype $x$ environments. It revealed the non significant differential response of the varieties to the changing environments. The results were in close conformity to the findings of Lal (2008), Verma \& Solanki (2015). The MSS due to $G \times E$ when tested against pooled error, were found highly significant for all the characters. Thus stability analysis was carried out for all the traits. The variance due to $\mathrm{G} \times \mathrm{E}$ were divided in to $G \times E$ (Linear) and due to pooled deviation (Non-linear). The $\mathrm{G} \times \mathrm{E}$ (Linear) mean squares were found significant for all the traits except primary branches plant $^{-1}$ indicating the presence of predictable components where as significance of pooled deviation for seed yield plot ${ }^{-1}$, days to $50 \%$ flowering, plant height $(\mathrm{cm})$, primary branches plant $^{-1}$ and umbels plant ${ }^{-1}$ showed the presence of non-predictable components. These observations indicated that some reliable predictions about $G \times E$ interaction as well as its unpredictable components can be made for these traits. Hence, both components contributed significantly in determining the stability of genotypes (Lal 2008; Verma \&
Solanki 2015). Among 13 genotypes RF 205 and Local fennel were found stable for seed yield plant $^{-1}$, FNL 69 for days to flower, FNL 70 and RF 101 for primary branches plant ${ }^{-1}$, FNL 74 for umbels umbel ${ }^{-1}$ and FNL 71 for umbels plant $^{-1}$ (Table 2).

For days to flower, umbelets /umbel and umbels plant $^{-1}$ FNL 69 had recorded wider stability (above average mean, bi $=1$ and $S^{2} d i=0$ ). The genotype FNL 70 was stable for plant height, primary branches plant ${ }^{-1}$, umbelets umbel ${ }^{-1}$ and umbels plant ${ }^{-1}$ but had low seed yield, indicating its adaptation to stress environments (Lal 2008) while genotype FNL 71 recorded stability for plant height and umbels plant ${ }^{-1}$. For umbels umbel ${ }^{-1}$ FNL 72 had high stability across the environments of Raigarh. The genotypes FNL 69, FNL 70 and FNL 71 were among the top entries which had their mean umbels plant ${ }^{-1}$ greater than the average of all the genotypes with regression coefficient (bi $=1$ ) and non-significant deviation for regression $\left(\mathrm{S}^{2} \mathrm{di}=0\right)$. This indicated their high stability over the different environments of years (Lal 2008). The genotype FNL 68 and RF 101 had above average mean for umbels plant ${ }^{-1}, S^{2} \mathrm{di}=0$ but the value of bi \#1, indicating their adaptation to high input conditions. For umbels plant ${ }^{-1}$ genotype RF 205 and FNL 67 had bi = 1 and $\mathrm{S}^{2} \mathrm{di}=0$, but their mean was low, indicating their adaptation to stress environments (Table $3)$.

Table 2. Analysis of variance (mean squares) for phenotypic stability of yield and yield contributing characters in Fennel

\begin{tabular}{|c|c|c|c|c|c|c|c|}
\hline \multirow[t]{2}{*}{ Source } & \multirow[t]{2}{*}{$\mathrm{df}$} & \multicolumn{6}{|c|}{ Mean square } \\
\hline & & $\begin{array}{l}\text { Seed yield } \\
\left(\mathrm{kg} \mathrm{ha}^{-1}\right)\end{array}$ & $\begin{array}{l}\text { Days to } \\
50 \% \text { flow }\end{array}$ & $\begin{array}{l}\text { Plant } \\
\text { height }\end{array}$ & $\begin{array}{l}\text { Prim. } \\
\text { Branch }\end{array}$ & $\begin{array}{l}\text { Umbels }^{-1} \\
\text { plant }\end{array}$ & $\begin{array}{l}\text { Umblets } \\
\text { umbel }^{-1}\end{array}$ \\
\hline Total & 38 & 48198.2 & 71.8 & 194.5 & 2.0 & 34.0 & $48.5^{* *}$ \\
\hline Genotypes & 12 & $49045.9^{*}$ & $25.4^{*}$ & $273.9^{* *}$ & 3.2 & $35.4^{* *}$ & $21.4^{* *}$ \\
\hline ENV & 2 & $507452.1^{*}$ & $1008.4^{* *}$ & $1221.2^{* *}$ & 1.7 & $145.1^{* *}$ & $21.4^{* *}$ \\
\hline $\begin{array}{l}\text { Environment } \\
(\text { Gen } \times \text { Env) } \\
\text { Environment }\end{array}$ & 26 & $47806.9^{*}$ & $25 .^{* *}$ & $157.8^{* *}$ & 1.4 & $33.4^{* *}$ & $61.1^{* *}$ \\
\hline $\begin{array}{l}\text { Linear } \\
\text { Gen. × Env }\end{array}$ & 1 & $1014905.6^{*}$ & $17^{* *}$ & $2442.0^{* *}$ & 3.4 & $290.3^{* *}$ & $1218.5^{* *}$ \\
\hline Linear & 12 & $17107.5^{*}$ & $25.1^{* *}$ & $122.7^{* *}$ & 0.3 & $44.7^{* * *}$ & $30.3^{* *}$ \\
\hline Pooled Deviation & 13 & $1752.6^{*}$ & $8.2^{*}$ & $14.5^{* *}$ & $2.3^{* *}$ & $3.2^{* *}$ & 0.1 \\
\hline Pooled error & 13 & 878.4 & 8.2 & 0.2 & 0.1 & 0.1 & 6.8 \\
\hline
\end{tabular}




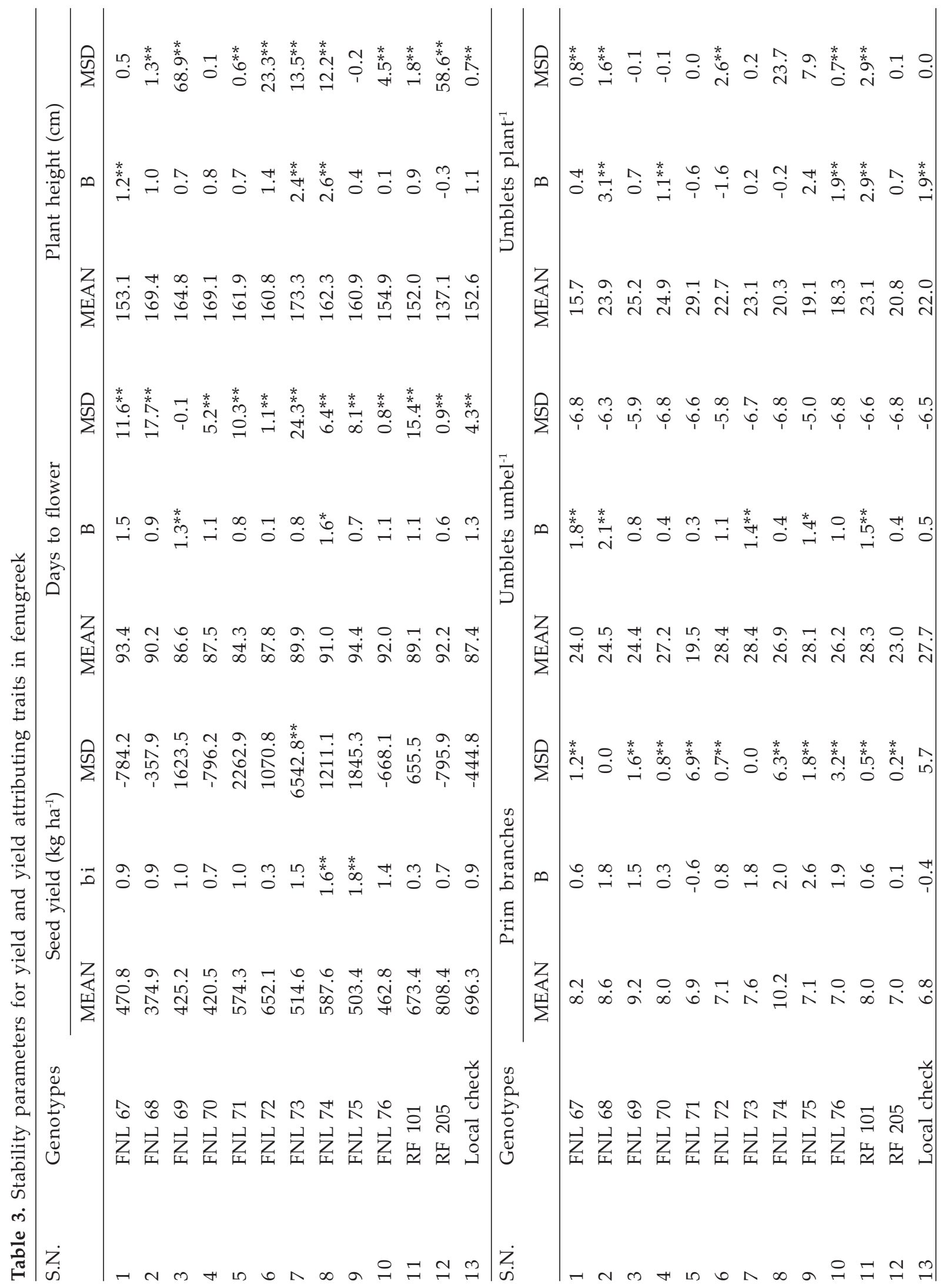


Table 4. Two way table showing stable and unstable genotypes for seed yield verses component characters

\begin{tabular}{|c|c|c|c|c|c|c|}
\hline \multirow{2}{*}{$\begin{array}{l}\text { Genotype } \\
\text { no }\end{array}$} & \multirow{2}{*}{$\begin{array}{l}\text { Stable } \\
\text { genotypes }\end{array}$} & \multicolumn{4}{|c|}{ Stability parameters (bi/S2di) of yield components } & \multirow[b]{2}{*}{$\begin{array}{l}\text { Umblets } \\
\text { umbel }^{-1}\end{array}$} \\
\hline & & $\begin{array}{l}\text { Days to } \\
\text { flower }\end{array}$ & $\begin{array}{l}\text { Plant } \\
\text { height }\end{array}$ & $\begin{array}{c}\text { Primary } \\
\text { bran plant }\end{array}$ & $\begin{array}{l}\text { Umbels } \\
\text { plant }^{-1}\end{array}$ & \\
\hline 12 & RF 205 (C) & S/S & $S / *$ & $\mathrm{~S} / \mathrm{S}$ & $\mathrm{S} / \mathrm{S}$ & S/S \\
\hline 13 & Local fennel (C) & $S / *$ & $S / S$ & $S / *$ & $\mathrm{~S} / \mathrm{S}$ & S/S \\
\hline
\end{tabular}

Where, $\mathrm{S}=$ stable genotypes; $\mathrm{S} / *, * / \mathrm{S}$ and ${ }^{*} / *$ unstable genotype; bi=regression coefficient; S2di=deviation from regression line; ${ }^{*}$ bi $\# 1$, S2di \#0

Based on stability parameters genotypes RF 205 and Local fennel were classified as stable for seed yield plant ${ }^{-1}$, which had their mean seed yield greater than the average of all the genotypes with unit regression coefficient (bi $=1$ ) and non-significant deviation from regression $\left(\mathrm{S}^{2} \mathrm{di}=0\right)$. This indicated their high stability over all the environments during 201213 to 2014-15. Lal (2008) and Verma \& Solanki

(2015) reported above average stability of Fennel genotypes for seed yield. The genotypes RF 101, FNL 72 and FNL 71 had above average mean, seed yield, regression coefficient of bi $=1$ but non-significant deviation from regression line $\left(S^{2} \mathrm{di}=0\right)$. Hence, indicating its specific adaptability under good agronomic management practices.

Table 5. Superiority of fennel genotypes for yield over checks during 2012-13 to 2014-15

\begin{tabular}{|c|c|c|c|c|c|}
\hline \multirow{3}{*}{ E.N. } & \multirow{3}{*}{ E.name } & \multicolumn{3}{|c|}{$2012-13$} & \\
\hline & & Yield $\left(\mathrm{kg} \mathrm{ha}^{-1}\right)$ & $\%$ superiority & Disease reaction & \\
\hline & & & RF 101(NC) & Local check & \\
\hline 6 & FNL 67 & 578.1 & $\mathrm{NO}$ & 2.75 & MR \\
\hline 11 & RF 101 (c) & 599.7 & $\mathrm{NO}$ & & MR \\
\hline 12 & RF205 (c) & 690.2 & $\mathrm{NO}$ & & MR \\
\hline \multirow[t]{2}{*}{13} & FNL (LC) & 562.6 & $\mathrm{NO}$ & & MR \\
\hline & & & $2013-14$ & & \\
\hline 6 & FNL 67 & & $\mathrm{NO}$ & 6.36 & MR \\
\hline 11 & RF 101 (c) & 686.9 & $\mathrm{NO}$ & & MR \\
\hline 12 & RF205 (c) & 777.1 & $\mathrm{NO}$ & & MR \\
\hline \multirow[t]{2}{*}{13} & FNL (LC) & 630.3 & $\mathrm{NO}$ & & MR \\
\hline & & & 2014-15 & & \\
\hline 1 & FNL 74 & 918.4 & 25.2 & 2.5 & MR \\
\hline 4 & FNL 75 & 914.9 & 24.7 & 2.1 & MR \\
\hline 20 & FNL 73 & 872.0 & 18.9 & -2.7 & MR \\
\hline 3 & FNL 71 & 807.3 & 10.0 & -9.9 & MR \\
\hline \multirow[t]{4}{*}{4} & FNL 76 & 770.4 & 5.0 & -14.0 & \\
\hline & RF 205 & 957.9 & 30.6 & 6.9 & \\
\hline & Local check & 896.2 & 22.2 & 0.0 & \\
\hline & RF 101 & 733.6 & 0.0 & & \\
\hline
\end{tabular}

Where, No=No superiority; NC=National check 
For the present study the meterological parameters recorded with Indian meterological standard week of 31 for first week of sowing, 37 for vegetative stage, 43 for flowering stage and 49 for physiological maturity stage respectively for 2012-13 to 2014-15 (Table 6). It was observed that during sowing period average optimum temperature of $27.6^{\circ} \mathrm{C}+$ $21.2^{\circ} \mathrm{C}$ were present over all the three years. At the same time average maximum humidity of $88.2 \%$ with minimum of $66.9 \%$ were recorded during first week of sowing. During vegetative stage of fennel crop mean maximum temperature of $24.9^{\circ} \mathrm{C}$ and minimum temperature of $15.2^{\circ} \mathrm{C}$ with humidity range of
$87.2 \%$ to $60.7 \%$ recorded. At flowering time consistent maximum minimum temperature of $24.9^{\circ} \mathrm{C}-15.2^{\circ} \mathrm{C}$ respectively registered with average humidiy of $89.2 \%$ to $38.4 \%$ present. At physiological maturity mean maximumminimum temperature of $32.0^{\circ} \mathrm{C}-15.0^{\circ} \mathrm{C}$ were registered while maximum humidity of $81.8 \%$ and minimum temperature of $37.3 \%$ were recorded. It was observed that at all the three years no rainfall during throughout the crop period.

The genotype FNL 67 had recorded 2.75 and 6.36 percent superiority for seed yield over local check during 2012-13 and 2013-14 respectively.

Table 6. Meterological parameters during crop growth period from 2012-13 to 2014-15

\begin{tabular}{|c|c|c|c|c|c|}
\hline \multirow[t]{3}{*}{ Year } & & \multirow{2}{*}{$\begin{array}{c}\text { Temperature } \\
\left({ }^{\circ} \mathrm{C}\right)\end{array}$} & \multicolumn{2}{|c|}{ Humidity } & \multirow{3}{*}{$\begin{array}{l}\text { Rain } \\
\text { fall } \\
(\mathrm{MM})\end{array}$} \\
\hline & \multirow[b]{2}{*}{ Max } & & \multicolumn{2}{|c|}{$(\%)$} & \\
\hline & & Min & Max & Min & \\
\hline & & \multicolumn{3}{|c|}{ Seed germination week } & \\
\hline $2012-13$ & 27.85 & 18.57 & 90.71 & 61.14 & Nil \\
\hline 2013-14 & 27.86 & 23.86 & 86 & 71.28 & Nil \\
\hline 2014-15 & 27 & 21.28 & 88 & 68.14 & Nil \\
\hline \multirow[t]{2}{*}{ Average } & 27.6 & 21.2 & 88.2 & 66.9 & \\
\hline & & \multicolumn{3}{|c|}{ Vegetative stage } & \\
\hline $2012-13$ & 25.14 & 16.28 & 90.71 & 64.14 & Nil \\
\hline 2013-14 & 24.29 & 13 & 80.28 & 53.71 & Nil \\
\hline 2014-15 & 25.14 & 16.25 & 90.71 & 64.14 & Nil \\
\hline \multirow[t]{2}{*}{ Average } & 24.9 & 15.2 & 87.2 & 60.7 & \\
\hline & & \multicolumn{3}{|c|}{ Flowering stage } & \\
\hline $2012-13$ & 25.42 & 11.42 & 88.71 & 29 & Nil \\
\hline 2013-14 & 25.71 & 15.42 & 89.57 & 57.28 & Nil \\
\hline 2014-15 & 25.42 & 11.42 & 88.71 & 29 & Nil \\
\hline \multirow[t]{2}{*}{ Average } & 25.5 & 12.8 & 89.0 & 38.4 & \\
\hline & & \multicolumn{3}{|c|}{ Physiological maturity } & \\
\hline $2012-13$ & 32.71 & 14.71 & 83 & 32.71 & Nil \\
\hline 2013-14 & 26.14 & 13.43 & 81.57 & 55.14 & Nil \\
\hline 2014-15 & 37.14 & 16.71 & 80.71 & 24 & Nil \\
\hline Average & 32.0 & 15.0 & 81.8 & 37.3 & \\
\hline
\end{tabular}


During 2014-15 five genotypes FNL 74, FNL 75, FNL 73, FNL 71, and FNL 76 recorded high heterosis for seed yield over RF 205 and RF 101, whereas FNL 74 \& FNL 75 registered positive heterosis over local check.

It was observed that national check (RF 205) showed wider stability for seed yield, days to flower, primary branches plant ${ }^{-1}$, umbels plant $^{-1}$ and umbelets umbel ${ }^{-1}$ while local fennel had wider stability for seed yield $\left(\mathrm{kg} \mathrm{ha}^{-1}\right)$, plant height, umbels plant ${ }^{-1}$ and umbelets umbel ${ }^{-1}$. While none of the test entries showed superior stable performance over the national and local checks during all the three years. This appears to be evidence for much greater genotype $x$ environment interaction for the entries to be evaluated than for the pure lines. This is somewhat unexpected in view of the greater homeostasis in unfavorable environments usually found in heterozygous genotypes. This needs further study.

\section{Acknowledgements}

Authors are thankful to Project Coordinator of AICRP on Spies, Kozhikode for support and constant encouragement. Authors are also thankful to Directorate of Research, Indira Gandhi Krishi Vishwavidyalaya (IGKV) for providing facility for conducting trial successfully.

\section{References}

Annual Report 2014 Department of Agriculture And Cooperation, Ministry of Agriculture Government of India, Krishi Bhawan, New Delhi, March, 2015 pp.28-29.

Eberhart SA \& Russell WA 1966 Stability parameters for comparing varieties. Crop Sci. 2: 357-361.

Lal RK 2008 Stability and genotype $\mathrm{x}$ environment interaction in Fennel. J. Herbs, Spices Med. Plants 13: 47-54.

Ramanujam S, Joshi BS, \& Saxena M B L 1964 Extent and randomness of cross-pollination in some umbelliferous spices of India. Indian J. Gen. 24: 62-67.

Ramanujam S \& Tewari V P 1970 Heterosis breeding in Fennel. Indian J. Gen. Plant Br. 30: 732-737.

Venkateswarlu O 1998 Phenotypic stability for grain yield in pigeonpea. Int. J. Chickpea Pigeonpea Newslett. 5: 41-42.

Lal R K 2014 Stability and genotype × environment Interaction in fennel. J. Herbs Spices Med. Plants 13: 47-54.

Verma P \& Solanki RK 2015 Stability of seed yield and its component traits in fennel Foeniculum vulgare). Indian J. Agril. Sci. 85: 1504-1507.

Drazic S, Zinanovic T \& Prodanovic S 2014 Stability of productive traits of genotypes of cultivated medicinal plants of family Apiaceae. Biotechnol. Biotechnol. Equipments 21: 100-106. 
Effect of irrigation methods and mulching on growth and yield parameters of chilli (Capsicum annum L.) in arid condition

\author{
R L Bhardwaj ${ }^{1}$, M M Sundria, S R Kumhar \& N Kumar \\ Agricultural Research Station, Agriculture University, Jodhpur-342 304, Rajasthan. \\ *E-mail: rajubhardwaj3@gmail.com
}

Received 20 May 2017; Revised 25 February 2018; Accepted 26 March 2018

\begin{abstract}
The research work was carried out to study the impact of various irrigation methods and mulching on plant growth, production and profitability of chilli cv. R.Ch. 1 at Agricultural Research Station, Mandor, Jodhpur during July, 2016 to February, 2017. The results of surface irrigation were compared with drip irrigation system under no mulch and in conjunction with plastic mulch. The results revealed that the crop was irrigated by drip irrigation on raise bed with 100 micron Linear Low Density Poly Ethylene plastic mulch ( $\mathrm{T}_{8}$ treatment) exhibited significantly higher seedling survival at 15 and 30 days after transplanting (95.16\% and 91.70\%), highest plant height $\left(47.10 \mathrm{~cm}\right.$ at 45 DAT and $54.60 \mathrm{~cm}$ at harvest), highest number of branches (14.93) plant ${ }^{-1}$, maximum stem girth $(2.32 \mathrm{~cm})$ number of roots plant ${ }^{-1}(138.5)$, highest fruit set $(38.47 \%)$, length of fresh fruit $(12.56 \mathrm{~cm})$, diameter of fruit $(3.52 \mathrm{~cm})$ and fresh weight of fruit ${ }^{-1}(8.42 \mathrm{~g})$ was observed. The maximum number of fruits plant ${ }^{-1}(125)$, highest yield plant ${ }^{-1}(1052.5 \mathrm{~g})$, yield ha ${ }^{-1}(337.63 q)$ and premier fruit quality score (9.11) with maximum net return (Rs.326407.28) and benefit: cost ratio (3.41) was also reported in same treatment. Comparatively minimum time (15 hours) required for one hectare irrigation was also reported in drip irrigation on raise bed with plastic mulch.

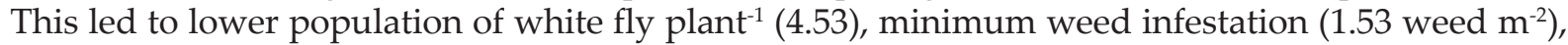
leaf curl $(5.50 \%)$ and fruit rot $(5.0 \%)$ incidence than other treatment combinations. The minimum growth, yield and profitability were reported in check basin method of irrigation without mulch ( $\mathrm{T}_{1}$ treatment).
\end{abstract}

Keywords: Capsicum annum, Day After Transplanting, leaf curl, surface irrigation, survival

Chilli (Capsicum annuum L.) is an important commercial vegetable cum spice crop of India belongs to the family Solanaceae. The production of chilli crop is affected adversely by moisture deficit. Productivity of the crop can be increased by adopting improved package of practices, particularly in-situ moisture conservation by mulching as well as high-tech irrigation especially drip irrigation with appropriate irrigation scheduling. Use of soil cover and mulching is also known to be beneficial chiefly through their influence on soil moisture conservation, solarization and control of weeds. Beneficial response of plants 
to mulch includes early production, more yield and reduced insect and disease problems (Pattanaik et al. 2003). Linear Low Density Poly Ethylene (LLDPE) plastic films have been proved as better mulch because of their puncture resistance quality, thinness and lower cost (Panda 2004). Numerous experiments have reported the benefits of LLDPE mulch in several crops, but research is limited on response of chilli production in western Rajasthan by this method. Keeping this in background, the present study was undertaken to study the effect of different irrigation methods and mulching on chilli crop and compare the result with the conventional method of growing the crop under surface irrigation without mulch.

A field experiment was conducted at Agricultural Research Station, Mandor, Jodhpur (Rajasthan), India during kharif seasons of year 2016-17. The soil of experimental plot was of sandy loam texture with average $\mathrm{pH}$ range 8.5 , having organic carbon $0.55 \%$, available N $180 \mathrm{~kg} \mathrm{ha}^{-1}$, P $27.5 \mathrm{~kg} \mathrm{ha}^{-1}$ and $\mathrm{K}$ $250.0 \mathrm{~kg} \mathrm{ha}^{-1}$ during experimentation. The experiment was conducted in a completely randomized design having nine treatments comprising by different irrigation methods and mulching viz., $\mathrm{T}_{1}=$ Check basin method, $\mathrm{T}_{2}=$ furrow irrigation method, $\mathrm{T}_{3}=$ Raise bed with trench method, $\mathrm{T}_{4}=$ Flat bed with drip irrigation, $\mathrm{T}_{5}=$ Flat bed + plastic mulch + drip irrigation, $\mathrm{T}_{6}=$ Raise bed with drip irrigation, $\mathrm{T}_{7}=$ Raise bed + organic mulch + drip irrigation, $\mathrm{T}_{8}=$ Raise bed + plastic mulch + drip irrigation, $\mathrm{T}_{9}=$ Sprinkler irrigation method. In well prepared field, transplanting of Chilli seedlings variety RCh 1 of 35-40 days old were planted in pair row method with a spacing of $45 \mathrm{~cm} x$ $45 \mathrm{~cm} / 90 \mathrm{~cm}\left(33,333\right.$ plant ha $\left.{ }^{-1}\right)$ during last week of June. In check basin and sprinkler system of irrigation the bed size is $2 \times 2$ meter and in all other methods is $1 \times 4$ meters. The cultural practices of the crop were followed as per the recommendations. The organic material and LLDPE silver colour film of 100-micron thickness was used for mulching around the plant. The lateral lines of $12 \mathrm{~mm}$ diameter LLDPE pipes were laid along with crop rows.
The laterals were provided with inlet drippers of 8 litre $\mathrm{hr}^{-1}$ discharge capacity. All the observations were taken from five randomly selected plant of each replication throughout the investigation period at appropriate time by adopting standard method for growth, development, fruiting behavior and yield.

Seedling survival per cent (after transplanting in main field at 15 DAT and 30 DAT) was recorded by following formula;

Survival percent $=[$ Total survival transplanted plants / Total transplanted plants] $\times 100$

Plant height (at 45 DAT and at harvesting) was measured from soil surface upto the highest shoot tip by straightening all branches. Stem girth was measured $1 \mathrm{~cm}$ from the base of the stem using vernier calliper. Observation of number of branches, days taken to first flower initiation, duration of fruiting period and number of fruit plant ${ }^{-1}$ was recorded by standard counting method. Number of roots, root length was measured by destructive method of uprooting the plants and taking measurement by standard method. Length of fresh fruits measured by scale and fruit diameter using vernier calliper and expressed in centimeter. Fruit set per cent was recorded by following formula;

Fruit set per cent $=[$ Total number of fruit set plant $^{-1} /$ Total number of flowers plant $\left.{ }^{-1}\right] \times 100$

Fruit weight was determined by weighing method at the time of harvesting and expressed in gram fruit ${ }^{-1}$. The total fruit yield plant ${ }^{-1}$ and hectare $^{-1}$ was calculated by weighing total marketable fruits and has been expressed in gram and quiantal respectively. Further, the net return was calculated by subtracting cost of each treatment from gross return. The gross return was calculated from yield multiplied by average market rate during the period of investigation. The benefit cost ratio was calculated by dividing net return to total cost of cultivation. Benefit-Cost ratio and net profit were carried out to determine the economic feasibility of the crop using surface and drip irrigation as suggested by Tiwari et al. (1998a). 
The seasonal system cost of drip irrigation system included depreciation, prevailing bank interest rate, and repair and maintenance cost of the system. The fixed cost of drip irrigation system was determined to be Rs 112,000 ha-1. The useful life of drip system was considered to be 10 years. The system cost was evaluated by distributing the fixed cost of system over life period of drip irrigation set. For calculating depreciation, the life of the drip irrigation set and $10 \%$ junk value was considered. The interest was calculated on the average of investment of the drip irrigation set taking into consideration the value of the set in the first and last year @10\% per annum. Cost of repairs and maintenance of set is @2\% of initial cost of the drip irrigation set per year. The cost of cultivation includes expenses incurred in land preparation, interculture operation, fertilizer, crop protection measures, irrigation water and harvesting with labour charges. Therefore, total seasonal cost was worked as: depreciation, interest, repairs and maintenance cost of set + cost of cultivation + cost of mulch. The income from produce was calculated using prevailing average market price of capsicum @ Rs $1250 \mathrm{q}^{-1}$. Disease incidence (leaf curl and fruit rot) and quality of fruits was measured by visual inspection (Five member team of crop experts and plant pathologist). White fly population plant $^{-1}$ and weed infestation meter ${ }^{-2}$ was calculate by simple counting method. The time required for irrigation was calculated as per actual required time of irrigation of specified area by different methods of irrigation. To test the significance of variance of data obtained from crop growth, yield and economics of variance technique for completely randomized design was done by standard procedure prescribed by Panse \& Sukhatme (1985). Significance of difference among the treatments effect was tested by ' $\mathrm{F}$ ' test and critical difference (CD) was calculated, wherever the results were significant.

The results revealed that, the irrigation methods and mulching are significantly influenced growth attributes at all the growth stages (Table 1). The maximum seedling survival per cent at 15 DAT (95.10\%) and 30 DAT (91.70\%) was recorded in $\mathrm{T}_{8}$ treatment, which was significantly superior to other treatment but at par with $\mathrm{T}_{6}$, and $\mathrm{T}_{7}$ treatments. The maximum survival per cent of seedling in $\mathrm{T}_{8}$ treatment might be due to more favourable moisture condition for seedling transplanting and reestablishment of roots than others. The height of plant under treatment T8 $(47.10 \mathrm{~cm}$ at 45 DAT) and treatment T6 $(62.60 \mathrm{~cm}$ at harvest $)$ was found highest among all other treatments and is $67.19 \%$ and $13.40 \%$ higher than the $\mathrm{T}_{1}$ treatment. About to number of branch plant ${ }^{-1}$, maximum value was recorded in treatment T8 (14.93) followed by treatment T7 (12.53) and the lowest value was in treatment T1 (7.17). Maximum stem girth at harvest $(2.36 \mathrm{~cm})$ and highest number of roots plant ${ }^{-1}$ (138.50) were observed in $\mathrm{T}_{8}$ treatment whereas longest root system $(10.50 \mathrm{~cm})$ was observed in $\mathrm{T}_{3}$ treatment. The minimum stem girth $(1.68 \mathrm{~cm})$ and the number of roots plant ${ }^{-1}$ (53.57) were observed in $\mathrm{T}_{1}$ treatment whereas shortest root system $(7.97 \mathrm{~cm})$ was observed in $\mathrm{T}_{9}$ treatment. The higher available moisture status in soil favourably influences the uptake of nutrients which maintains the cell turgidity, cell elongation, photosynthesis and respiration at optimum level, leading to favourable growth and development of plant in terms of plant height, number of branches plant ${ }^{-1}$, stem girth and number of root plant $t^{-1}$ in the present study. The highest increase in vegetative growth in drip irrigation with mulching might be due to the availability of soil moisture as well as favourable temperature at optimum level for plant growth development (Pattanaik et al. 2003; Paul et. al. 2013). The lowest value of vegetative growth in $\mathrm{T} 1 \mathrm{might}$ be because of unfavourable moisture regime (moisture stress or excess moisture) in the soil through surface irrigation and competition of weeds for nutrients (Pattanaik et al. 2003; Agrawal \& Agrawal 2005). The increased growth attributes might have supplied water and nutrients in adequate proportion, which resulted in triggering the production of plant growth hormone, viz., indole acetic acid (IAA) and 
Table 1. Effect of different irrigation methods and mulching on vegetative parameter of chilli

\begin{tabular}{|c|c|c|c|c|c|c|c|c|}
\hline \multirow[t]{2}{*}{ Treatments } & \multicolumn{2}{|c|}{$\begin{array}{l}\text { Seedling } \\
\text { survival } \\
\%\end{array}$} & \multicolumn{2}{|c|}{$\begin{array}{l}\text { Plant } \\
\text { height } \\
(\mathrm{cm})\end{array}$} & \multirow{2}{*}{$\begin{array}{l}\text { Average } \\
\text { number of } \\
\text { branches } \\
\text { plant }^{-1}\end{array}$} & \multirow[t]{2}{*}{$\begin{array}{l}\text { Stem girth } \\
\text { at harvest } \\
(\mathrm{cm})\end{array}$} & \multirow[t]{2}{*}{$\begin{array}{l}\text { Length } \\
\text { of root } \\
(\mathrm{cm})\end{array}$} & \multirow[t]{2}{*}{$\begin{array}{l}\text { No. of } \\
\text { roots plant } \\
\text { plant }^{-1}\end{array}$} \\
\hline & 15 DAT & 30 DAT & $45 \mathrm{DAT}$ & $\begin{array}{c}\text { At } \\
\text { harvest }\end{array}$ & & & & \\
\hline $\mathrm{T}_{1}$ & 78.17 & 73.93 & 28.17 & 55.20 & 7.17 & 1.68 & 9.50 & 53.57 \\
\hline $\mathrm{T}_{2}$ & 82.37 & 79.23 & 29.07 & 57.30 & 8.07 & 1.86 & 10.00 & 69.77 \\
\hline $\mathrm{T}_{3}$ & 86.97 & 83.83 & 32.07 & 61.70 & 8.27 & 1.88 & 10.50 & 78.37 \\
\hline $\mathrm{T}_{4}$ & 88.40 & 84.73 & 34.03 & 61.55 & 9.48 & 2.26 & 8.53 & 102.50 \\
\hline $\mathrm{T}_{5}$ & 90.10 & 86.33 & 38.53 & 61.70 & 10.28 & 2.33 & 8.03 & 108.70 \\
\hline $\mathrm{T}_{6}$ & 92.50 & 89.33 & 40.43 & 62.60 & 9.98 & 2.32 & 9.03 & 119.00 \\
\hline $\mathrm{T}_{7}$ & 93.40 & 90.90 & 41.97 & 53.20 & 12.53 & 2.30 & 8.97 & 135.70 \\
\hline $\mathrm{T}_{8}$ & 95.10 & 91.70 & 47.10 & 54.60 & 14.93 & 2.36 & 8.47 & 138.50 \\
\hline $\mathrm{T}_{9}$ & 85.20 & 80.10 & 34.90 & 56.70 & 9.73 & 2.00 & 7.97 & 110.10 \\
\hline S.Em. + & 1.646 & 1.539 & 2.173 & 1.859 & 0.442 & 0.088 & 0.228 & 1.300 \\
\hline $\mathrm{CD}(\mathrm{P}<0.05)$ & 4.871 & 4.556 & 6.432 & 5.504 & 1.327 & 0.260 & 0.675 & 3.848 \\
\hline
\end{tabular}

higher number of leaves and roots throughout the cropping period (Sankar et al. 2008).

The drip irrigation in combination with mulch significantly increased the yield of chilli as compared to drip irrigation without mulch (Table 2) and surface irrigation methods. The minimum days (42.38) required for first flower initiation was reported in $\mathrm{T}_{9}$ treatment whereas the maximum days (51.39) was required in $\mathrm{T}_{5}$ treatment. Among various treatments, highest fruit set $(38.47 \%)$, length of fresh fruit $(12.56$ $\mathrm{cm})$, diameter of fruit $(3.52 \mathrm{~cm})$, duration of fruiting (71.38 days), fresh weight of fruit ${ }^{-1}$ (8.42 g), maximum number of fruits plant ${ }^{-1}(125)$, highest yield plant ${ }^{-1}(1052.5 \mathrm{~g})$ and yield ha-1 (337.63 q) was recorded under $\mathrm{T}_{8}$ treatment, whereas lowest yield (153.45 q ha $\left.{ }^{-1}\right)$ was recorded under $T_{1}$ treatment. This might be due to water stress during the critical growth period and fruit development stage coupled with aeration problem in first few days immediately after irrigation. Another reason to get low yield by surface irrigation without mulch might be due to less availability of nutrients for crop growth due to leaching and high weed competition between the crops (Pattanaik et al. 2003). In drip irrigation system on raise bed with plastic mulch the water is applied at a low rate for a longer period at frequent intervals near the plant root zone through lower pressure delivery system, which increases the availability of nutrients near the root zone with a reduction in leaching losses and minimum weed competition. More nutrient availability, especially near the root zone might have increased the translocation of photosynthetes to storage organ of chilli resulting in an increased weight of fruits. This result corroborated the findings of Singh (2007), Sankar et al. (2008), Paul et al. (2013) and Kumar et al. (2016).

Irrigation methods and mulching also significantly influenced the gross return, net return and benefit cost ratio in chill (Table 3). Maximum net profit of Rs. 326407.28 ha $^{-1}$ with $\mathrm{B}$ : C ratio of 3.41 was recorded in $\mathrm{T}_{8}$ treatment followed by Rs 296192.61 ha $^{-1}$ with B: C ratio of 3.11 in $\mathrm{T}_{5}$ treatment and lowest net profit of Rs 119007.80 ha $^{-1}$ with a B: C ratio of 1.63 in $T_{1}$ treatment (Table 3). It is observed that, the drip 
Table 2. Effect of different irrigation methods and mulching on yield and yield attributes of chilli

\begin{tabular}{lccccccccc}
\hline Treatments & $\begin{array}{c}\text { First } \\
\text { flower } \\
\text { initiation } \\
\text { (DAT) }\end{array}$ & $\begin{array}{c}\text { Fruit } \\
\text { set } \\
\%\end{array}$ & $\begin{array}{c}\text { Length } \\
\text { of fresh } \\
\text { fruit } \\
\text { (cm) }\end{array}$ & $\begin{array}{c}\text { DiameterDuration } \\
\text { of fresh } \\
\text { fruit } \\
\text { (cm) }\end{array}$ & $\begin{array}{c}\text { Weight } \\
\text { fruiting } \\
\text { (days) }\end{array}$ & $\begin{array}{c}\text { of single } \\
\text { fresh } \\
\text { fruit } \\
(\mathrm{gm})\end{array}$ & $\begin{array}{c}\text { No. of } \\
\text { fruits } \\
\text { plant }\end{array}$ & $\begin{array}{c}\text { Yield } \\
\text { plant }^{-1} \\
(\mathrm{gm})\end{array}$ & $\begin{array}{c}\text { Yield } \\
\text { ha }^{-1} \\
(\mathrm{q})\end{array}$ \\
\hline $\mathrm{T}_{1}$ & 45.70 & 17.23 & 10.75 & 2.87 & 52.70 & 7.63 & 60.33 & 460.34 & 153.45 \\
$\mathrm{~T}_{2}$ & 47.70 & 17.01 & 11.30 & 2.75 & 54.00 & 7.79 & 65.33 & 508.95 & 169.65 \\
$\mathrm{~T}_{3}$ & 47.40 & 21.31 & 11.35 & 2.78 & 56.10 & 7.82 & 68.33 & 534.37 & 178.12 \\
$\mathrm{~T}_{4}$ & 49.19 & 27.00 & 12.01 & 3.01 & 62.39 & 7.97 & 74.17 & 591.11 & 197.03 \\
$\mathrm{~T}_{5}$ & 51.39 & 31.81 & 12.19 & 3.14 & 68.59 & 8.23 & 114.17 & 939.59 & 313.19 \\
$\mathrm{~T}_{6}$ & 49.99 & 30.89 & 12.39 & 3.22 & 60.39 & 8.26 & 89.17 & 736.52 & 245.50 \\
$\mathrm{~T}_{7}$ & 46.58 & 36.74 & 12.30 & 3.28 & 66.38 & 8.36 & 95.00 & 794.20 & 251.53 \\
$\mathrm{~T}_{8}$ & 48.38 & 38.47 & 12.56 & 3.52 & 71.38 & 8.42 & 125.00 & 1052.50 & 337.63 \\
$\mathrm{~T}_{9}$ & 42.38 & 16.27 & 11.57 & 3.10 & 47.58 & 7.90 & 75.00 & 592.50 & 184.30 \\
$\mathrm{~S} . \mathrm{Em} .+$ & 1.247 & 1.570 & 0.201 & 0.059 & 1.247 & 0.133 & 1.302 & 9.913 & 8.257 \\
$\mathrm{CD}(\mathrm{P}<0.05)$ & 3.693 & 4.649 & 0.595 & 0.176 & 3.693 & 0.395 & 3.854 & 29.337 & 24.437 \\
\hline
\end{tabular}

irrigation with mulched treatments $\mathrm{T}_{5}, \mathrm{~T}_{7}$ and $\mathrm{T}_{8}$ gave better net return with higher $\mathrm{B}$ : $\mathrm{C}$ ratio $\mathrm{ha}^{-1}$ than their corresponding treatments without mulching in conventional irrigation method. The highest net return (US\$ $7098 \mathrm{ha}^{-1}$ ), incremental net return (US\$ $1556 \mathrm{ha}^{-1}$ ), and incremental benefit-cost ratio (7.03) were found for $50 \%$ water application with straw mulch (Biswas et al. 2015). The results are in conformity with the findings of Singh (2007), Sankar et al. (2008) and Kumar et al. (2016). Apart from reducing water consumption, drip irrigation with mulching also helps in reducing cost of cultivation and improving productivity of crops as compared to the same crops cultivated under flood method of irrigation (Paul et al. 2013).

Irrigation time significantly pretentious by different irrigation methods. The minimum time required in irrigation ( 14.50 hours) in $T_{5}$ treatment which closely followed by $\mathrm{T}_{8}$ treatment. Drip irrigation method with or without mulching required less irrigation time than without mulching in conventional irrigation method. There was significant effect of LLDPE mulch over drip irrigation system alone. Drip irrigation with LLDPE mulching $\left(\mathrm{T}_{5} \& \mathrm{~T}_{8}\right.$ treatment) saving irrigation time (21.40 hour ha ${ }^{-1}$ and 21.35 hour ha-1) upto 60 per cent by reducing water losses and increased irrigation efficiency. The increase in water saving per cent in trench method $\left(\mathrm{T}_{2}\right)$, drip irrigation system alone $\left(\mathrm{T}_{4}\right)$, drip irrigation system with LLDPE mulch $\left(\mathrm{T}_{5} \& \mathrm{~T}_{8}\right)$, drip irrigation with organic mulch $\left(\mathrm{T}_{7}\right)$ and sprinkler system $\left(\mathrm{T}_{q}\right)$ over conventional surface irrigation by check basin method $\left(\mathrm{T}_{1}\right)$ was $38.8 \%, 46.6 \%, 60.0 \%, 54.4 \%$ and $41.9 \%$ respectively. The highest water use efficiency of $592 \mathrm{~kg} \mathrm{ha}^{-1} \mathrm{~mm}^{-1}$ was obtained with 50 per cent water application under polyethylene mulch (Biswas et al. 2015). Drip irrigation with mulching helps to achieve yield gains of upto 100 per cent, water savings of upto $40-80$ per cent, and associated fertilizer, pesticide, and labour savings over conventional irrigation systems in capsicum crop (Paul et al. 2013). Similar trend has been reported in water use efficiency for okra crop by Tiwari et al. (1998a) and for tomato crop by Singh (2007). 
Table 3. Effect of different irrigation methods and mulching on economics, fruit quality, water saving $(\%)$, insect-pest and weed infestation of chilli

\begin{tabular}{lcccccccc}
\hline $\begin{array}{l}\text { Treat- } \\
\text { ments }\end{array}$ & $\begin{array}{c}\text { Net } \\
\text { Return }\end{array}$ & $\begin{array}{c}\text { B:C } \\
\text { ratio }\end{array}$ & $\begin{array}{c}\text { Quality } \\
\text { score of } \\
\text { fruits }\end{array}$ & $\begin{array}{c}\text { Water } \\
\text { saving (\%) } \\
\text { time (h) } \\
\text { for ha }{ }^{-1} \\
\text { irrigation }\end{array}$ & $\begin{array}{c}\text { No. of } \\
\text { white fly } \\
\text { plant }\end{array}$ & $\begin{array}{c}\text { Fruit } \\
\text { Rot } \\
(\%)\end{array}$ & $\begin{array}{c}\text { Leaf } \\
\text { curl } \\
(\%)\end{array}$ & $\begin{array}{c}\text { Weed } \\
\text { Infest- } \\
\text { ation }\end{array}$ \\
\hline $\mathrm{T}_{1}$ & 119007.80 & 1.63 & 7.24 & $36.30(0.0 \%)$ & 17.43 & 20.02 & 15.84 & 30.03 \\
$\mathrm{~T}_{2}$ & 135858.99 & 1.78 & 7.46 & $22.20(38.8 \%)$ & 13.73 & 18.02 & 12.34 & 17.43 \\
$\mathrm{~T}_{3}$ & 144550.55 & 1.85 & 8.04 & $22.45(38.2 \%)$ & 12.43 & 14.02 & 10.84 & 15.53 \\
$\mathrm{~T}_{4}$ & 170392.68 & 2.24 & 8.00 & $19.40(46.6 \%)$ & 11.60 & 10.82 & 9.50 & 12.40 \\
$\mathrm{~T}_{5}$ & 296192.61 & 3.11 & 8.50 & $14.50(60.0 \%)$ & 7.90 & 7.82 & 7.30 & 2.10 \\
$\mathrm{~T}_{6}$ & 225678.88 & 2.78 & 8.20 & $18.15(50.0 \%)$ & 10.40 & 8.82 & 8.60 & 10.10 \\
$\mathrm{~T}_{7}$ & 230913.36 & 2.77 & 8.50 & $16.55(54.4 \%)$ & 9.53 & 6.00 & 8.10 & 5.73 \\
$\mathrm{~T}_{8}$ & 326407.28 & 3.41 & 9.11 & $14.55(60.0 \%)$ & 4.53 & 5.00 & 5.50 & 1.53 \\
$\mathrm{~T}_{9}$ & 152772.53 & 1.97 & 6.50 & $21.10(41.9 \%)$ & 15.43 & 19.00 & 13.40 & 32.18 \\
$\mathrm{~S} . \mathrm{Em} .+$ & 0.001 & 0.005 & 0.162 & 1.247 & 0.346 & 0.568 & 0.227 & 0.394 \\
$\mathrm{CD}(\mathrm{P}<0.05)$ & 0.003 & 0.017 & 0.480 & 3.693 & 1.026 & 1.68 & 0.672 & 1.166 \\
\hline
\end{tabular}

Occurrence of chilli leaf curling and fruit rot was detected throughout the investigation period. The best performance, with a marked reduction in leaf curling and fruit rot and improve fruit quality was observed in drip irrigation with LLDPE mulching (Table 3). The minimum incidence of fruit rot $(5.0 \%)$, leaf curing $(5.5 \%)$ and highest quality score of fruit (9.11) was observed in $T_{8}$ treatment which was closely followed by $\mathrm{T}_{7}$ and $\mathrm{T}_{5}$ treatments where as maximum incidence of fruit rot $(20.02 \%)$ and leaf curling $(15.84 \%)$ was reported in check basin method of irrigation ( $T_{1}$ treatment) whereas minimum quality score (6.50) was observed in $\mathrm{T}_{9}$ treatment. Presence of white fly and weed was observed throughout the investigation period. The minimum population of white flies (4.53 plant $\left.^{-1}\right)$ and weed infestation (1.53 weed $\mathrm{m}^{-2}$ ) was observed in $\mathrm{T}_{8}$ treatment whereas highest incidence of white flies (17.43 plant ${ }^{-1}$ ) and weed infestation (30.03 weed $\mathrm{m}^{-2}$ ) was observed in $T_{1}$ treatment. This is due to the fact that in drip irrigation with mulching significantly reduced additional moisture level in field environment which in turn increase quality of fruits and reduce disease infestation, white fly population as well as it also trim down weed seed germination, growth and development. The increase in quality of fruits was due to the effective utilization of applied nutrients, water and significantly reduced weed growth; disease incidence and increased rate of photosynthesis, sink capacity and accumulated more amounts of dry matter and finally increased quality of fruits and yield. Conventional surface irrigation methods without mulching provide favorable environmental condition for increase insect population and development of disease as well as germinate and develop high density weed plants. The beneficial effect of drip irrigation and black LLDPE mulch in capsicum, tomato and okra was also reported earlier by Horo et al. (2003); Singh (2007); Vankar \& Shinde (2007), Bhardwaj \& Sarolia (2012), Paul et al. (2013).

The combination of raised bed + drip irrigation system with LLDPE mulching is observed to be economical and cost effective as compared with conventional surface irrigation without mulching. Thus, the use of drip irrigation system either alone or in combination with 
mulching, could increase the chilli yield quality of fruits and profitability. It also reduces white fly population, disease incidence (root rot and leaf curling) and minimise with crop weed competition. Drip irrigation with mulching increase water use efficiency by significant reduction in irrigation time ha ${ }^{-1}$. It is concluded that the drip irrigation method with LLDPE mulching is suitable for chilli production in arid and semi arid condition of western Rajasthan.

\section{References}

Agrawal N \& Agrawal S 2005 Effect of drip irrigation and mulches on the growth and yield of banana $c v$. Dwarf Cavendish. Indian J. Hort. 62: 238-240.

Biswas S K, Akanda A R, Rahman M S \& Hossain M A 2015 Effect of drip irrigation and mulching on yield, water-use efficiency and economics of tomato. Plant Soil Environ. 61: 97-102.

Bhardwaj R L \& Sarolia D K 2012 Effect of mulching on crop production under rainfed condition: A Review. Agri. Rev. 34: 188-197.

Horo P, Choudhary B M, Prasad B N \& Kandeyang S 2003 Effect of micro irrigation on growth and yield of tomato in Jharkhand. The Orissa J. Hort. 31: 80-83.

Kumar R, Himanshu Trivedi, Rahul Yadav, Bhagwan Das \& Ankur Singh Bist 2016 Effect of drip irrigation on yield and water use efficiency on Brinjal (Solanum melongena) cv. Pant samrat. Int. J. Engg. Sci. Res. Technol. 5: 7-17.

Panda S C 2004 Mulching. In: Panda S C, Patnaik K K, Mishra J N, Pradhan P C \& Alim M A (Eds.), Training Manual on Precision Farming in Horticulture. PFDC, OUAT, Bhubaneswar.

Panse V G \& Sukhatme P V 1985 Statistical Methods for Agricultural Workers. ICAR, New Delhi, pp.63-100.

Pattanaik S K, Sahu N N, Pradhan P C \& Mohanty M K 2003 Response of Banana to drip irrigation under different irrigation designs. J. Agri. Engg. ISAE 40: 29-34.

Paul J C, Mishra J N, Pradhan P L \& Panigrahi B 2013 Effect of drip and surface irrigation on yield, water use efficiency and economics of capsicum (Capsicum annum L.) grown under mulch and non-mulch conditions in eastern coastal India. European J. Sustainable Dev. 2: 99-108.

Sankar V, Lawande K E \& Tripathy P C 2008 Effect of micro irrigation on growth, yield and water-use-efficiency of onion (Allium cepa) under Western Maharashtra conditions. Indian J. Agri. Sci. 78: 584-588.

Tiwari K N, Mal P K, Singh R M \& Chattopadhya A 1998a Response of Okra to drip irrigation under mulch and non-mulch conditions. Agril. Water Manag. 38: 91-102. 


\title{
Evaluation of stable and non shattering isabgol cultivar - Gujarat isabgol 4
}

\author{
D G Patel, H B Patel*, P T Patel, H Patel \& A U Amin
}

Seed Spices Research Station, Sardarkrushinagar Dantiwada Agricultural University, Jagudan-382 710, Mahesana, Gujarat.

${ }^{*}$ E-mail: hirenpbg@yahoo.co.in

Received 02 November 2017; Revised 10 April 2018; Accepted 28 April 2018

\begin{abstract}
Isabgol growing area was surveyed during 2009-10 and selected genotypes were evaluated in preliminary evaluation trial (PET) during 2010-13 and in large scale varietal trial (LSVT) during 2013-15. It was found that JI-09-21 recorded better growth and yield characters and yield over check Gujarat Isabgol 3. The JI-09-21 did not shatter much even after water dripping and recommended for cultivation as Gujarat Isabgol 4.
\end{abstract}

Keywords: gujarat isabgol 4, isabgol, new variety, non shattering type

Isabgol (Plantago ovata Forsk) is a short duration, more remunerative and medicinally important crop of arid and semiarid regions. In India, it is largely grown in Gujarat, Rajasthan, Madhya Pradesh and Haryana. The area under Isabgol in India during 2014-15 is 1.09 lakh hectares. The production recorded 72 thousand MT with productivity of $660 \mathrm{~kg} \mathrm{ha}^{-1}$. In Gujarat, area mostly falls in Banaskantha, Kachchh and Patan districts with acreage of nine thousand hectare with production and productivity $5000 \mathrm{MT}$ and $556 \mathrm{~kg} \mathrm{ha}^{-1}$, respectively during 2015-16 (Anonymous 2016a). During the last decade, area and production of isabgol has decreased to the tune of $343 \%$ and $281 \%$, respectively, mainly due to problems of seed shattering. At the time of maturity, unseasonal rain or heavy dew leads to failure of the crop which is the fact for reduction of area under Isabgol (Anonymous 2016b). The objective of the study was to evolve non-shattering isabgol cultivars.
Isabgol growing area of Kachchh in Gujarat was surveyed during 2009-10 and subsequently genotypes were evaluated. First three years (2010-11 to 2012-13) 13 genotypes (JI-09-03, 07, $10,13,15,16,20,21,22,23,24,25$ and 26) with check (Gujarat Isabgol -03) were evaluated in preliminary evaluation - trial (PET). During 2013-14 and 2014-15, nine genotypes (JI-08-02, JI-09-07, 13, 16, 20, 21, 22, 24 and 25) along with check (Gujarat Isabgol -03) was tested. The trials were carried out at three different locations viz., Jagudan, Kholwada and Deesa in a randomized block design with three replications.

The stability analysis of variance and stability parameters viz., linear regression coefficient (bi) and deviation from regression $\left(\mathrm{S}^{2} \mathrm{di}\right)$ of genotype means over environment were computed as suggested by Eberhart \& Russell (1966).

Shattering per cent was computed as suggested by Singh et al. (2005) and Chandra (1967). Five 
plants in each replication were selected at maturity stage. Entire spike were dipped in water and then observed for seed shattering from selected plants. The percentage of seed shattering calculated by using a following formula.

Shattering per cent $=[($ Expected seed yield Seed wt. after threshing) / (Expected seed yield)] $\times 100$

Expected seed yield= H.I. x Sun Dry wt. (kg)/ 100

Considering eight trials at three locations for five years, JI-09-21 was recorded higher $(928 \mathrm{~kg}$ $\mathrm{ha}^{-1}$ ) seed yield against $830 \mathrm{~kg} \mathrm{ha}^{-1}$ of Gujarat Isabgol 3 (GI 3), which was $11.78 \%$ higher than GI-3 (Table 1). The new variety named as
Gujarat Isabgol 4 was having more tillers plant $^{-1}(6.0)$, more spikes plant ${ }^{-1}(22.7)$, seeds spike $^{-1}$ (80.7), higher test weight (1.58 gm) and high swelling factor $\left(11.4 \mathrm{cc} \mathrm{g}^{-1}\right)$ than that of check variety GI-3, due to these yield contributing traits GI-4 is having high seed yield potential (Table 3 ). The similar kind of results also obtained by Prajapati et al. (2011).

Gujarat Isabgol 4 recorded high mean with regression coefficient (bi) near unity and deviation from regression $\left(\mathrm{S}^{2} \mathrm{di}\right)$ around zero for seed yield, indicating GI-4 has average responsiveness and are highly stable over environments (Table 2).

The new culture has compact spike and did not separate easily even after dipping in water. Only $7.25 \%$ seeds shattered after dipping in water.

Table 1. The comparative yield performance $\left(\mathrm{kg} \mathrm{ha}^{-1}\right)$ of JI-09-21 (GI 4) over different locations

\begin{tabular}{|c|c|c|c|c|c|c|c|c|}
\hline \multirow[t]{2}{*}{ Year } & \multirow[t]{2}{*}{ Trial } & \multicolumn{2}{|c|}{ Yield $\left(\mathrm{kg} \mathrm{ha}^{-1}\right)$} & \multirow[t]{2}{*}{ IOC (\%) } & \multirow[t]{2}{*}{ Rank } & \multirow[t]{2}{*}{ S.Em. \pm} & \multirow{2}{*}{$\begin{array}{c}C D \\
(\mathrm{P}<0.05)\end{array}$} & \multirow[t]{2}{*}{ C.V. $\%$} \\
\hline & & JI-09-21 & GI-3 & & & & & \\
\hline \multicolumn{9}{|l|}{ Jagudan } \\
\hline $2010-11$ & PET & 1014 & 894 & 13.42 & $1 / 14$ & 56 & 167 & 10.80 \\
\hline 2011-12 & PET & 1078 & 948 & 13.71 & $1 / 14$ & 49 & 150 & 10.39 \\
\hline $2012-13$ & PET & 907 & 863 & 5.10 & $2 / 14$ & 51 & 155 & 9.47 \\
\hline 2013-14 & LSVT-II & 946 & 874 & 8.24 & $1 / 10$ & 52 & 155 & 11.55 \\
\hline \multirow[t]{2}{*}{ 2014-15 } & LSVT-II & 949 & 812 & 16.87 & $1 / 10$ & 50 & 148 & 11.12 \\
\hline & Mean (5) & 979 & 878 & 11.46 & - & - & - & - \\
\hline \multicolumn{9}{|c|}{ Kholwada } \\
\hline 2013-14 & LSVT-II & 878 & 769 & 14.17 & $1 / 10$ & 52 & 154 & 13.78 \\
\hline \multirow[t]{2}{*}{ 2014-15 } & LSVT-II & $852 *$ & 759 & 12.25 & $1 / 10$ & 31 & 91 & 9.56 \\
\hline & Mean (2) & 865 & 764 & 13.22 & - & - & - & - \\
\hline \multicolumn{9}{|l|}{ Deesa } \\
\hline 2014-15 & LSVT-II & 799 & 722 & 10.66 & $3 / 10$ & 73 & 215 & 14.79 \\
\hline \multicolumn{2}{|c|}{ Overall Mean (8 trials).... } & 928 & 830 & 11.78 & - & - & - & - \\
\hline \multicolumn{2}{|c|}{ Superiority over check.... } & $8 / 8$ & - & - & - & - & - & - \\
\hline
\end{tabular}

Table 2. Stability Analysis for seed yield in Isabgol

\begin{tabular}{lccc}
\hline Variety & Yi (mean seed yield $)\left(\mathrm{kg} \mathrm{plot}^{-1}\right)$ & bi(reg. coeff.) & S $_{\text {di }}$ (mean Sq. dev.) \\
\hline JI -09-21(GI 4) & 0.82 & 0.94 & 0.00 \\
GI-3 (Ch) & 0.42 & 0.80 & 0.00 \\
Mean & 0.39 & - & \\
\hline
\end{tabular}


Table 3. Comparative yield and quality attributes of JI -09-21 (GI 4)

\begin{tabular}{lcc}
\hline Character & \multicolumn{2}{c}{ Mean } \\
\cline { 2 - 3 } & JI -09-21 (GI 4) & GI 3 \\
\hline Days to flowering & 63 & 104 \\
Days to maturity & 102 & 31.3 \\
Plant height (cm) & 31.0 & 5.0 \\
No. of tillers plant ${ }^{-1}$ & 6.0 & 20.2 \\
No. of spikes plant ${ }^{-1}$ & 22.7 & 4.5 \\
Spike length (cm) & 4.7 & 76.4 \\
No. of seeds spike ${ }^{-1}$ & 80.7 & 1.542 \\
1000 grain weight (g) & 1.579 & 9.1 \\
Swelling factor $\left(\mathrm{cc} \mathrm{g}^{-1}\right)$ & 11.4 & \\
\hline
\end{tabular}

Table 4. Effect of water dipping on shattering of isabgol seed

\begin{tabular}{lcccccccc}
\hline Variety & \multicolumn{2}{l}{ Without Dipping } & H.I $\%$ & \multicolumn{3}{c}{ Dipping in Water (Average of } & four sample) \\
\cline { 2 - 5 } & $\begin{array}{c}\text { Dry wt. } \\
(\mathrm{kg})\end{array}$ & $\begin{array}{c}\text { Seed wt. } \\
(\mathrm{kg})\end{array}$ & & & $\begin{array}{c}\text { Dry wt. } \\
\text { (initial) } \\
(\mathrm{kg})\end{array}$ & $\begin{array}{c}\text { Sun dry } \\
\text { wt. } \\
(\mathrm{kg})\end{array}$ & $\begin{array}{c}\text { Seed wt. } \\
\text { after } \\
\text { threshing } \\
(\mathrm{kg})\end{array}$ & $\begin{array}{c}\text { Shattering } \\
\text { of seeds } \\
(\%)\end{array}$ \\
\hline GI 4 (JI-09-21) & 1.027 & 0.175 & 17.03 & & 0.894 & 0.731 & 0.115 & 7.25 \\
GI 3 & 0.959 & 0.158 & 16.47 & 1.038 & 0.811 & 0.037 & 70.07 \\
\hline
\end{tabular}

GI-4 recorded $89.67 \%$ less shattering than that of check variety, which revealed that Gujarat Isabgol 4 was non shattering in habit as compared to Gujarat Isabgol 3 which is prone to high seed shattering. The post dipped seed weight of GI 4,-was $0.115 \mathrm{~kg}$ threshed seeds, which was $96 \%$ higher than that of the post dipped seed yield of GI-3 (0.037 kg threshed seeds) (Table 4). Hence, Gujarat Isabgol 4 recommended for cultivation.

\section{Acknowledgments}

The authors are thankful to Prof. M.M. Patel and Prof. P.R. Patel, Assistant Research Scientist, SDAU, Kholwada and Dr. S.K. Jain, Assistant Research Scientist, SDAU, Deesa, for technical support and to conduct experiment.

\section{References}

Anonymous 2016a District wise area and production of spices crops in Gujarat State.
Directorate of Agriculture, Gujarat State, Gandhinagar.

Anonymous 2016b Spices exports go up by 15 per cent in value. Spices India. A Journal Published by Spices Board, Cochin. 1: 7.

Chandra V 1967 Studies in cultivation of Plantago ovata Forsk. Indian J. Pharm. 29: 331-332.

Prajapati D B, Patel K P \& Ravindrababu Y 2011 Gujarat Isabgol-3 a promising cultivar of Isabgol. Int. J. Forest Crop Improv. 2: 81-84.

Eberhart S A \& Russell W A 1966 Stability parameters for comparing varieties. Crop Sci. 6: 36-40.

Singh R N, Patel K V \& Desai N N 2005 Value addition through processing of Isabgol. In: Tikka S B S, Arha M D, Jaimini S N, Tajane K $\mathrm{R}$ \& Patel N B (Eds.). Abstr. National Symposium on Stress Management. 11-13 April, S. D. Agriculture University, S. K. Nagar, Gujarat (pp.147), Gujarat Society of Genetics \& Plant Breeding, S. K. Nagar. 